\title{
النوستالجيا الشعرية بين الأنا والآخر في ديوان (هذه الأنثى وطن) لأسماء الجنوبي الأني
}

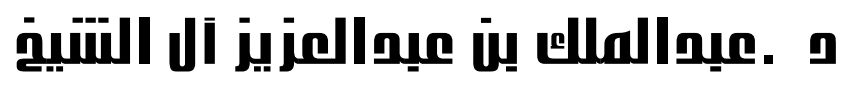

الأستاذ المساعد في قسه, الأدب بكليت اللغت العربيت

بجامعت الإماهر محمد بن سعود الإسلاميتي 
النوستالجيا الشعرية بين الأنا والآخر في ديوان (هذه الأنثى وطن) لأسماء الجنويي 
تأتي هذه الدراسةُ الموسومةُ بـــ(النوستالجيا الشعريةُ بين الأنا والآخرِ في

ديوانِ 》هذه الأنثى وطن) لأسماء الجحنوبّي)؛ في سياقِ الاستبطانِ النقديِّ المتّشح

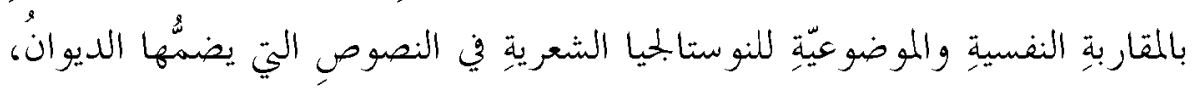

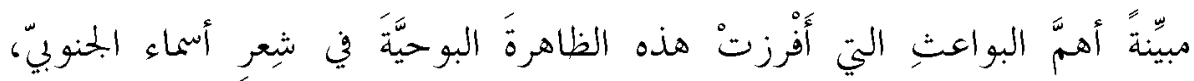

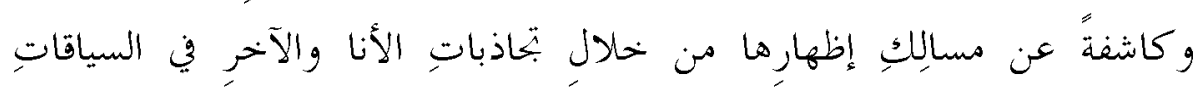
الشعريةِ، وعارضةً الفضاءاتِ التي تدورُ فيها، وبحملَ الوظائفِ التي أدَّكا.

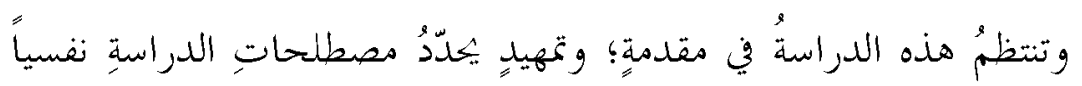

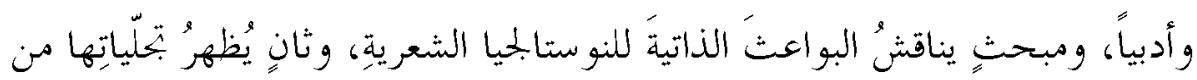

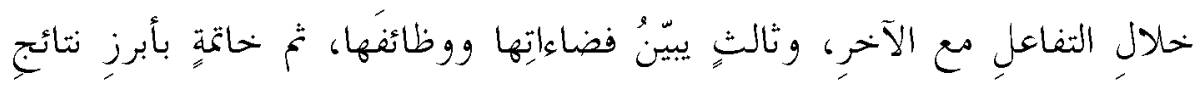
الدراسِة، وتبتِ بالمصادرِ والمراجع. وقد اتضحَ من هذه الدراسةِ طغيانُ النوستالجيا الشعريةِ على التناولِ

$$
\text { الشعريٍ في ديوان 》هذه الأنثى وطن) لأسماء الجنوبيّ. }
$$

Abstract:

The Poetic Nostalgia Between the Ego and the Other in The Collection of Poems This Woman is a Homeland by Asma Aljnobi. Author: Dr. Abdulmalik Abdulaziz Alashaykh Assistant Professor in the Department of literature in Imam Mohamed Ibn Saud Islamic University The Poetic Nostalgia Between the Ego and the Other in The Collection of Poems This Woman is a Homeland by Asma Aljnobi is a study that comes in the context of critical introspection that is coated with the psychological and the objective approach of the poetic nostalgia in the poems of this collection. It Indicates the main emissions that excreted these revelatory phenomena in Aljnobi's poems, reveals the paths of its manifestations through the interactions of the ego and the other in a poetic context, reviews the spaces that it occurs in it, and the total function that it did. 
This study contains an introduction that introduces the Psychological and literary terms. Research that discusses the selfemissions of the poetic nostalgia, second research shows the manifestations through the interactions with the other, third research indicates its spaces and functions, then a conclusion of the prominent results of the study, and then the sources and references.

It comes clear from this study that poetic nostalgia has a predominate on Aljnobi's collection of poems This Woman is a

Keywords: Nostalgia, Poetic, Ego, Other.

Homeland.

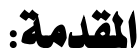

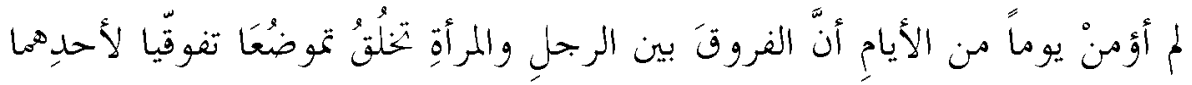

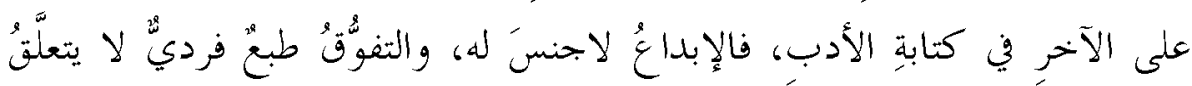

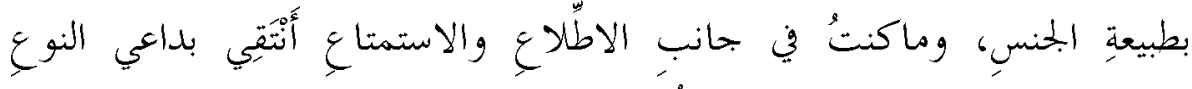

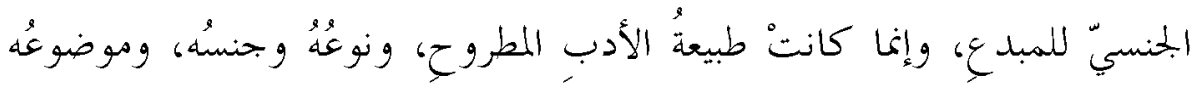

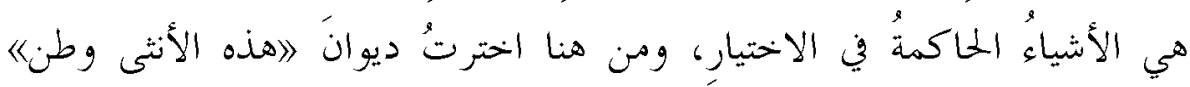

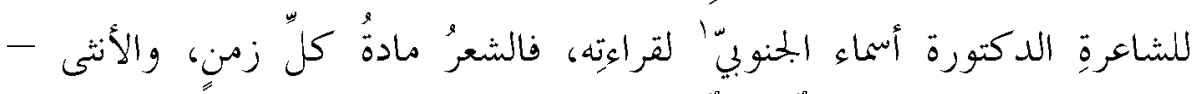

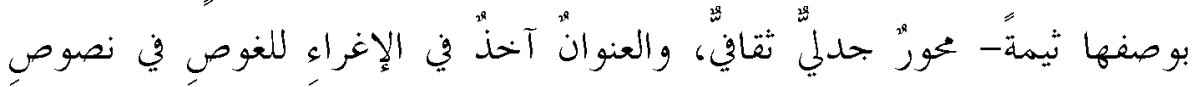

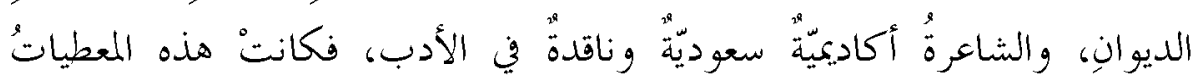

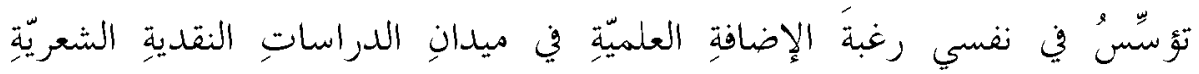

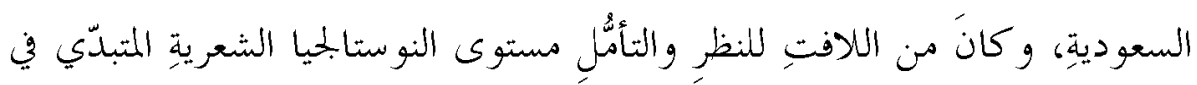

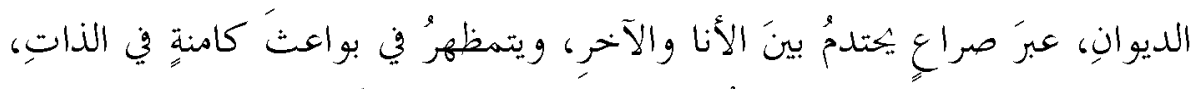

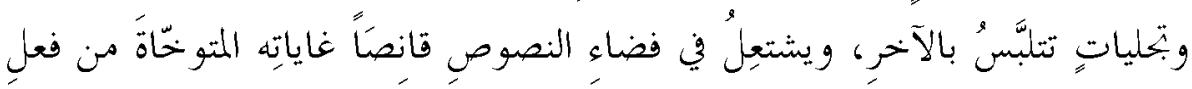

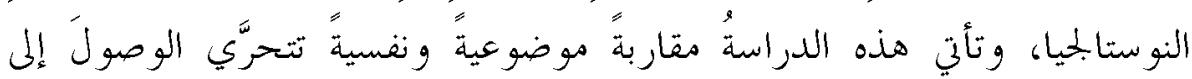

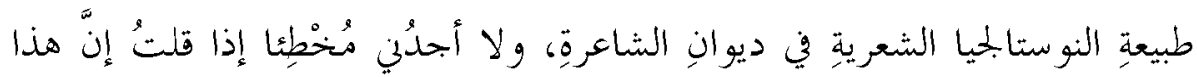

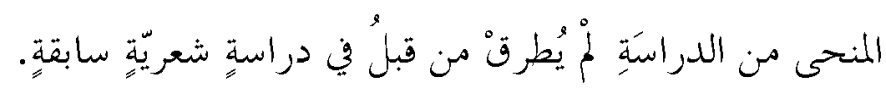


وجاءت هذه الدراسةُ في مقدمةٍ، وتمهيدٍ، وثلاثةِ مباحث؛، والتمهيدُ

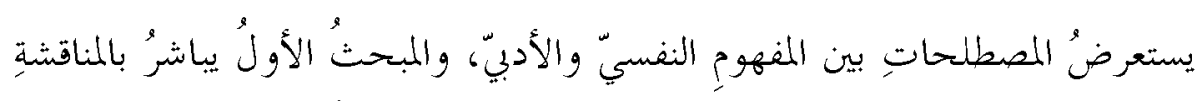

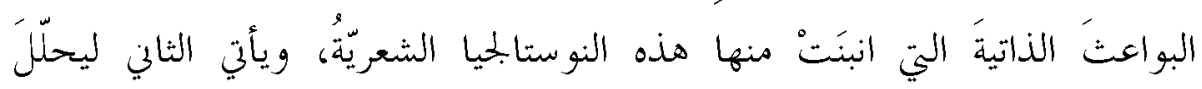

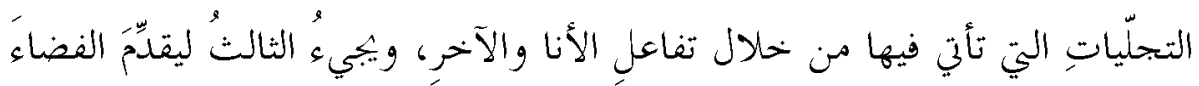

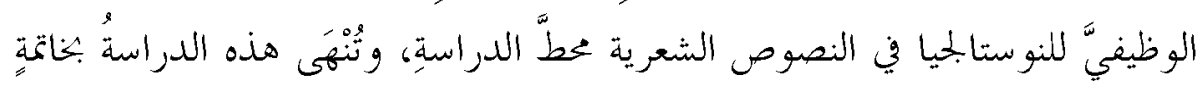
موجزةٍ لنتائجها، وثبتِ لمصادرها ومر اجعها. 


\section{التمويل}

\section{النوستالجيا والأثا والآخر بين المثهوم الثفسي والثمهوم الأدبي}

جاءَ في قاموس الموردِ: nostalgia) تُطلقُ على الحنين إلى الؤطنِ، وعلى

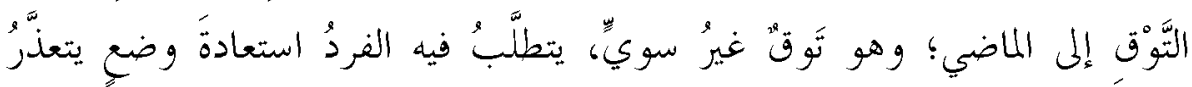

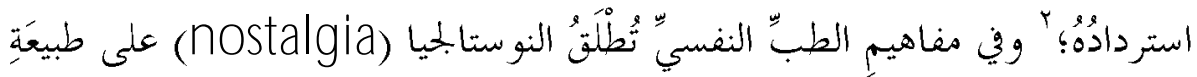

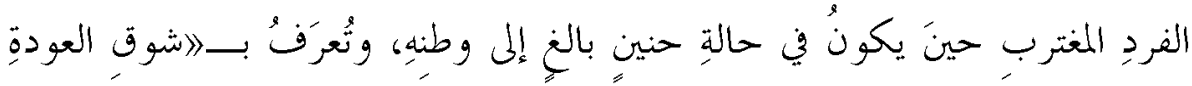

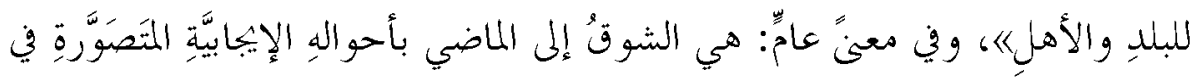

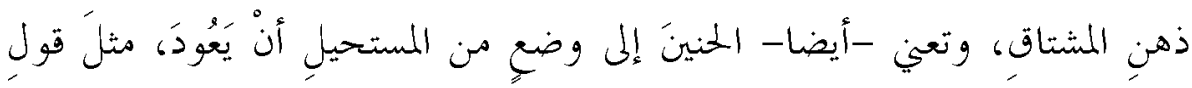

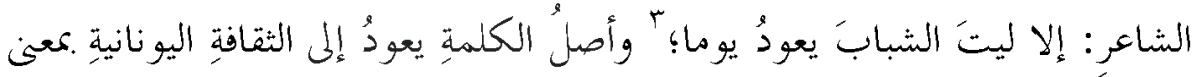

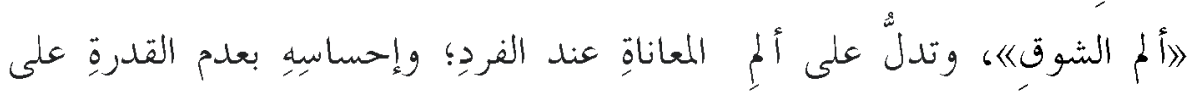
العودة لبيته وخوفِه من ذلك، وترجعُ أقدمُ التوصيفاتِ الطبيةِ لمصطلح

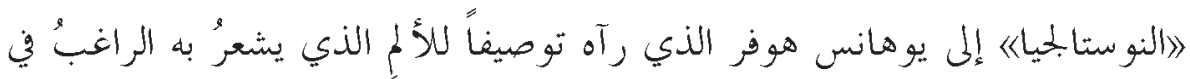
العودةِ إلى الموطنِ.

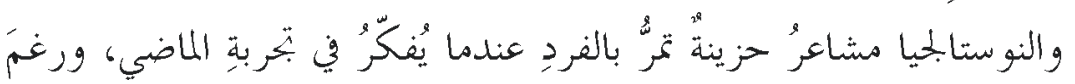

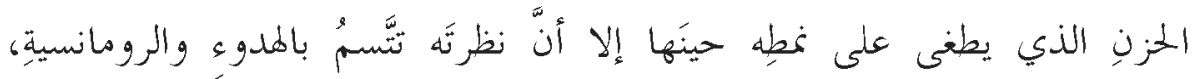

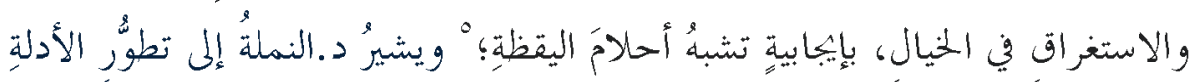

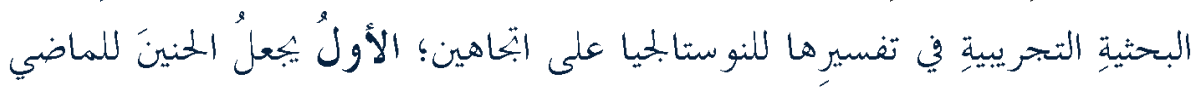

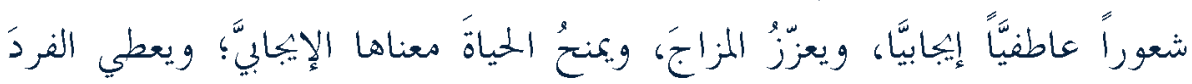

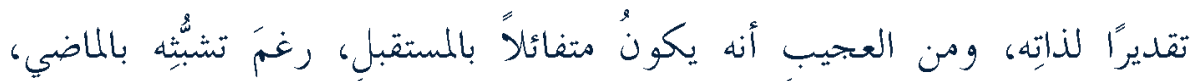

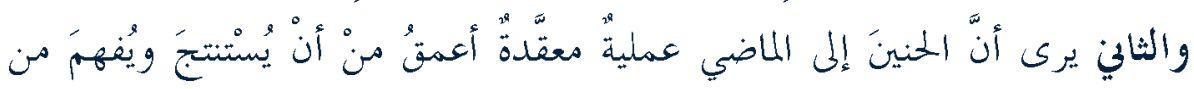

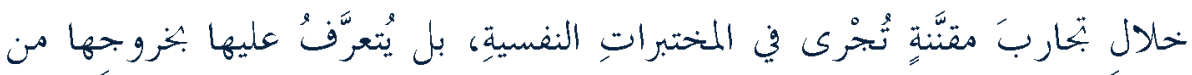
المعاملِ إلى الحياةِ اليوميةِ الطبيعيةِ للإنسانِ ومتابعةِ تصرفاتِهِ وحالاتِه المزاجيةِ في

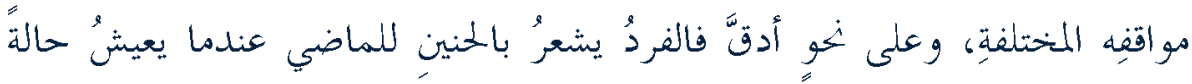




\section{النوستالجيا الشعرية بين الأنا والآخر في ديوان (هذه الأنثى وطن) لأسماء الجنوبي}

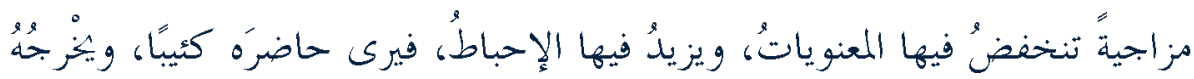

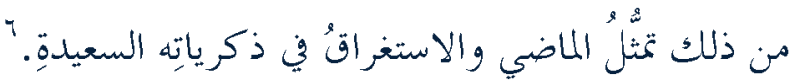

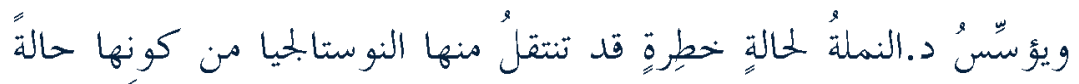

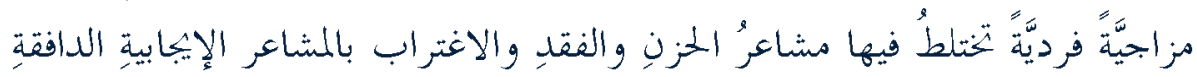

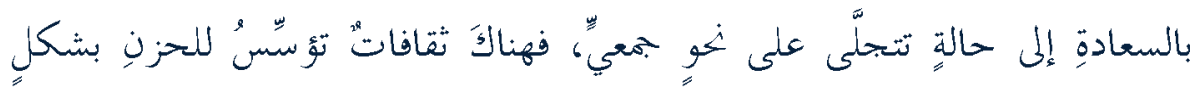

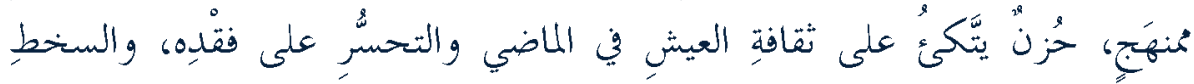

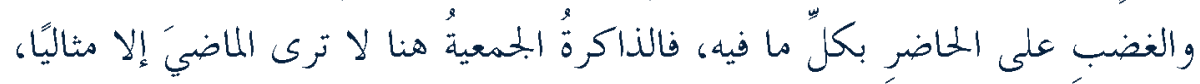

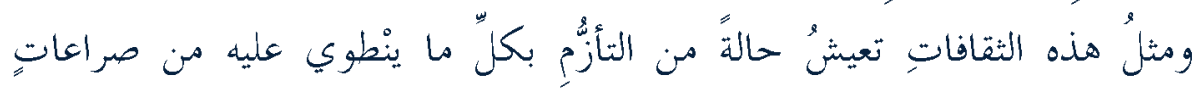

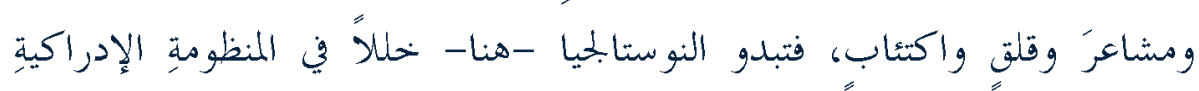

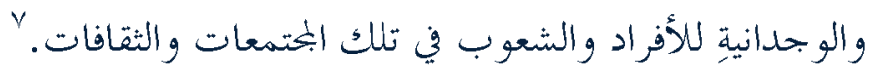
وهذهِ الطبيعةُ المرَضِيّةُ للنو ستالجميا كانتْ سبباً في اعتبارها أوَّلَ الأمر مرضًا

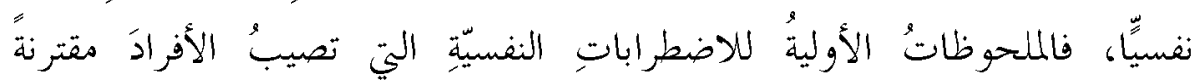
باسترجاع الذّكريات أو الاطلاع على الرسائلِ والصورِ، أو بغيرِها من أدواتِ

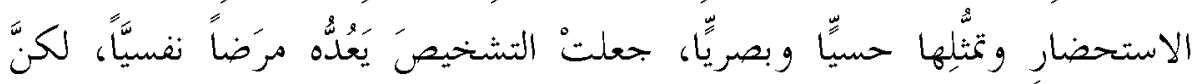

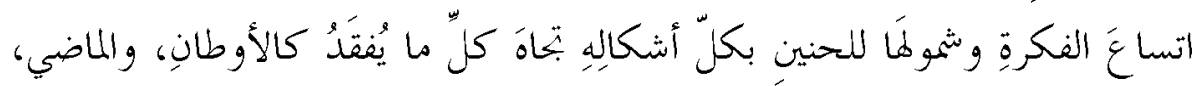

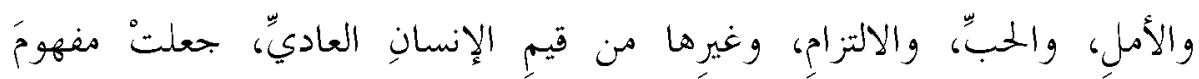

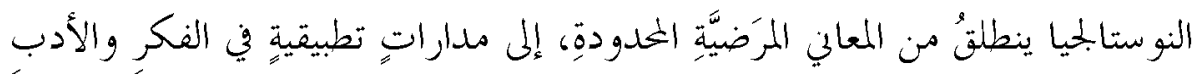

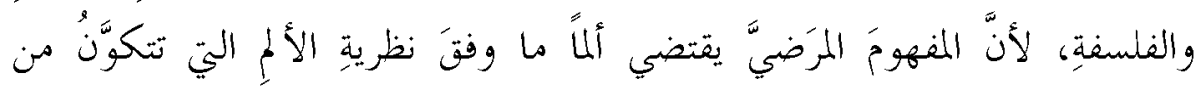

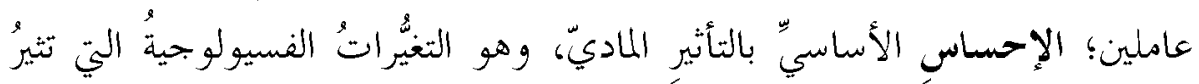

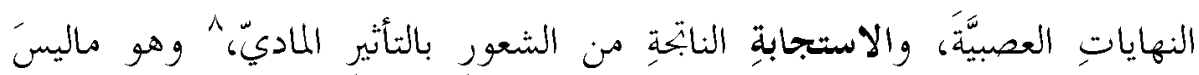
مو جودا في النو ستالجيا بمفهورِها العامَ. 


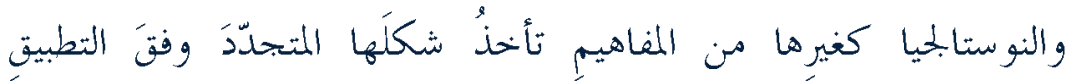

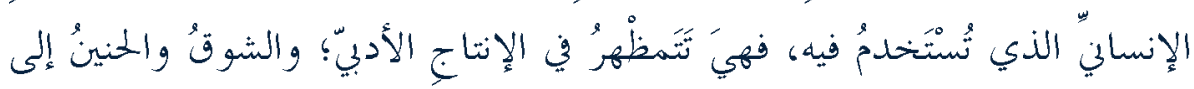
الماضي أو المفتوداتِ الإنسانية هو واحلٌ من سلو كياتٍ غير واعيةٍ تطراً على الشاعر

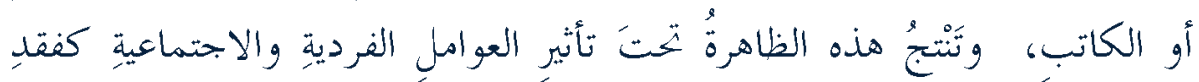

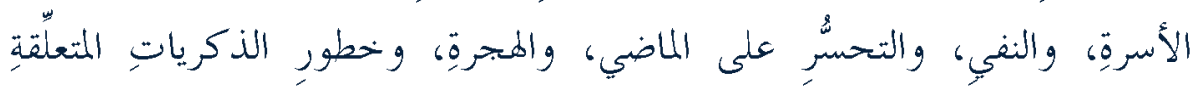

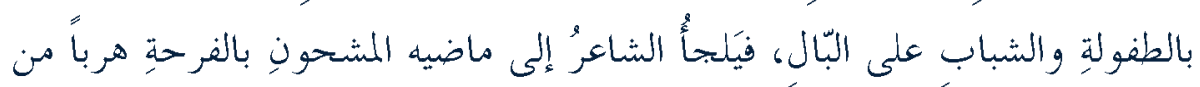
الترحة.

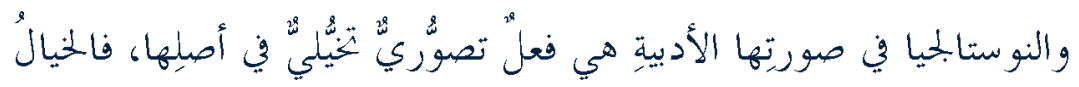

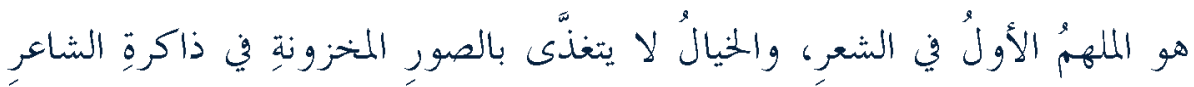

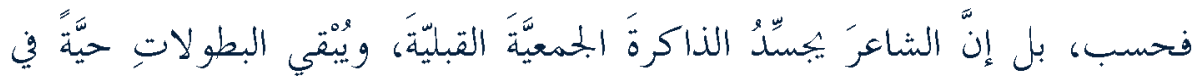
قلوب دعاصريه وعقولهم، ويكفظ إبنازات الماضي وبلأيًاه، وينقلنها إلى الأجيال 1. المبندة.

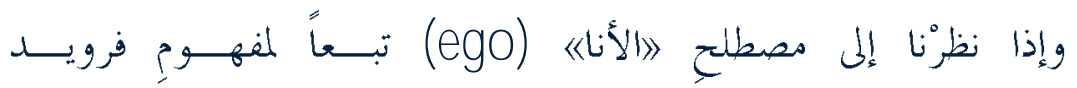

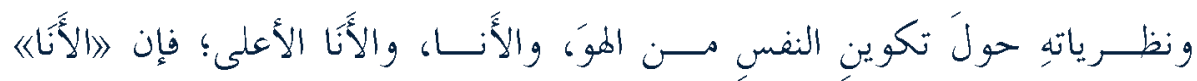

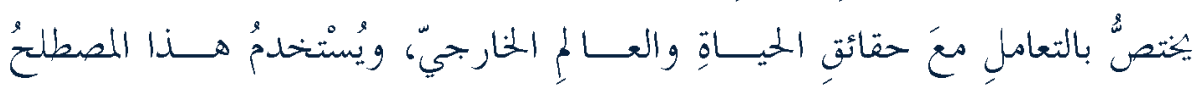

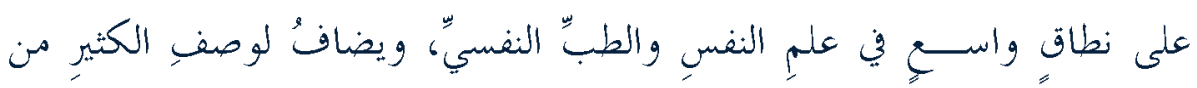

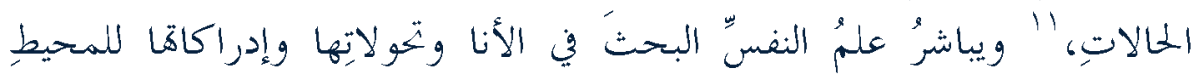

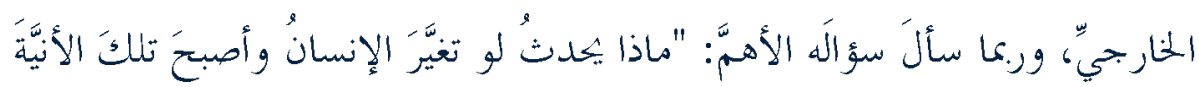

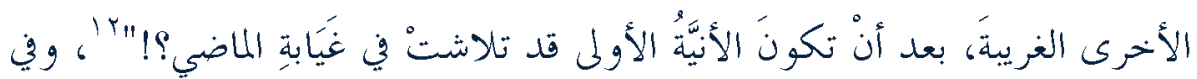

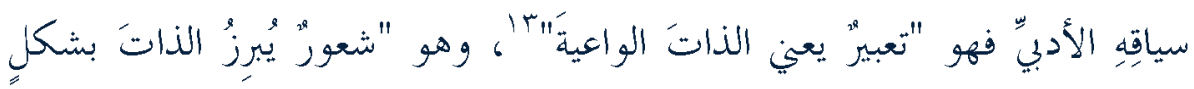

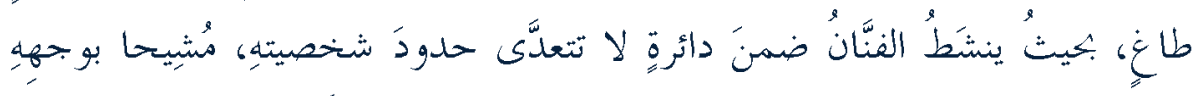

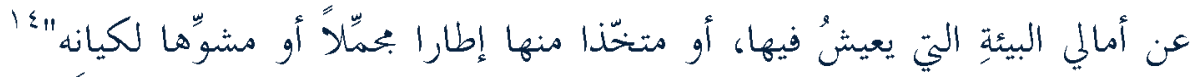

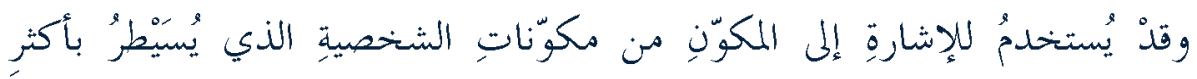




\section{النوستالجيا الشعرية بين الأنا والآخر في ديوان (هذه الأنثى وطن) لأسماء الجنويي}

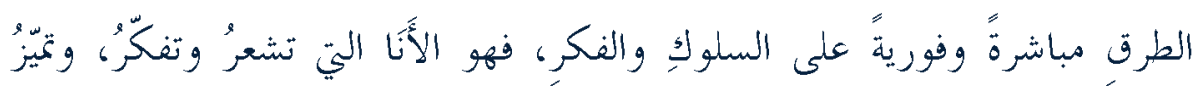

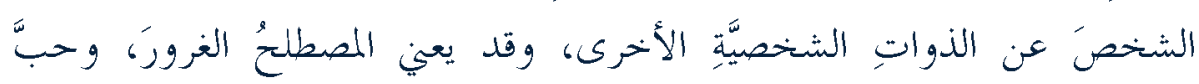

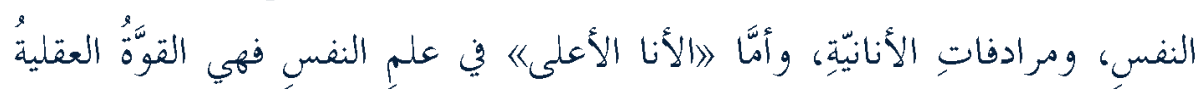

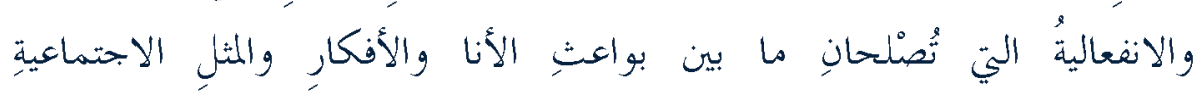

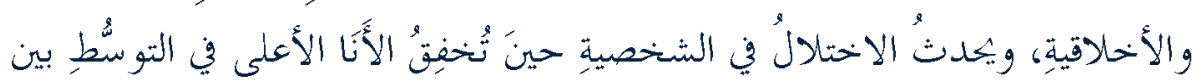

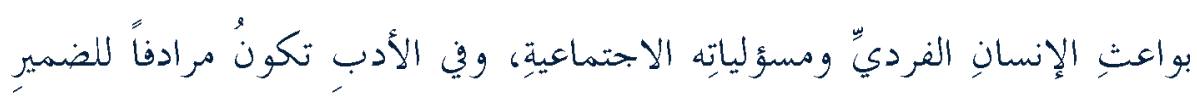
والأخلاقياتِ، أوما يُسمَّى بقبول القانونِ الأخلاقيّ. 10

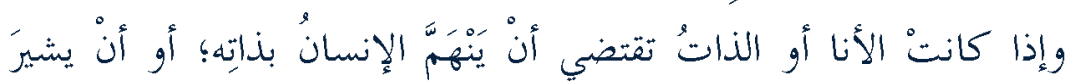

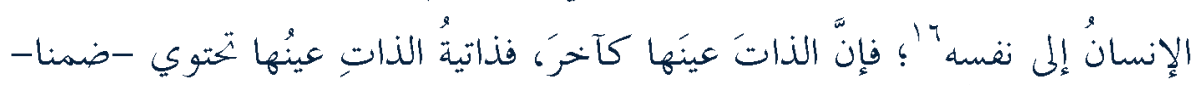

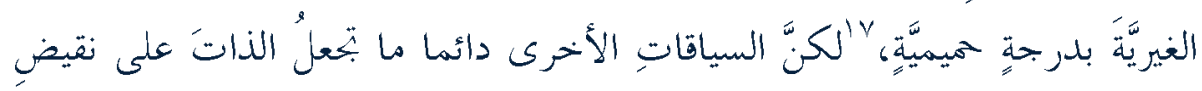

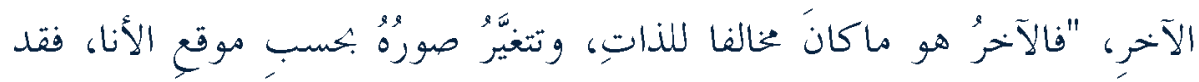

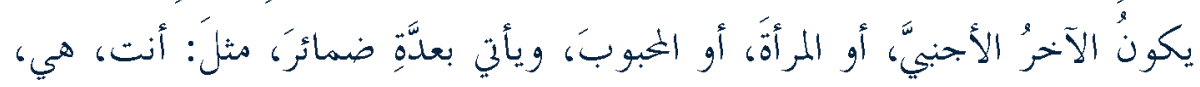

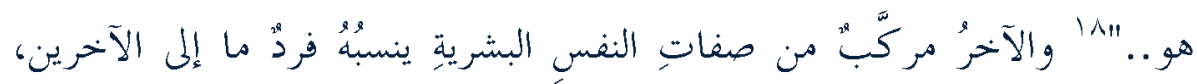

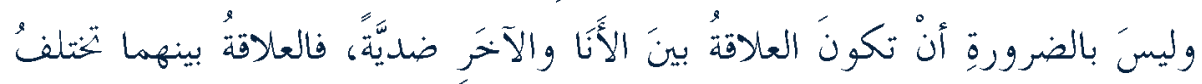

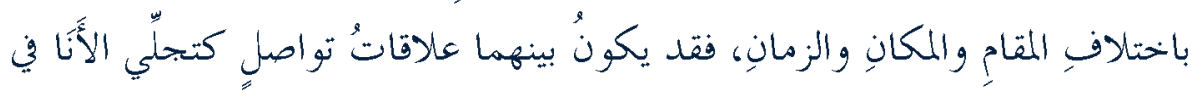
ذاتِها، أو انفصال كالاغترابِ النفسيّ، أوتنافرٍ كما بين الشرق و والغربِ. 


\section{المابتشث الأول

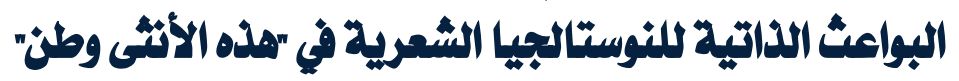

تنبعثُ النوستالجيا في الشعرِ من خلال التغاعلاتِ الوجدانيةِ والذهنيةِ من

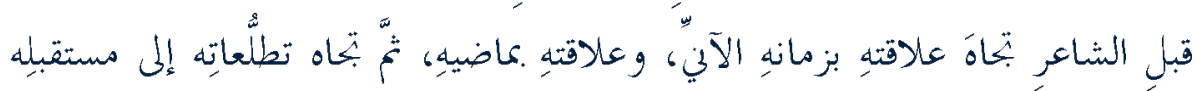

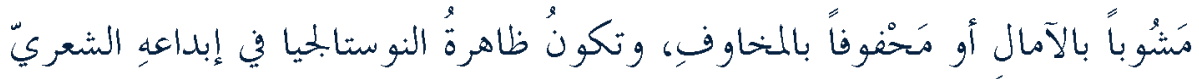

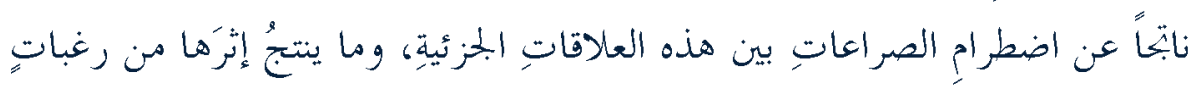

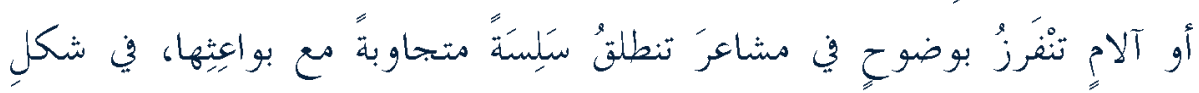

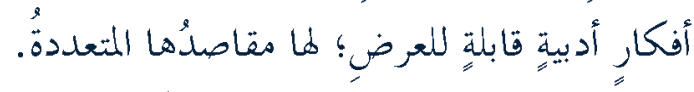

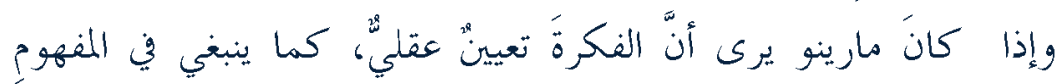

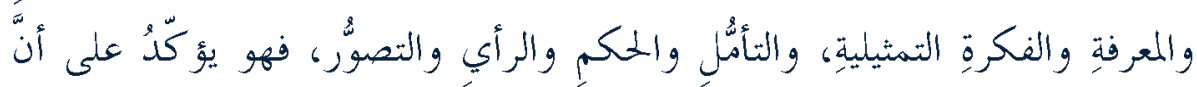

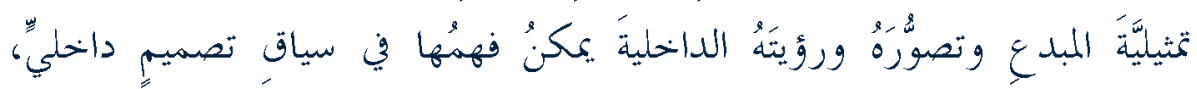

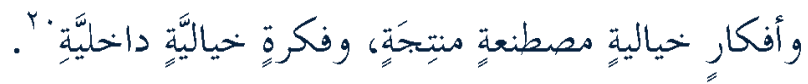

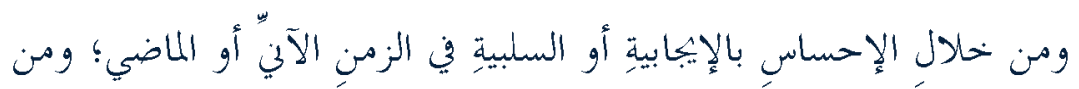

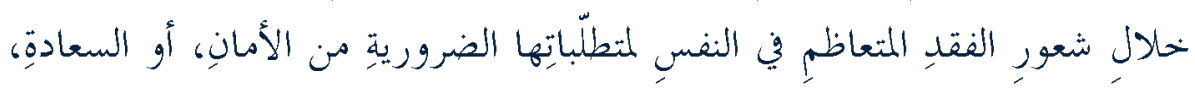

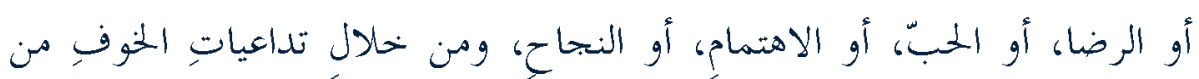

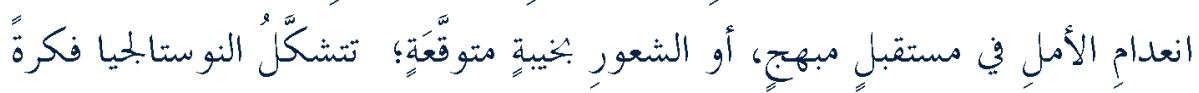

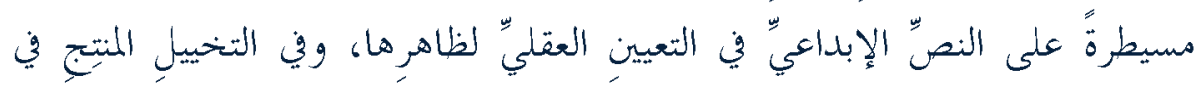
جوهر ها.

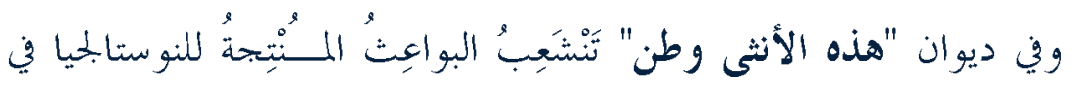
شعر أسماء الجنوبيّ وفقَ البواعثِ الثلاثةِّ: أَ- بواعث استعادية "رغبة العودة": تُعََّفُ الاستعادةُ بأنَّها: "الإعادةُ أو الإحياءُ،

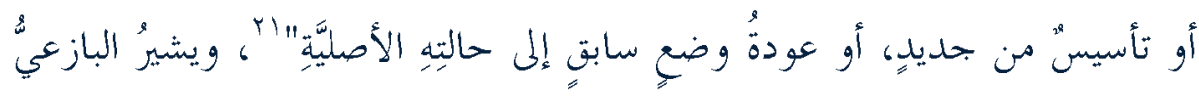

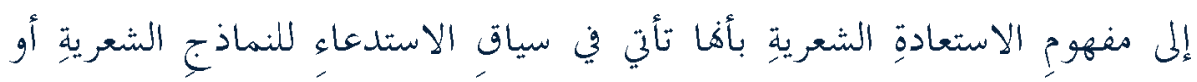




\section{النوستالجيا الشعرية بين الأنا والآخر في ديوان (هذه الأنثى وطن) لأسماء الجنويي}

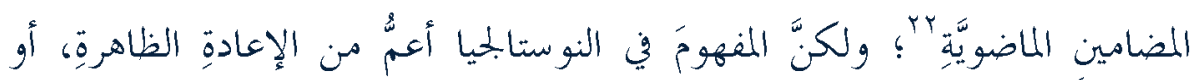

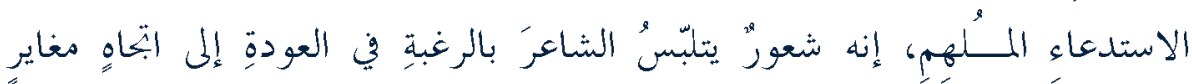

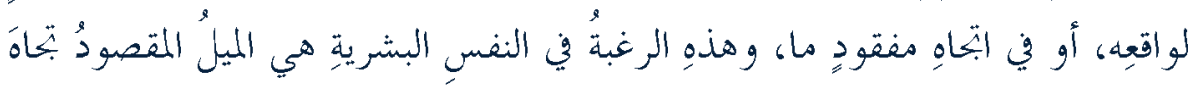

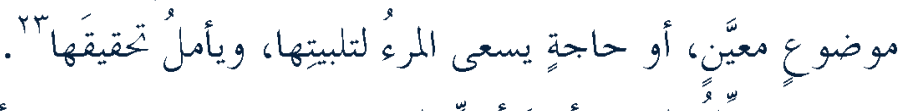

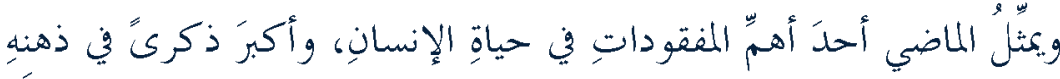

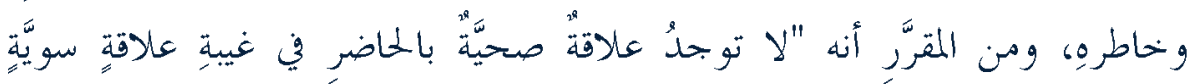

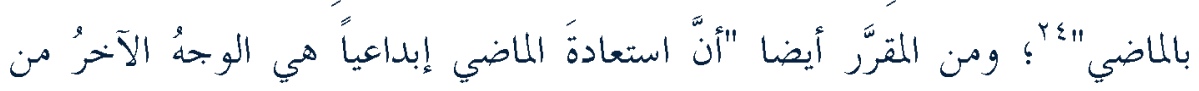

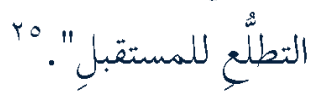
وأولُ ما يبادرُنا من البواعثِ الذاتيةِ الاستعاديةِ في نوستالجيا الماضي في

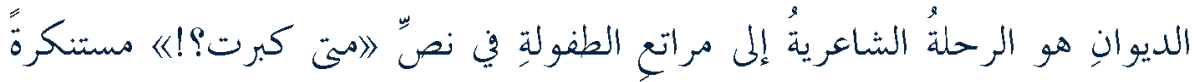

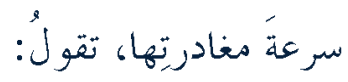

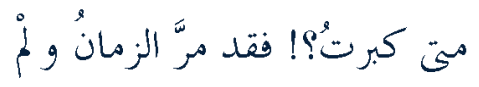
أظفرْ بلحظةِ صدق صوتُها انفعلا

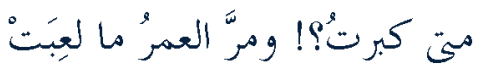

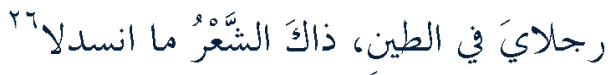

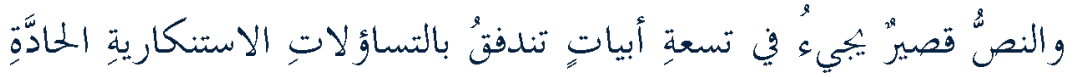

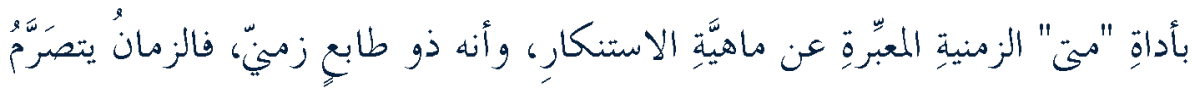

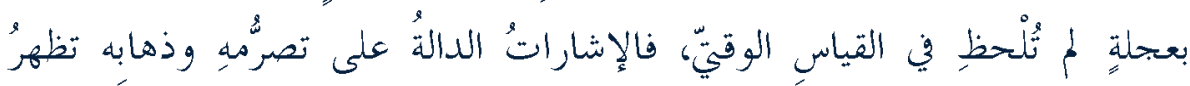

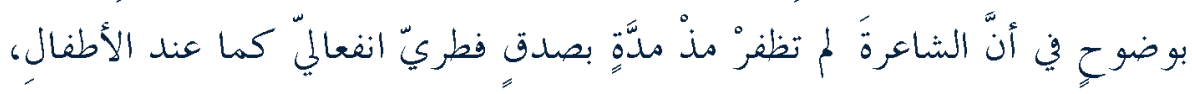

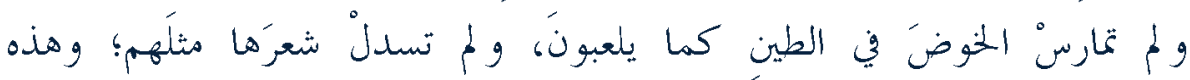

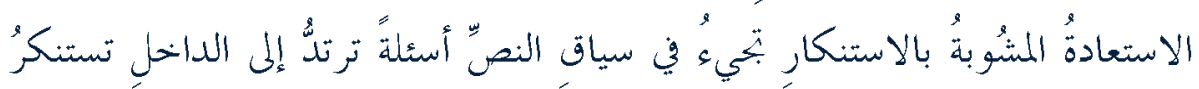

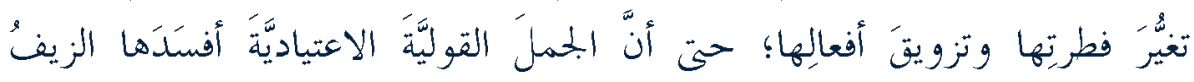


والتضليل، والخيالُ في هذه القصيدةٍ "قادر" على تكوينٍ صورةٍ ذهنيَّةٍ عن أشياءً

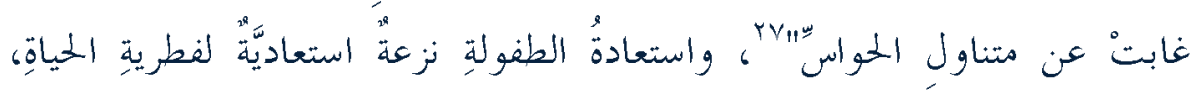

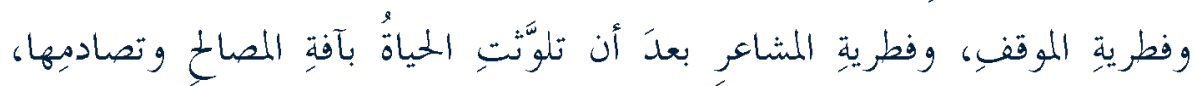

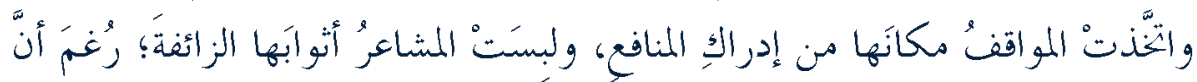

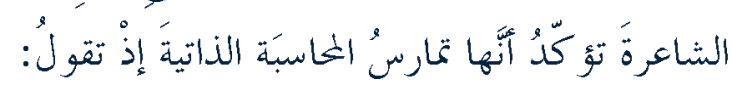

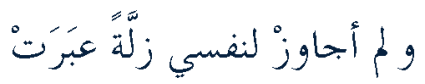

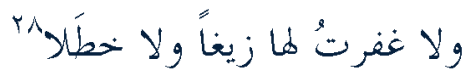

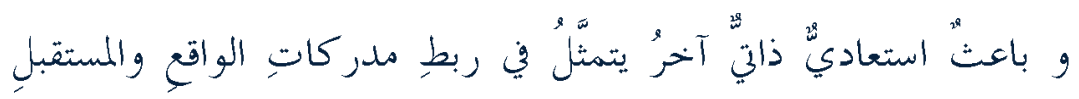

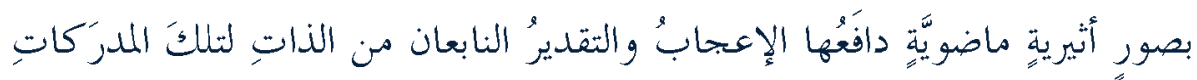

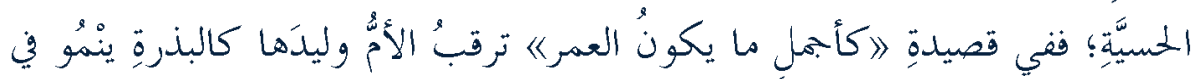

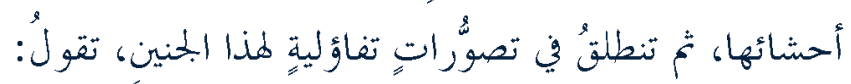

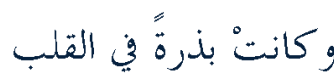

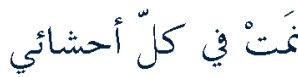
أراقبُ فجرَ مقدِدِه

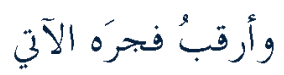
وحينَ تكونُ يا ولَّبري

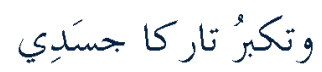
وترحل مُعْ سينّ العمرْ

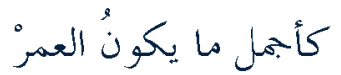

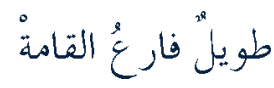

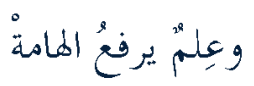
وورجه لو روأتهه الشمسُو ما غرُبَتْ 


$$
\begin{aligned}
& \text { وعين }
\end{aligned}
$$

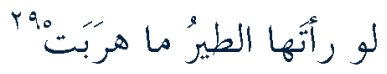

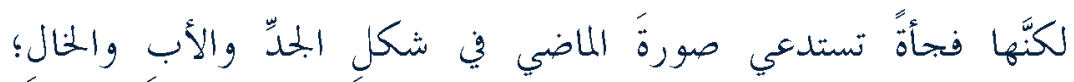

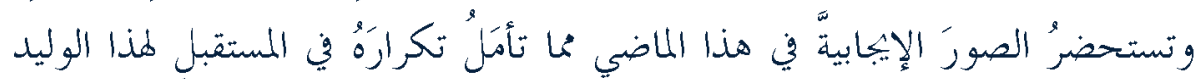

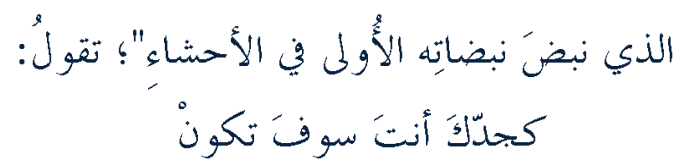

$$
\begin{aligned}
& \text { كهيئتِِ } \\
& \text { كلحيتهِ، } \\
& \text { وتتلو الآيَ والقر آنَ } \\
& \text { في الأركانِ .. في المسجدْا } \\
& \text { وقلبُك وافر" غض كُّ كقلب أبيك } \\
& \text { وروحُك تمالكُ الدنيا } \\
& \text { كروح أبياكْ! } \\
& \text { ومن خال خُخِْ الطيبة } \\
& \text { خُخ العينين }
\end{aligned}
$$

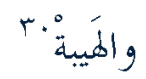

وهنا نرى الشاعرةَ مرتبطةً مكاضيها القريب البعيدِ في صوره الجميلةِ المعبّرةٍ

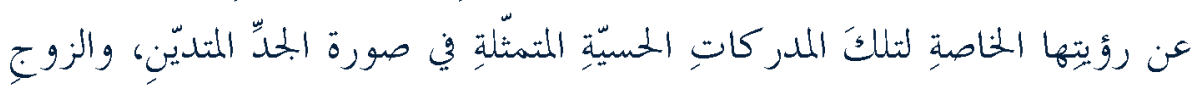

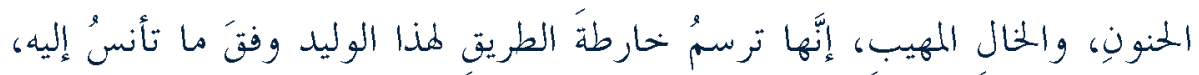

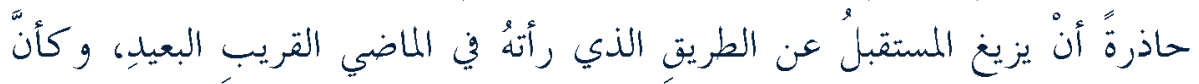

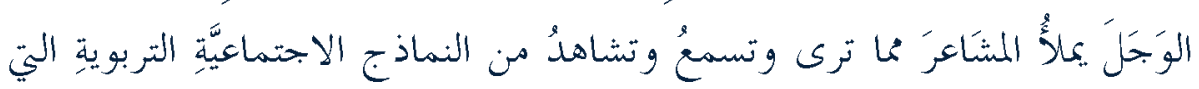

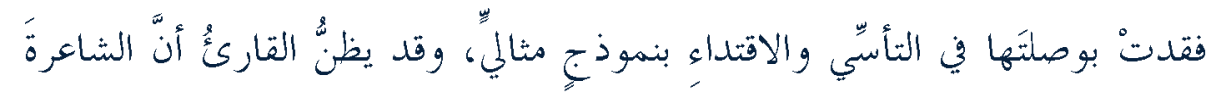




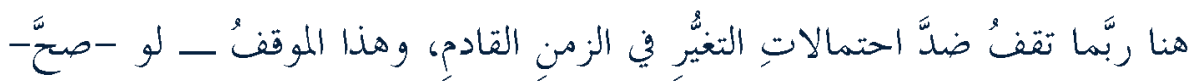

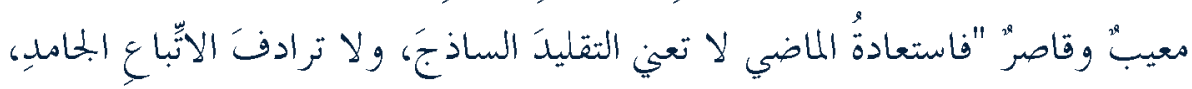

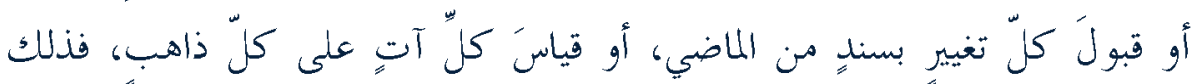

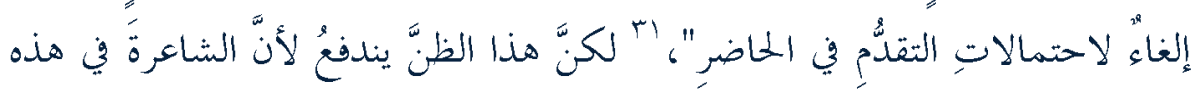

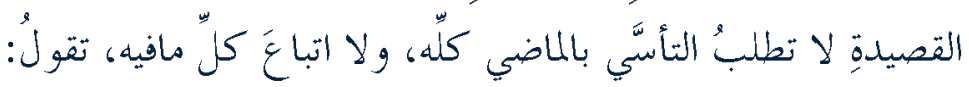

$$
\begin{aligned}
& \text { و ومثلي } \\
& \text { لا تقلْ شعر } \\
& \text { ولا ترسمْه بالقلم } \\
& \text { ولكن: كن: جوادَ الروح } \\
& \text { قلبا صيغَ فيه دمي ترن }
\end{aligned}
$$

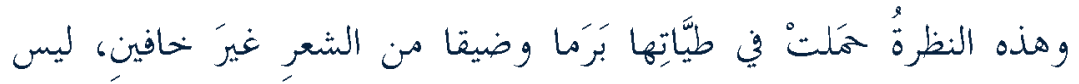

$$
\text { الكشفن عن أسبابهما موضوغَنا. }
$$

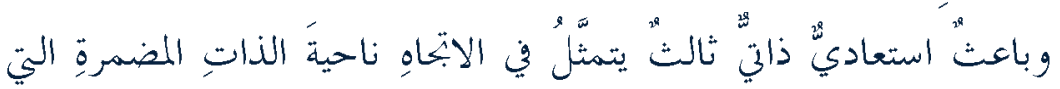

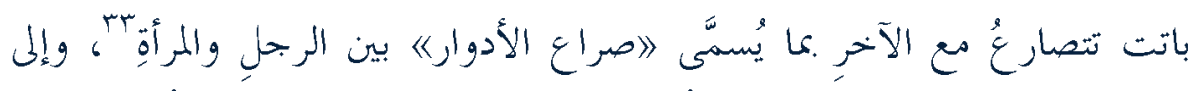

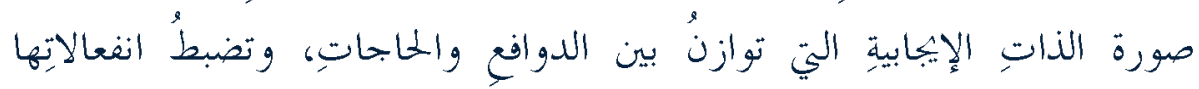

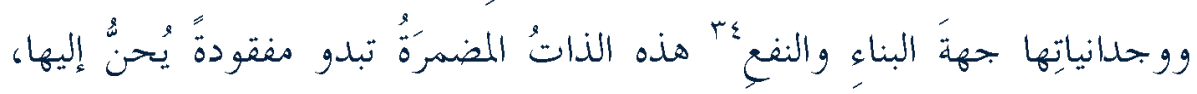

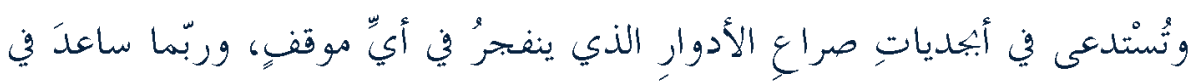

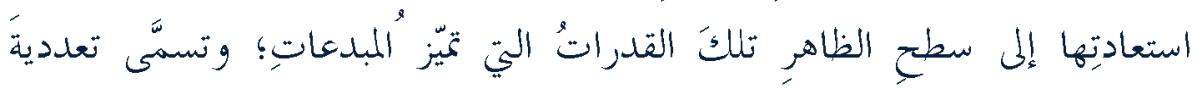

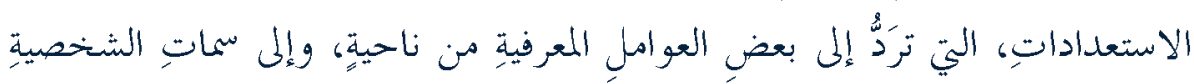

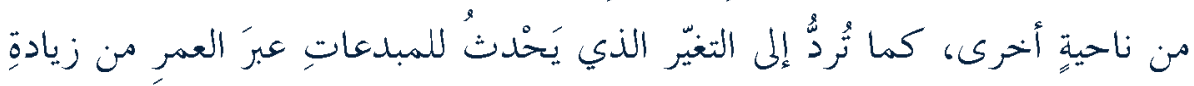

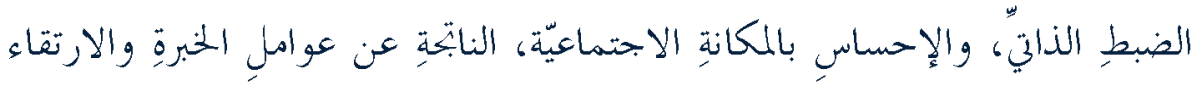

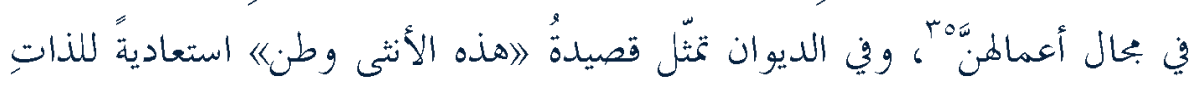
المضمرةقة تقول: 


$$
\begin{aligned}
& \text { هذه الأنتى وطن } \\
& \text { صوها آس } \\
& \text { وللصوتِ شجن } \\
& \text { هذهِ الأنثى وطنْ } \\
& \text { ربّما تبين حصوناً للزمن النتي وطن } \\
& \text { ربما تأسرُ التأريخخ، أو تحضُنهُ }
\end{aligned}
$$

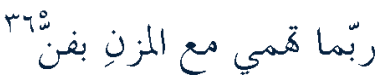

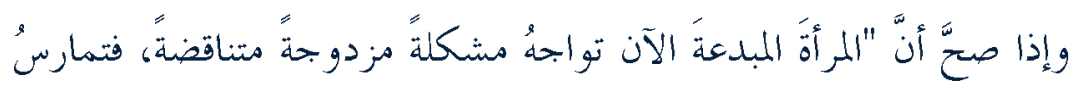

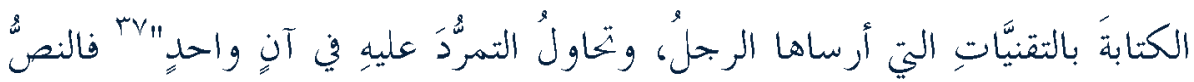

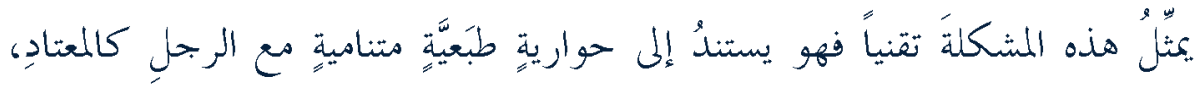

$$
\begin{aligned}
& \text { فهي تسائلُهُ في إنكار: } \\
& \text { هلْ رأتْ عيناكَ في هذا الزمنْ } \\
& \text { من يكيلز الخحنَّ ألوانا، } \\
& \text { ويعطي مخلصا.. }
\end{aligned}
$$

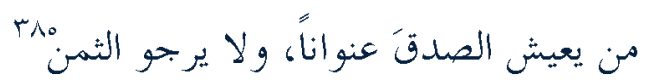

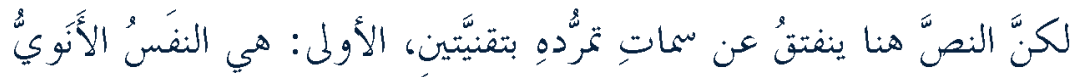

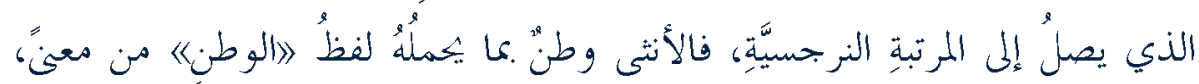

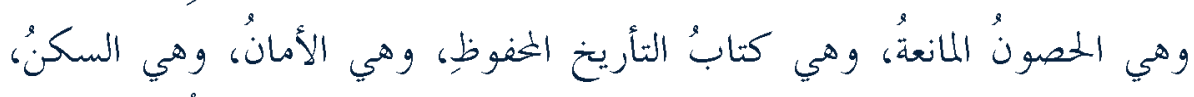

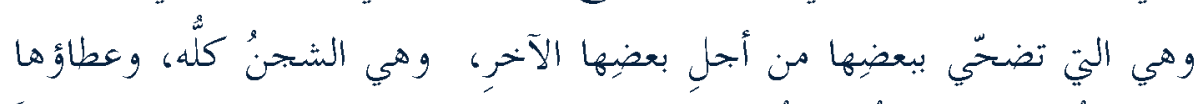

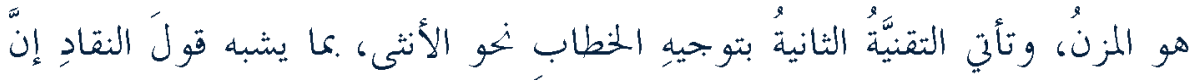

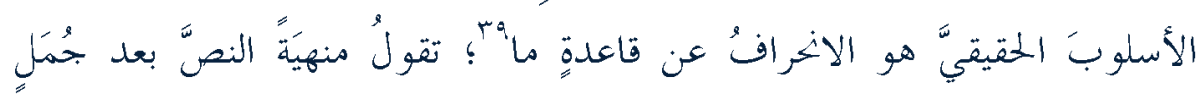

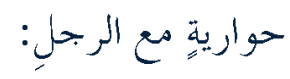




$$
\begin{aligned}
& \text { هذه الأنثى وطن: } \\
& \text { هل تُرى تدري؟! }
\end{aligned}
$$

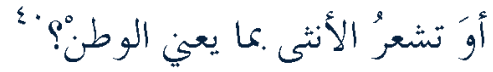

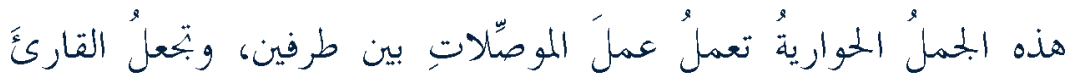

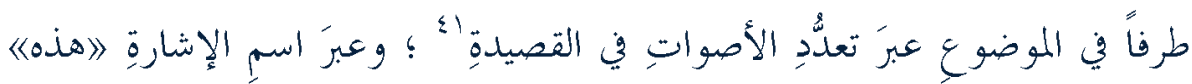

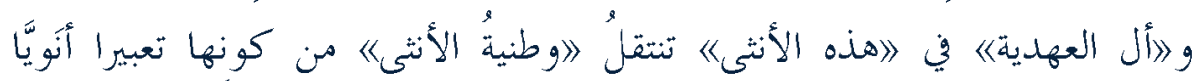

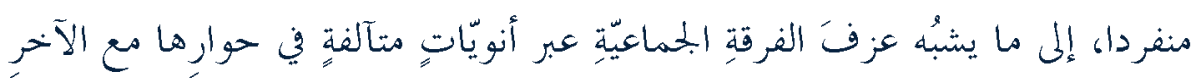

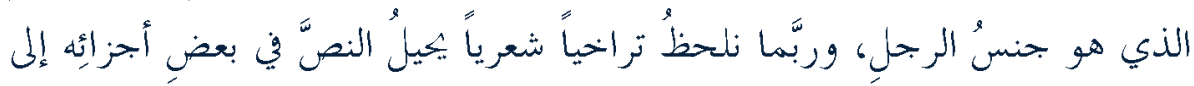

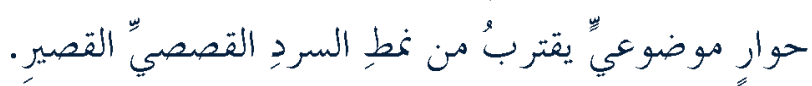

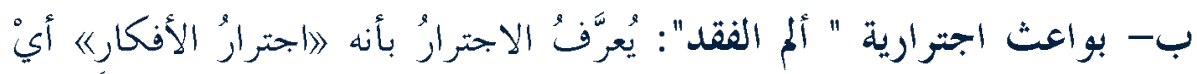

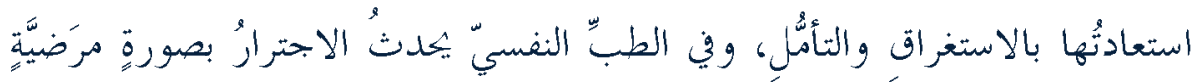

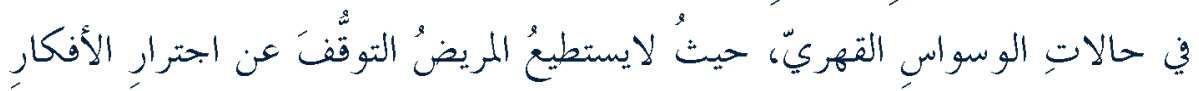

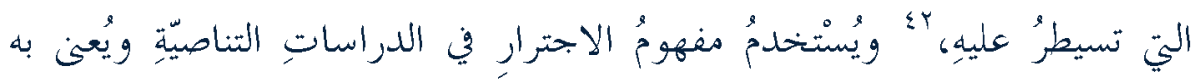

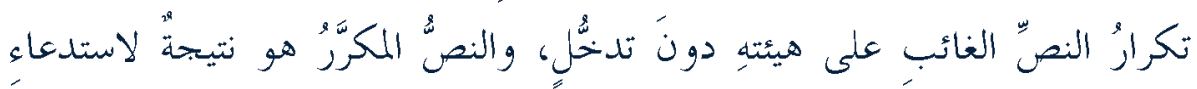

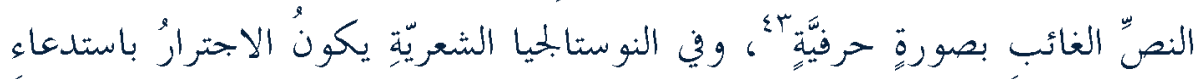

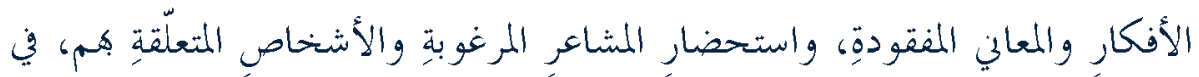

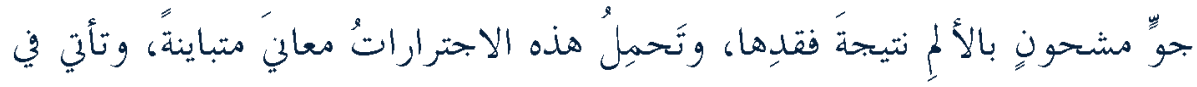
سياق أسباب متنوِعةِ.

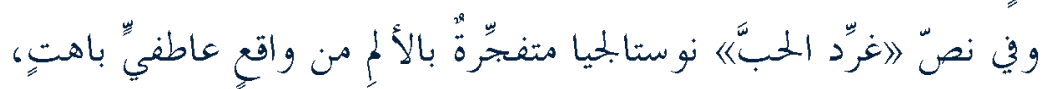

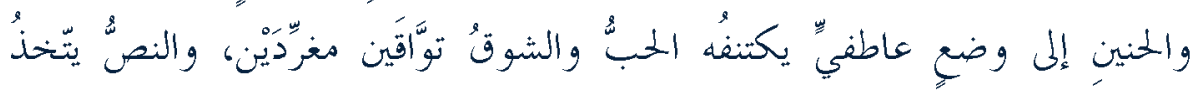

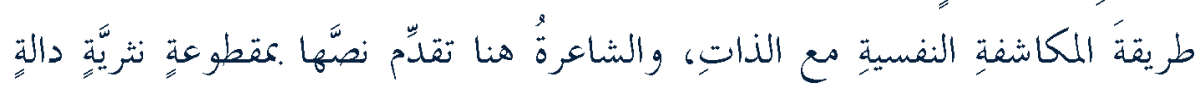

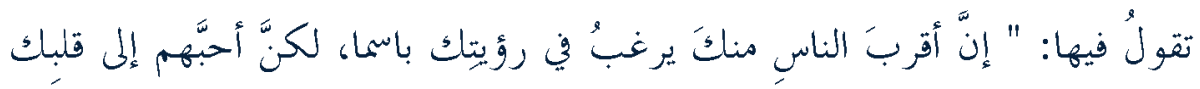

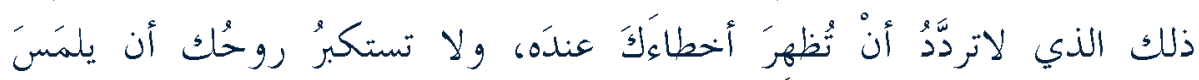




\section{النوستالجيا الشعرية بين الأنا والآخر في ديوان (هذه الأنثى وطن) لأسماء الجنوبي}

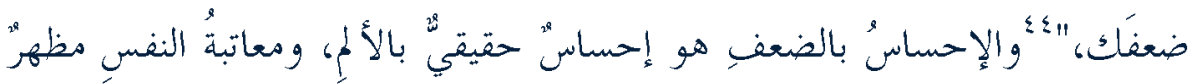

للاستشفاء والمقاومةِ الذاتيةِ، تقول:

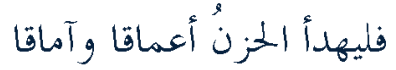

ولتنشري السعدَ فوقَ الوجهِ برَّاقا

وما عليها إذا كانتْ وُوَاريةً

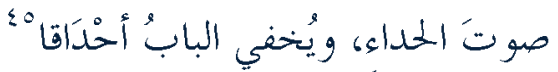

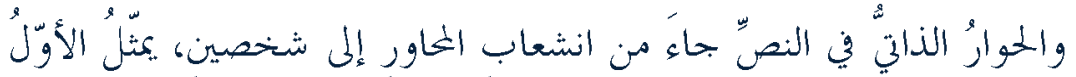

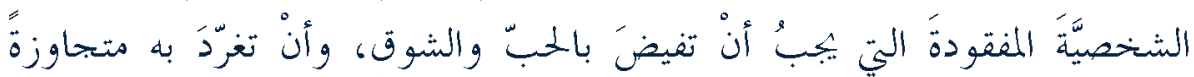

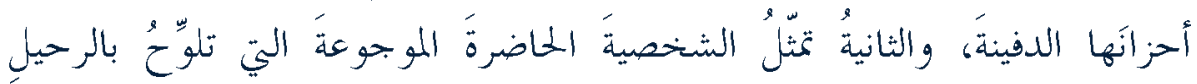

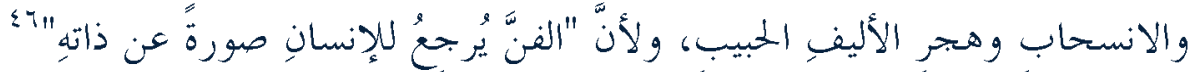

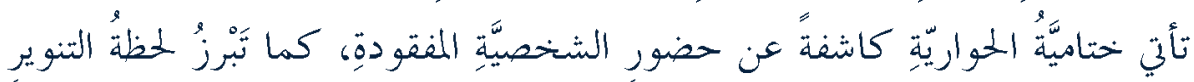

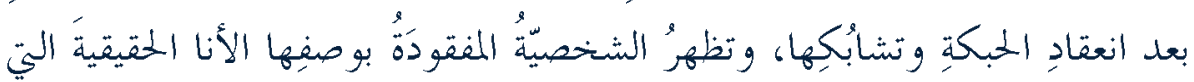

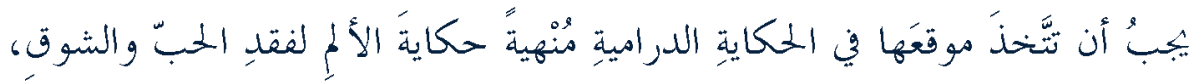

$$
\begin{aligned}
& \text { تقول في لخنِ طربيِّ شائقِ } \\
& \text { قِفي هناك، ولا تستأسدي لغة } \\
& \text { بل نمّتي الشعرَ ألواناً وعُشََّّاقا } \\
& \text { ولوّي الحبَّ بالآمال راجيةً }
\end{aligned}
$$

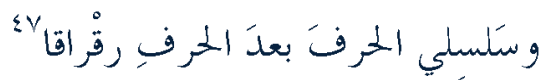

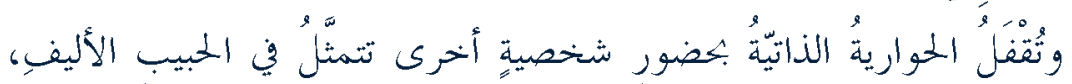

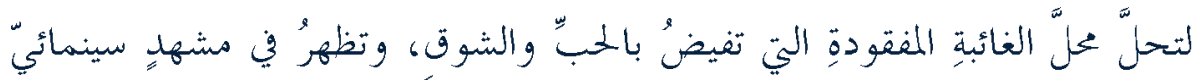

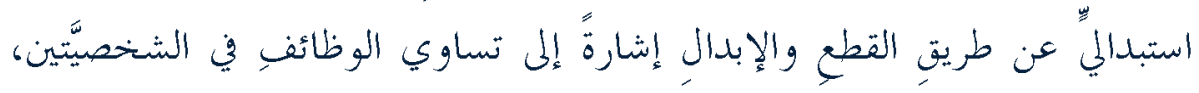

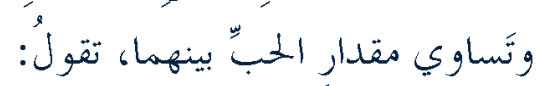




$$
\text { با لا ساكنا في فؤادي سهمَ أوردَتي }
$$

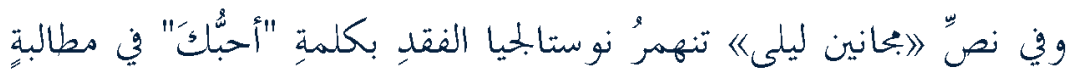

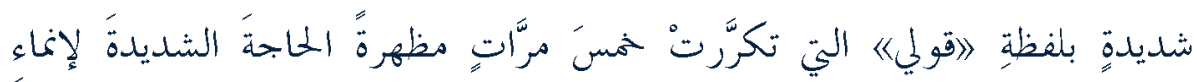

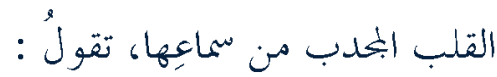
قولي أحبُّكُ رغم أنفب الشاعرِ رغم المأسي وانكسارِ الحاضرِ

$$
\text { قولي أحبُّك }
$$

$$
\begin{aligned}
& \text { قولي! فقد طالَ الحديث ُمدمعي } \\
& \text { وبكى فؤادي }
\end{aligned}
$$

$$
\begin{aligned}
& \text { وانتشى لكِ ناظري } \\
& \text { قولي حديثا! عبرةً مضريَّةً } \\
& \text { قولي ! بولي }
\end{aligned}
$$

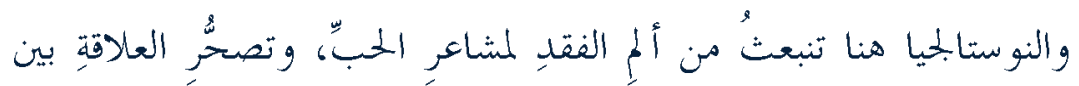

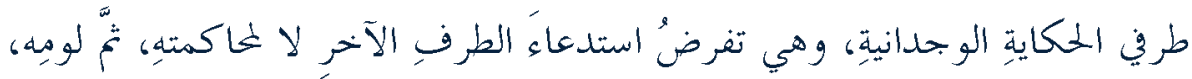

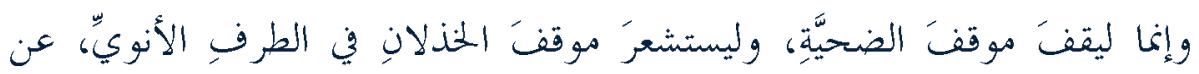

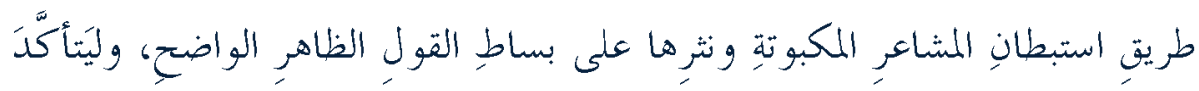

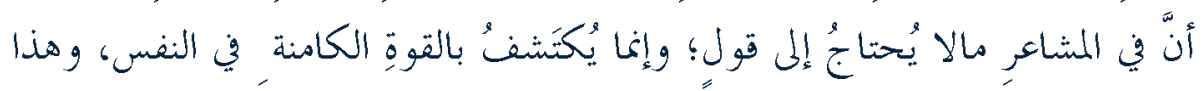




\section{النوستالجيا الشعرية بين الأنا والآخر في ديوان (هذه الأنثى وطن) لأسماء الجنويي}

يعيدُنا إلى المفهوم الفلسفيّ للنفس المدركِِ التي تتماثل فيها الحواسهُ في الإدراكِِ عبرَ

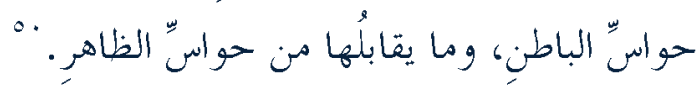

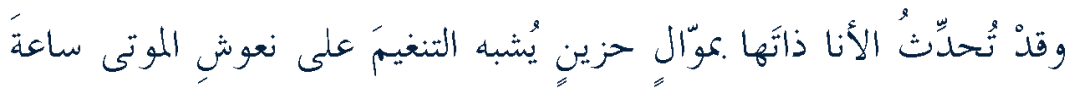

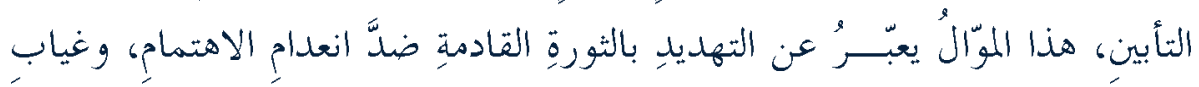

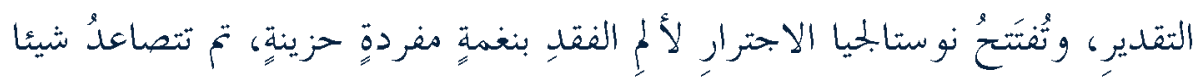

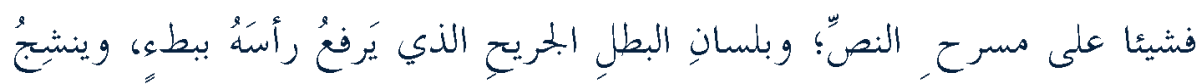

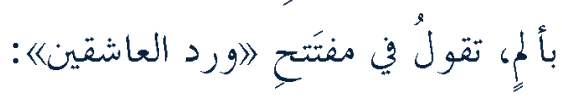
ورحلi لا قلبي إليكتُ يشلُّني ! Uั و لمُيؤخذْ بأشواق السنينْ

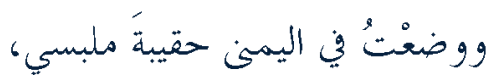

$$
\begin{aligned}
& \text { وحملت في الأخرى وصمع }
\end{aligned}
$$

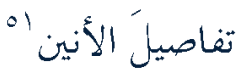

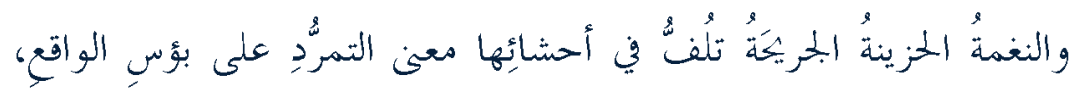

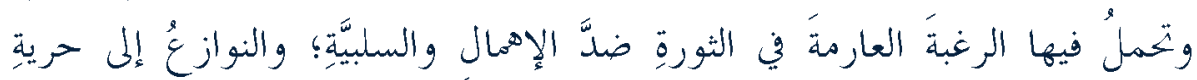

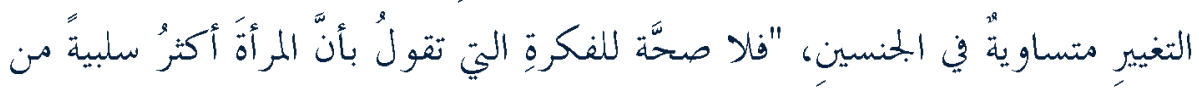

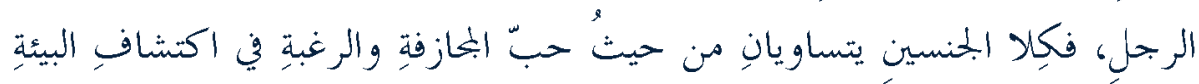

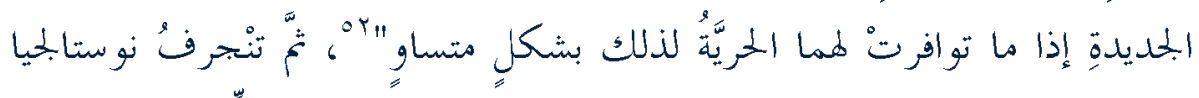

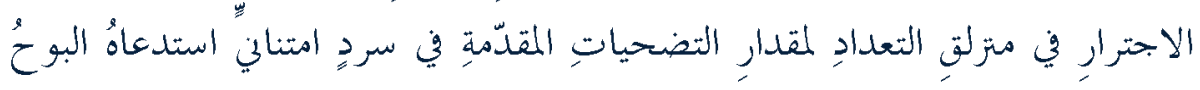

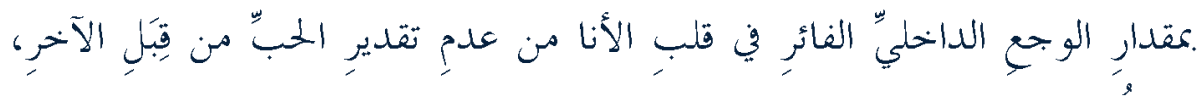
تقول: 


$$
\begin{aligned}
& \text { وكأني } \\
& \text { لم أقتر فن حسّا } \\
& \text { و لم أشعرّ بهِكا } \\
& \text { ? } \\
& \text { زهرَ الياسمين } \\
& \text { وكانَّن } \\
& \text { ما كنت' منذُ ولادنتي } \\
& \text { أرنو إليه، و وخافتيْ } \\
& \text { يككي لهُ الأشواقَ }
\end{aligned}
$$

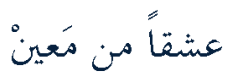

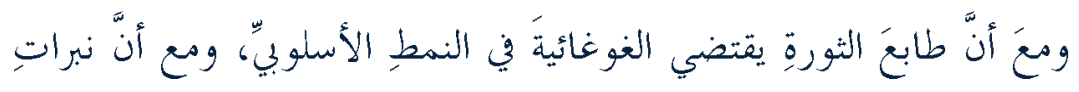

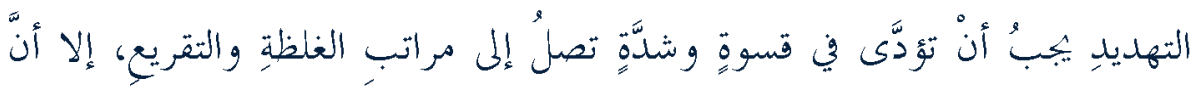

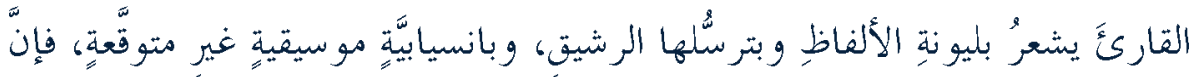

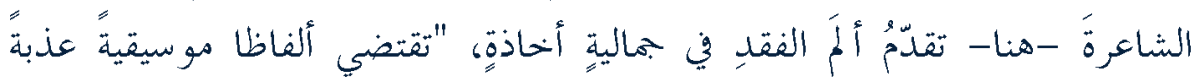

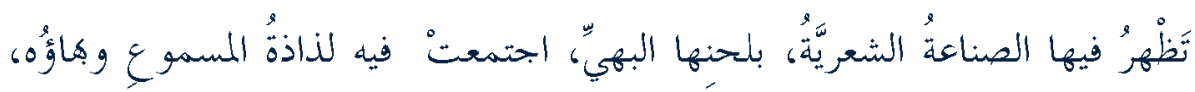

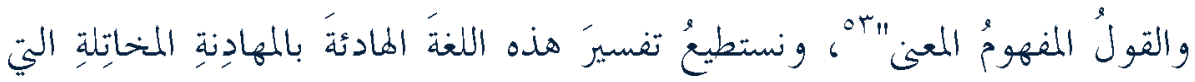

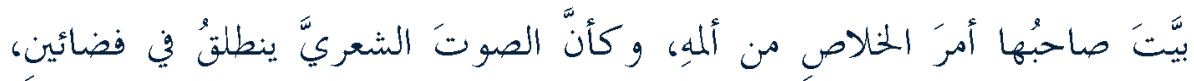

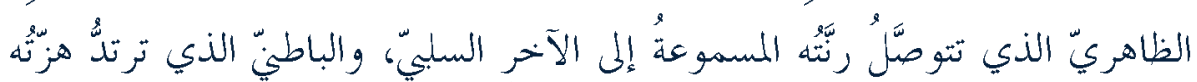

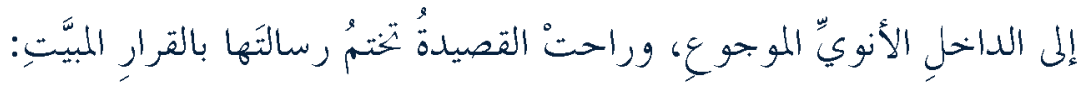

$$
\begin{aligned}
& \text { ور حلن }
\end{aligned}
$$

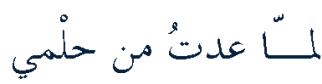

$$
\begin{aligned}
& \text { ومن صميت المبين }
\end{aligned}
$$

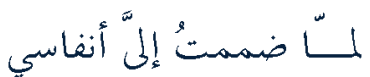




$$
\text { ونزّى خاطري }
$$

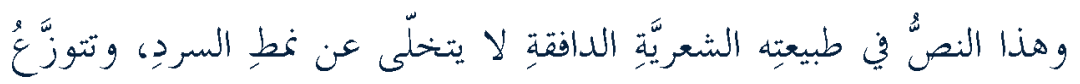

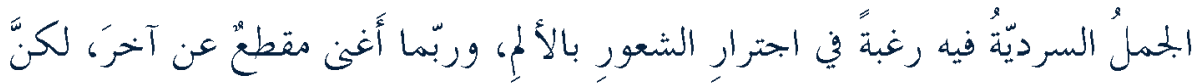

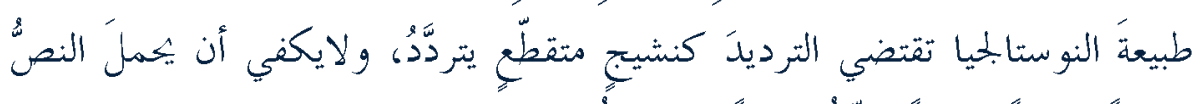

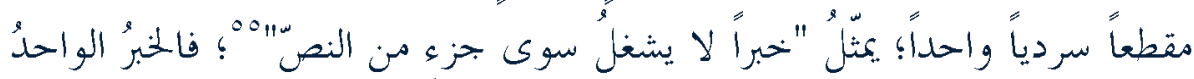

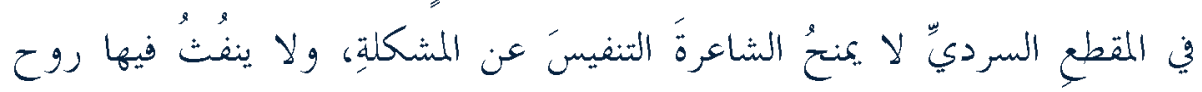
الثتابع الحدثيّ المفضي إلى الارتياح النفسيّ. ج-بواعث" إحباطية " تداعي الأمل ": الماضي له قيمة في حياةِ الإنسانِ، إذ هو

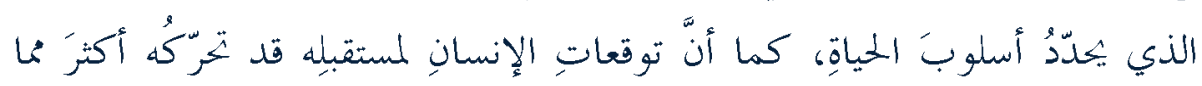

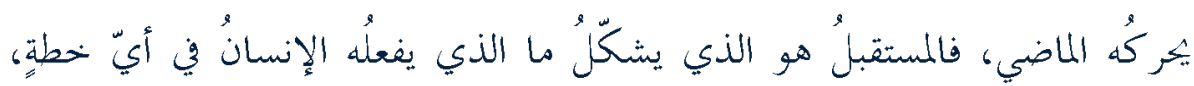

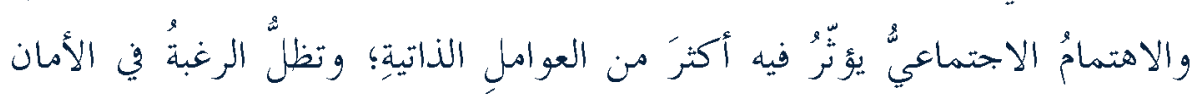

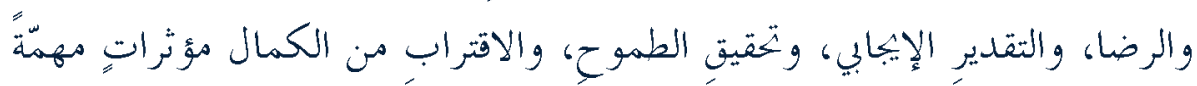

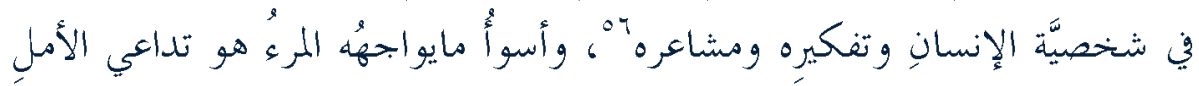

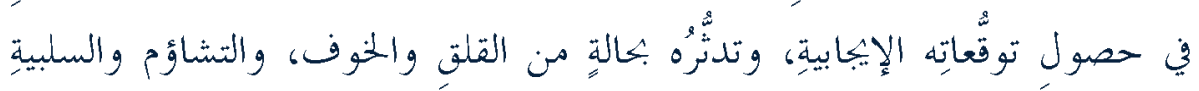
تبحاة المستقبلر

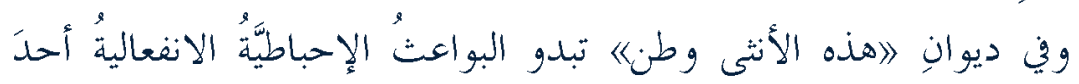

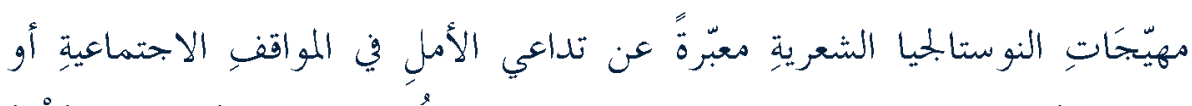

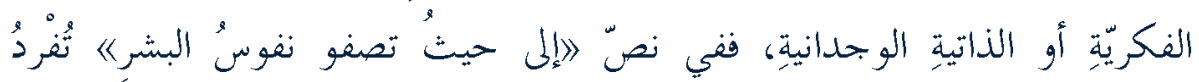

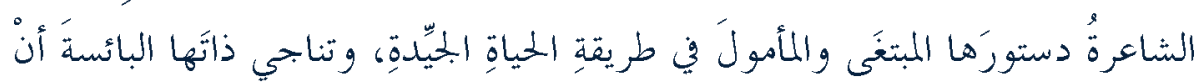

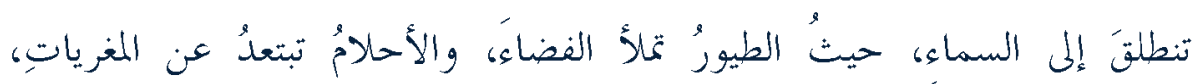

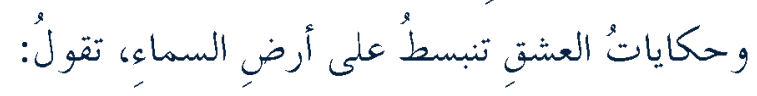




$$
\begin{aligned}
& \text { تعالي نحلّق فوقَ السماءْ } \\
& \text { نطير "إلى حيث نغزو الفضاء فون } \\
& \text { نطيرُ هناك بأحلامنا } \\
& \text { إلى حيث' تبتعدُ المغرياتُ نطاتو } \\
& \text { وتنلكَ وذاك } \\
& \text { تعالي هناك } \\
& \text { تعالي هاجرُ حيث الطيور } \\
& \text { تغردُّ قبل ابنهاب المساء } \\
& \text { وحتى المساء } \\
& \text { يهدهدُ تلك بأنغامِه }
\end{aligned}
$$

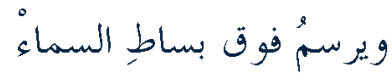

$$
\begin{aligned}
& \text { حكايات عشق تير } \\
& \text { قديك }
\end{aligned}
$$

والنصٌّ يعكس" رغبةً جامحةً في المروب هن الأرضر/ الواقع، بكل مافيهما

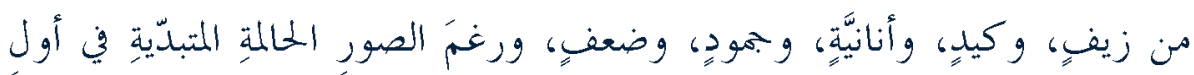

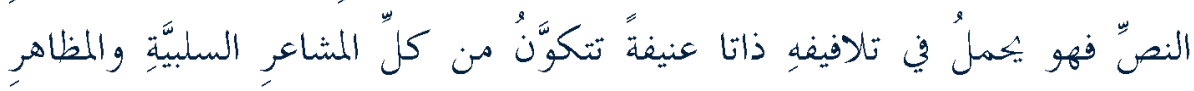

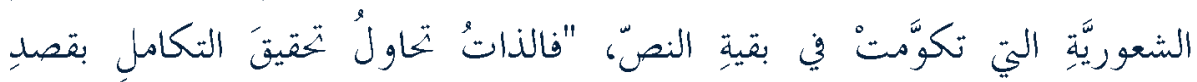

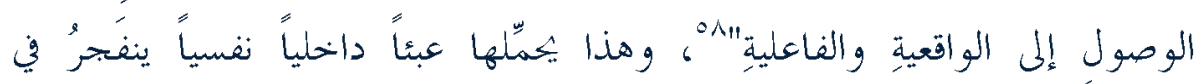

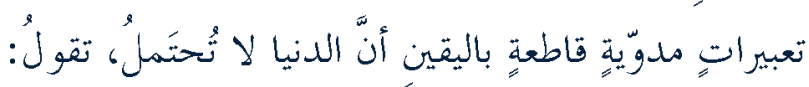

$$
\begin{aligned}
& \text { تعالي هناك } \\
& \text { إلى رفقة الحبّ و الذكريات } \\
& \text { إلى حيث تنتصرُ الأمنيات } \\
& \text { إلى حيث ثنطلقُ السنسلة }
\end{aligned}
$$




$$
\begin{aligned}
& \text { و ننأى عن الكيد والأسئلة }
\end{aligned}
$$

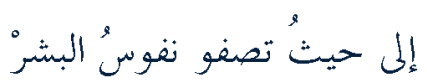

$$
\begin{aligned}
& \text { ويكلو القمر } \\
& \text { فليس الصديقُ يخون الصديقٌ } \\
& \text { وليس الرفيتٌ ينادي 》أناني } \\
& \text { فكلّ النساء هناك حسانْ }
\end{aligned}
$$

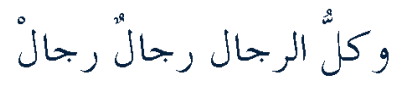

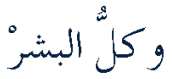

$$
\begin{aligned}
& \text { وكل الأماني } \\
& \text { وكلُّ الصوز الانم }
\end{aligned}
$$

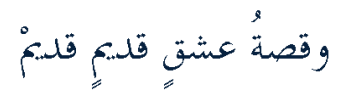

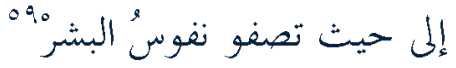

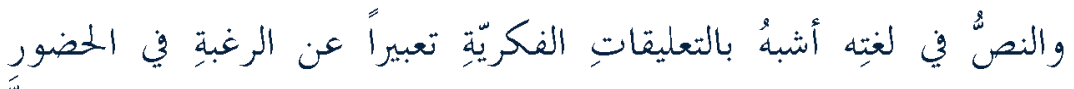

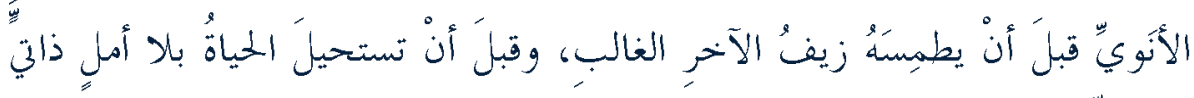

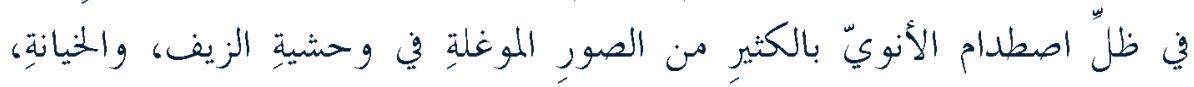

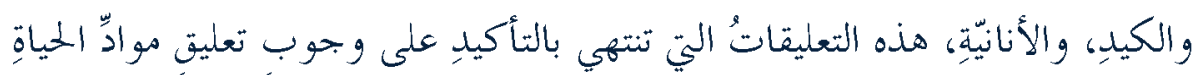

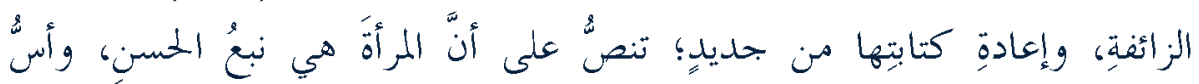

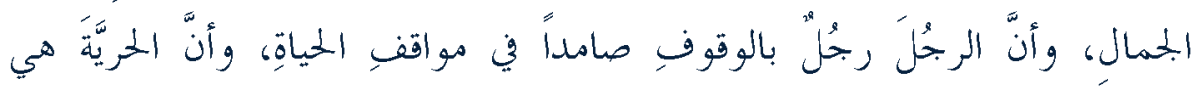

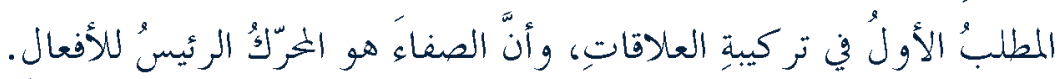

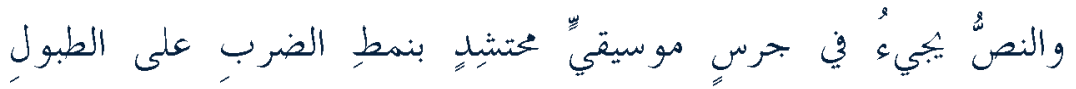

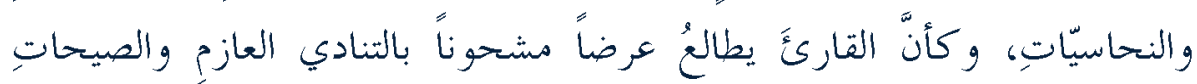

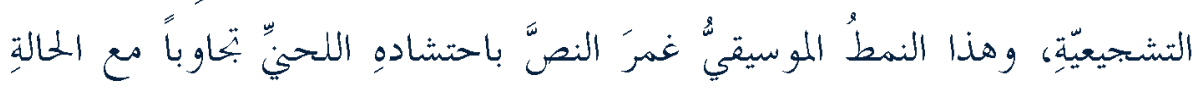


الكامنةِ في النفسِ المطالبةِ - في الوعي الأنويِّ- بضرورةِ المسارعةِ إلى التغيير، وإلى

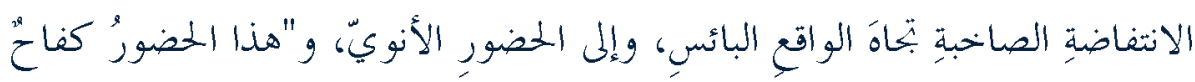

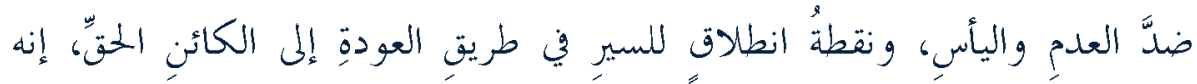

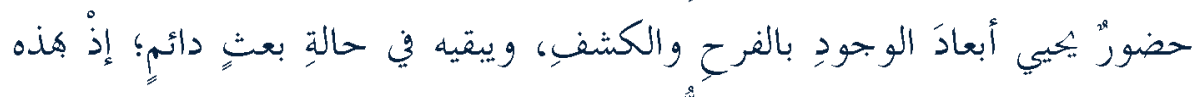

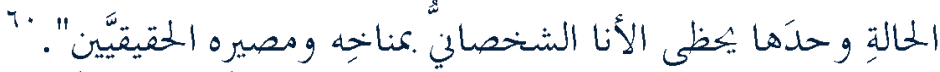

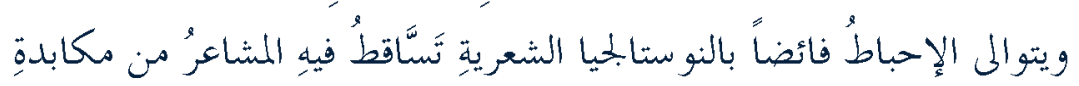

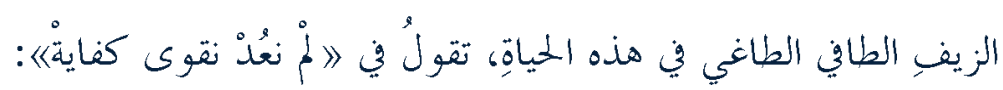

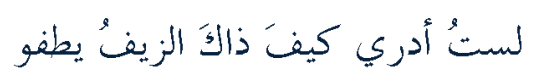

$$
\begin{aligned}
& \text { كيف يطغى } \\
& \text { ثم يرتدُ جناية } \\
& \text { يلبس" الألوانَ زهوا ئنايه } \\
& \text { ميمتطي لحَّ الكالام }
\end{aligned}
$$

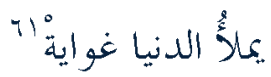

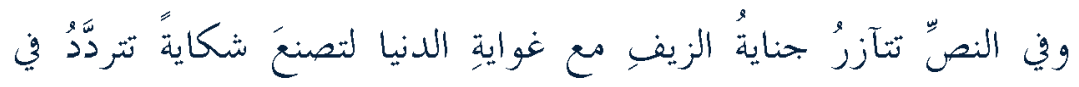

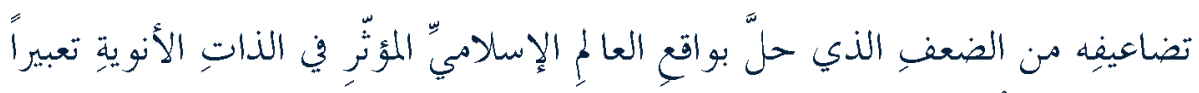

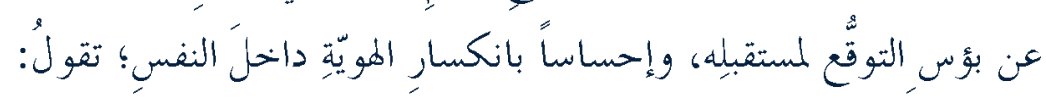

$$
\begin{aligned}
& \text { لم نُعْد نقوى كفاية } \\
& \text { كي نقول الحقَّّ جهرا } \\
& \text { كي هزّ الأرضَ نصرا }
\end{aligned}
$$

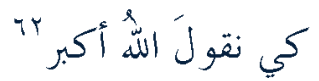

وإنَّ منتهى تداعي الأملِ في الذاتِ الأنويةِ أنْ هُجسَ النفسُ بعدمِ قدرتها

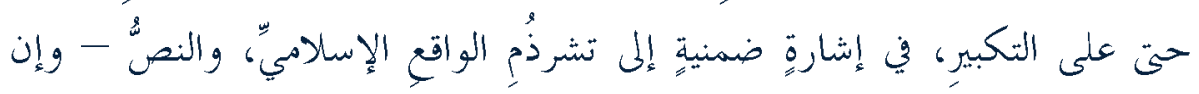

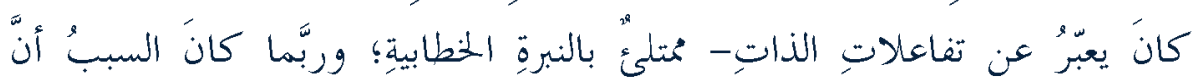




\section{النوستالجيا الشعرية بين الأنا والآخر في ديوان (هذه الأنثى وطن) لأسماء الجنويي}

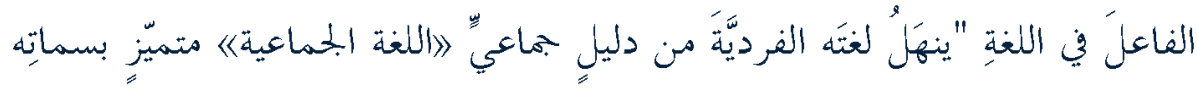

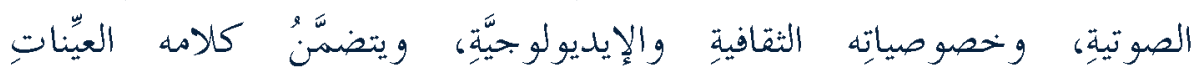

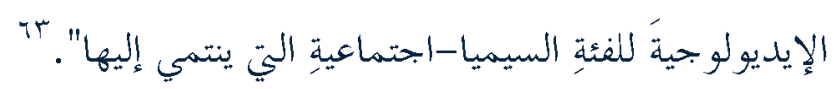

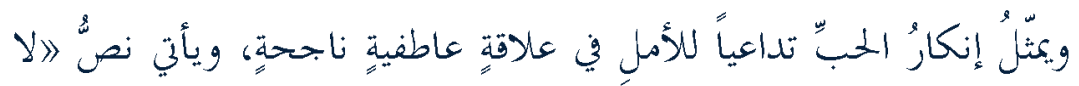

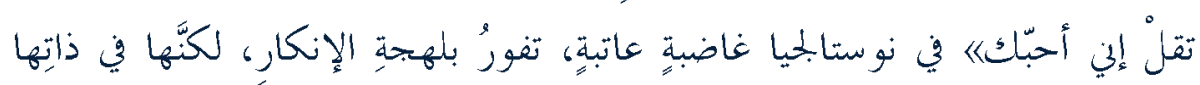

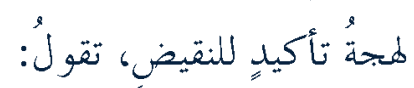

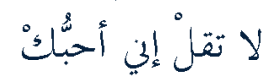

لستُ مشتاقًا إليكَ' احبك،

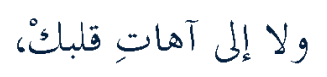

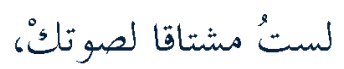

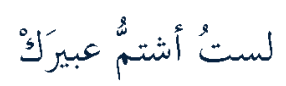

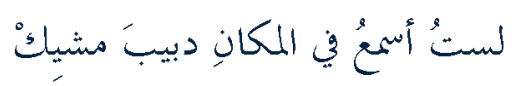

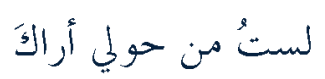

إذا رحلت

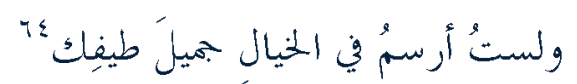

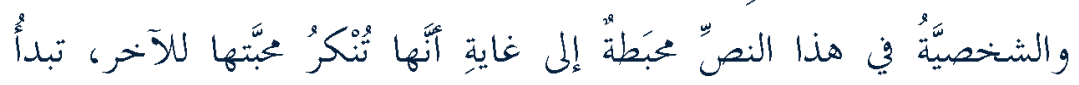

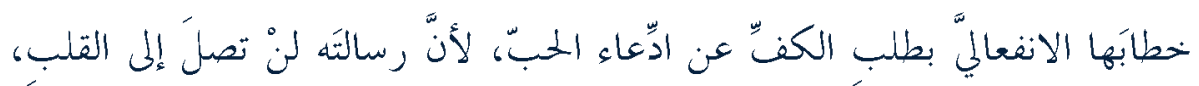

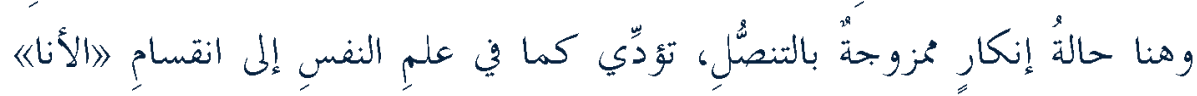

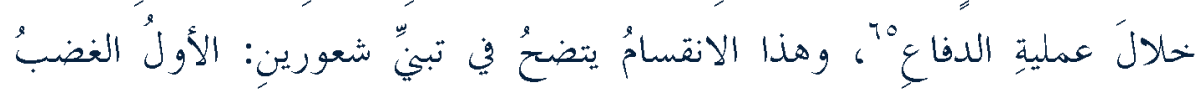

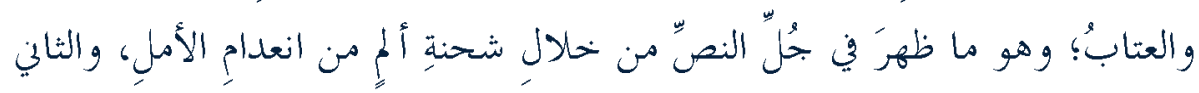

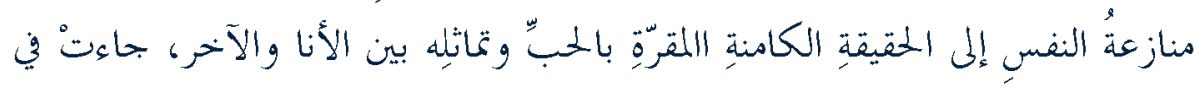
قولئا: 


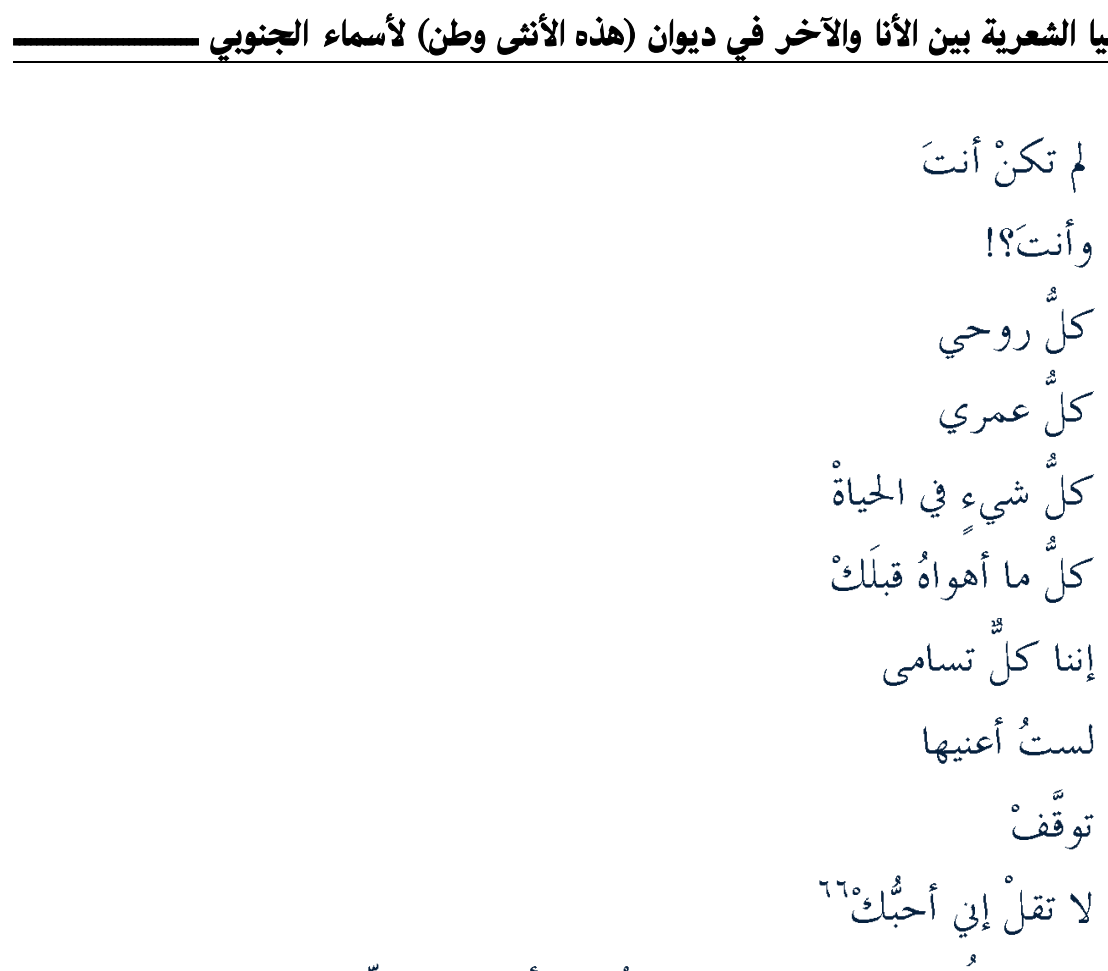

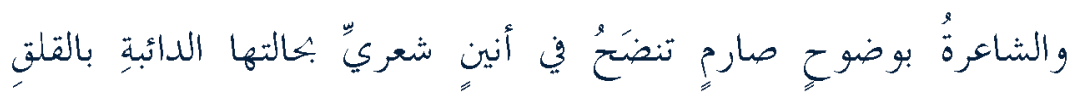

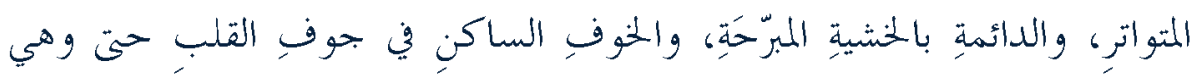

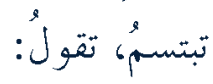
هذي أنا

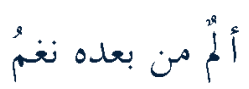

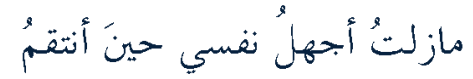

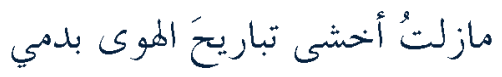
وإن كنتُ أبتسنُ يسكنين

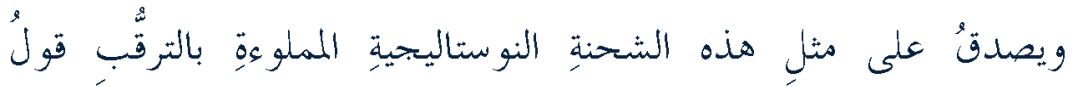

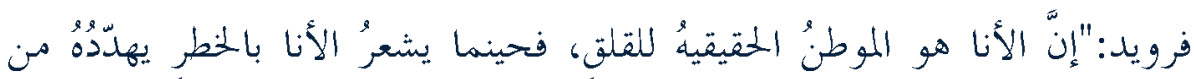

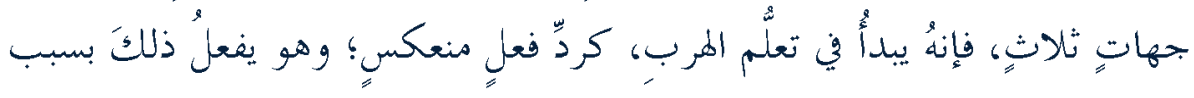

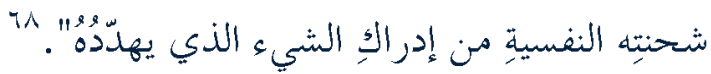




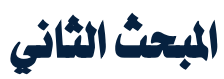 \\ تجليات الآخر في الثوستالجيا الشعريل في "هذه الأثنى وطن"}

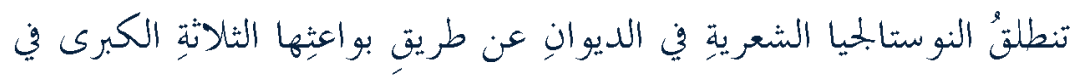

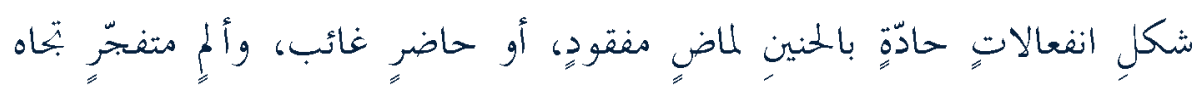

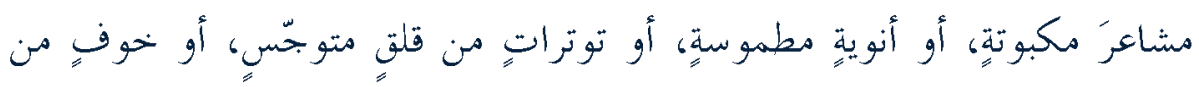

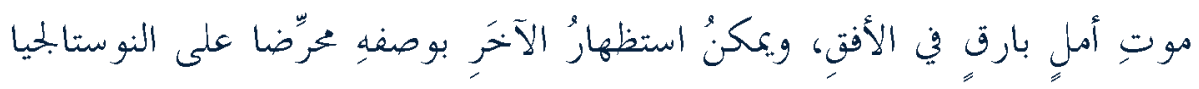
بالإيباب أو السلب، وفق الآيتي:

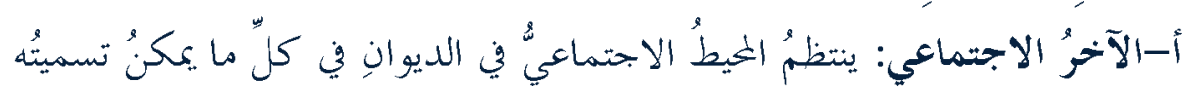

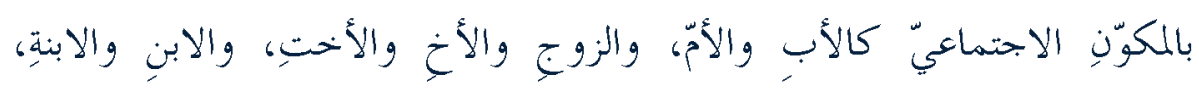

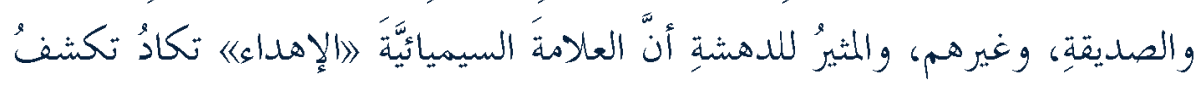

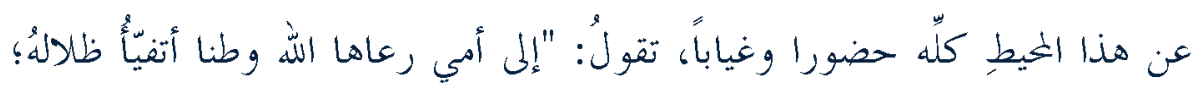

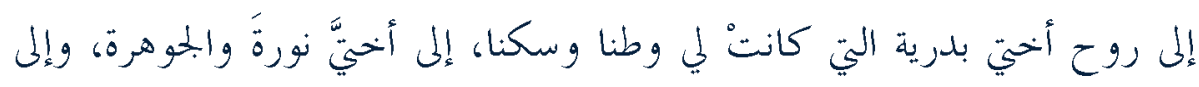

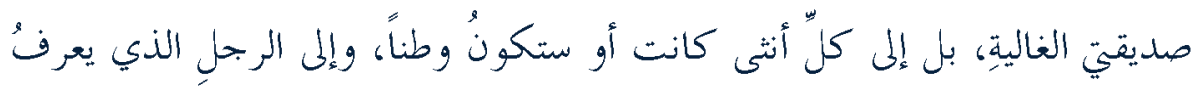

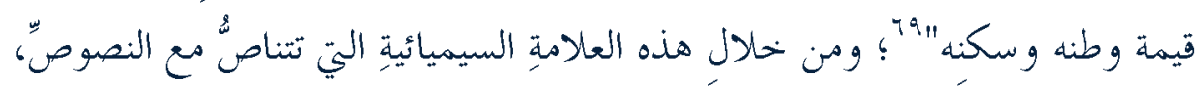

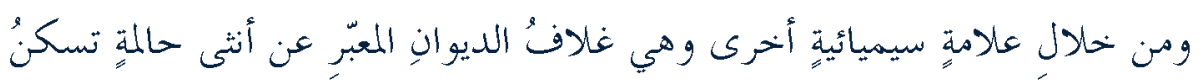

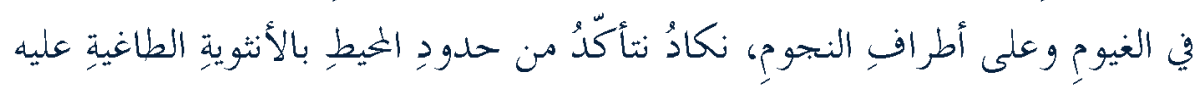
حضورا، وبالجنس الآخر غياباً.

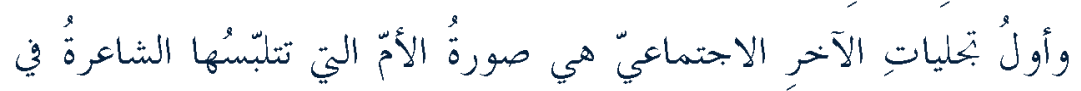

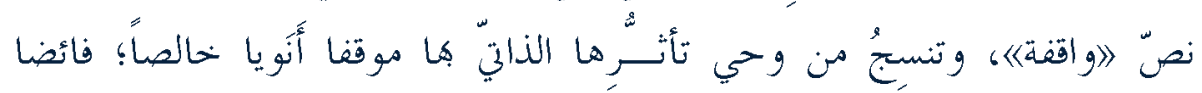

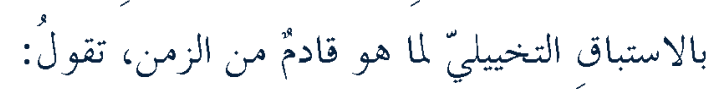
عندما أغدو عجوزا

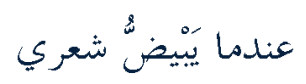
وأواريهِ بشيء من أفانين النساء 


$$
\begin{aligned}
& \text { سوفَ أبقى و اقفةْ } \\
& \text { بل سأعلو شامخة } \\
& \text { سوف أْفُشي بعضَ أسراري لبعضي }
\end{aligned}
$$

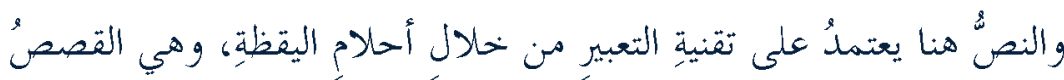

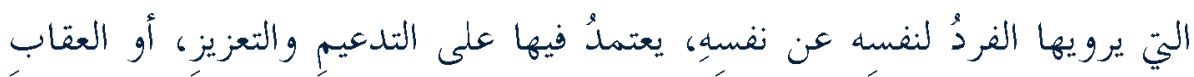

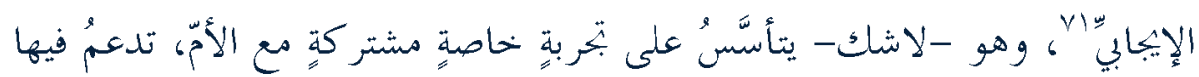

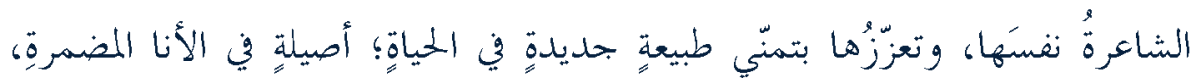

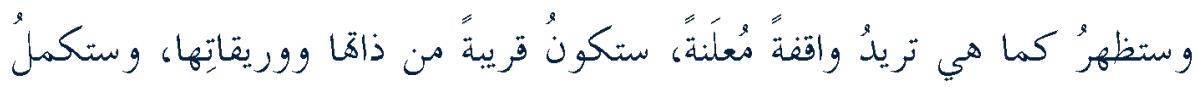

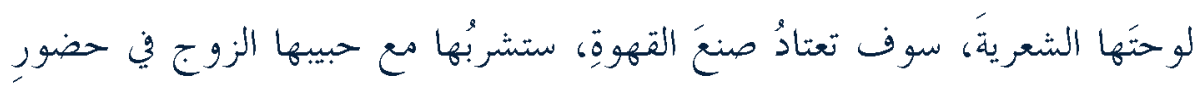

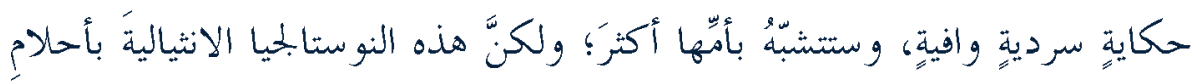

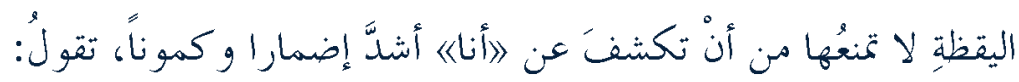

$$
\begin{aligned}
& \text { لكنين }
\end{aligned}
$$

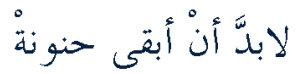

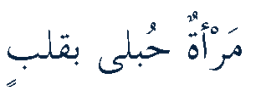

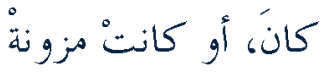

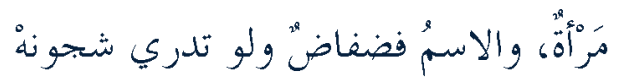

$$
\begin{aligned}
& \text { سوف تَبْقى نَ }
\end{aligned}
$$

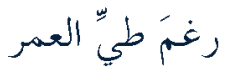

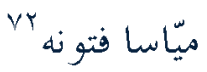

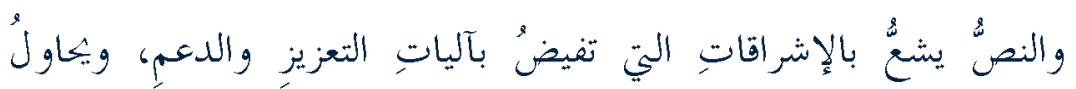

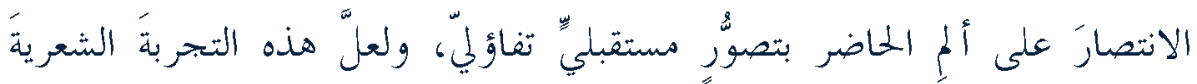

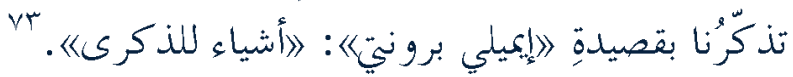




\section{النوستالجيا الشعرية بين الأنا والآخر في ديوان (هذه الأنثى وطن) لأسماء الجنوبي}

وفي الديوانِ مناجاةُ للابنة، يجتمعُ فيها الحنينُ للماضي، وخشيةُ الألمِ

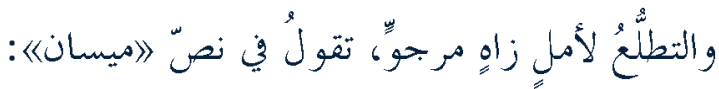

$$
\begin{aligned}
& \text { كوني حياتي، وكوني النورَفي لغتي } \\
& \text { يافرحةَ العمر، يا أحلى حكاياتي }
\end{aligned}
$$

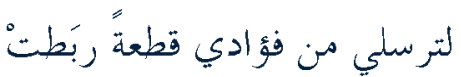

$$
\begin{aligned}
& \text { قلبَ السعادةِ بالأحالام والآتي } \\
& \text { كوبي شبابي وحسني حين أطلبُ }
\end{aligned}
$$

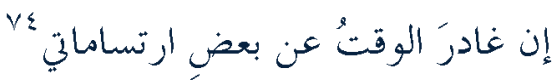

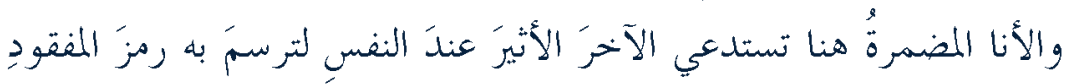

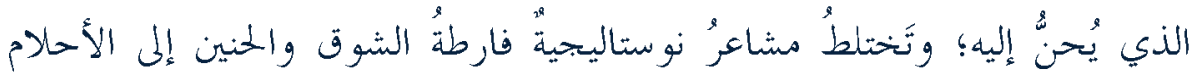

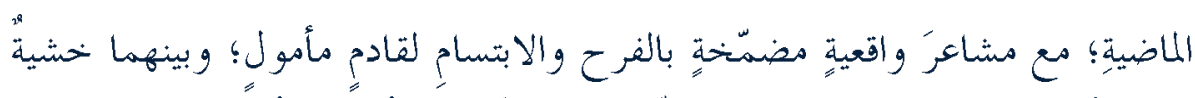

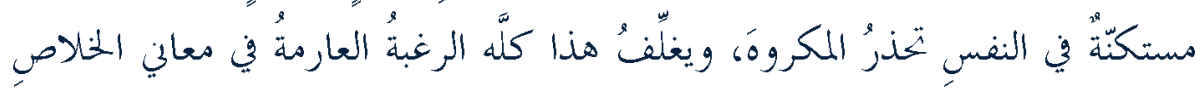

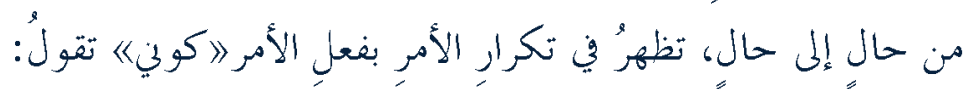

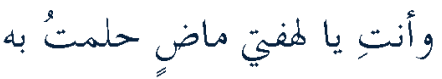

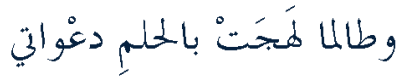
وأنت يومي إذا صبَّحتُه فرحسا وقادمٌ سوف يأتي بابتساهاتي

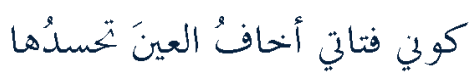

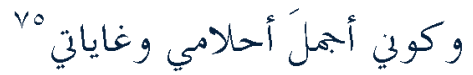

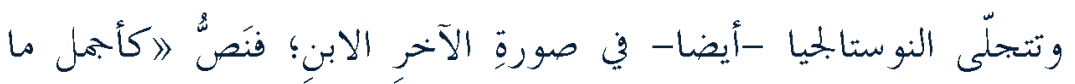

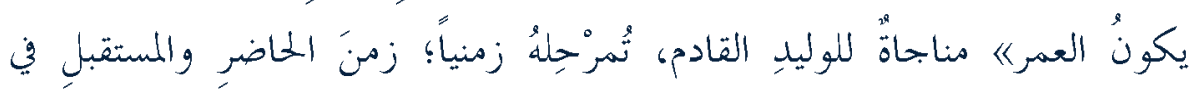




\section{النوستالجيا الشعرية بين الأنا والآخر في ديوان (هذه الأنثى وطن) لأسماء الجنوبي سـ}

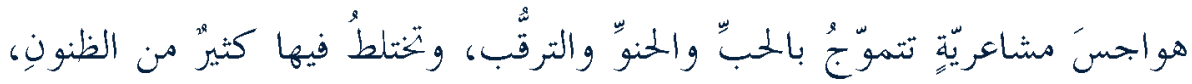

$$
\begin{aligned}
& \text { تقول: }
\end{aligned}
$$

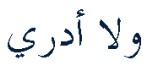

$$
\begin{aligned}
& \text { إذا ما دارت الأياجُ } \\
& \text { كيفن تكون } \\
& \text { وكيفن أكونج" } \\
& \text { وكيفن نكون" إحساسا } \\
& \text { إذا ما مرَّت الدنيا } \\
& \text { وقالت في ترقرقها: } \\
& \text { حكايتّه } \\
& \text { وفعتَتُ } \\
& \text { وتركتَ } \\
& \text { ويوماً كان مولنه }
\end{aligned}
$$

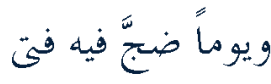

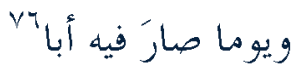

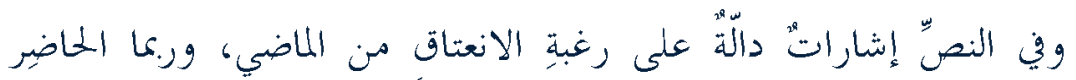

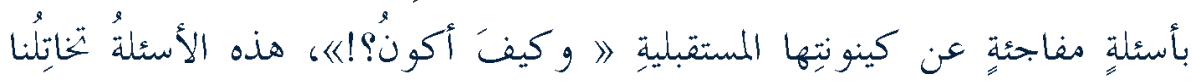
بشعورِ القلقِ من تداعي أملٍ ما، بعد أن منحتَنا بألفاظٍٍ رشيقةٍ شعورَ الفرحةٍ

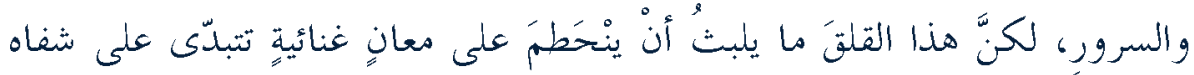

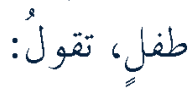
أحسبّاك لا تقل أمي وقلها كيفما نطقت شفاهُك حالَّا بالأمسن 


$$
\begin{aligned}
& \text { فقل 》امامانا، وقل 》أمّانا } \\
& \text { لأنك أنت يا ولدي } \\
& \text { صغيري } \\
& \text { حاز سحرَ الكون } \\
& \text { وقبي حين أبصره } \\
& \text { فأبصر جنّة الدنيا }
\end{aligned}
$$

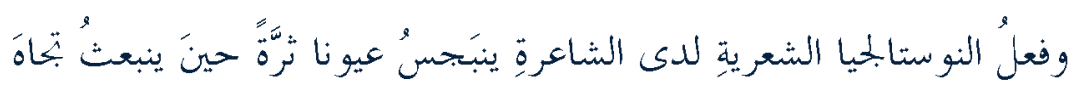

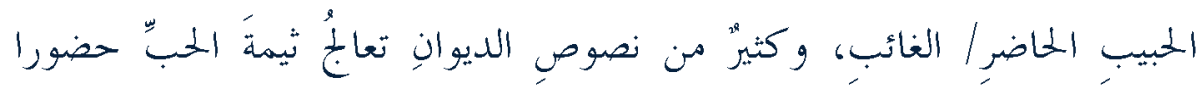

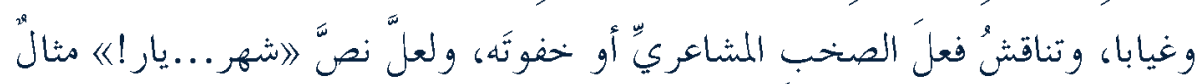

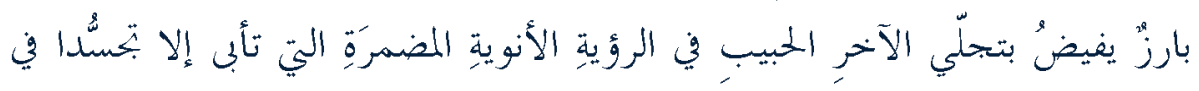

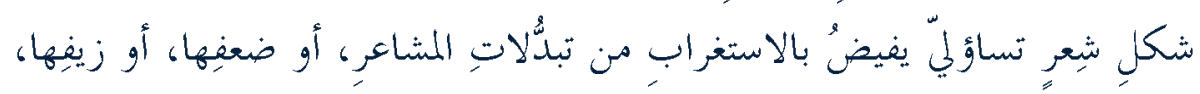

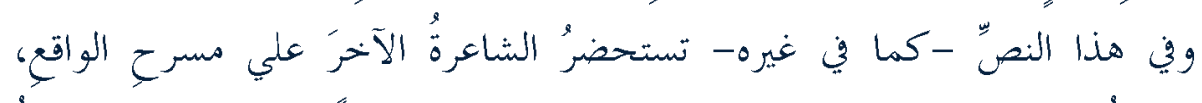

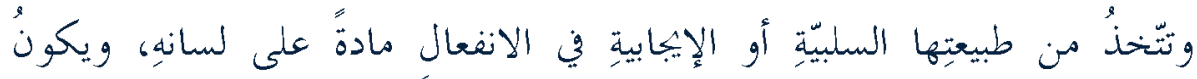

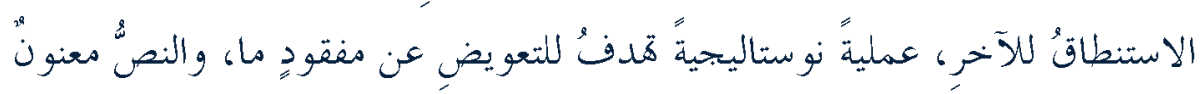

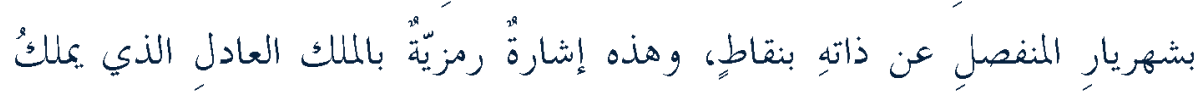

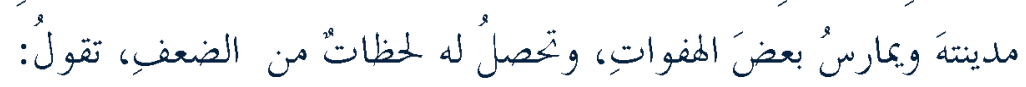

$$
\begin{aligned}
& \text { لا لن تكوبي هكذا } \\
& \text { قلبا حنونا دافئا؛ } \\
& \text { فالحبتُ يأسرُّي } \\
& \text { فأبقى } \\
& \text { مغََّضَ العينين } \\
& \text { دهرا واقفالمي لدين }
\end{aligned}
$$




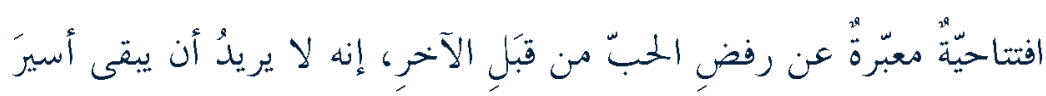

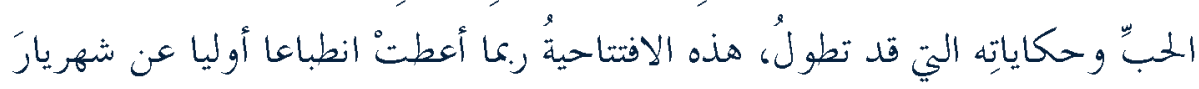

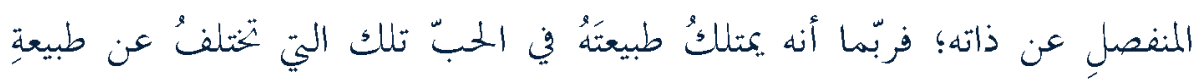

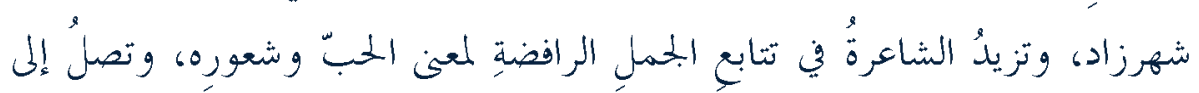
مشهدِ الرفضِ الكبيرِ الواضح، تقول:

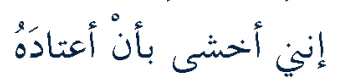

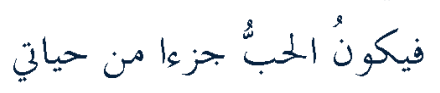

لستُ أغفو دوزنهُ

حينما يأتي المساء

والنصٌّ يأتي واحدةً من آلياتِ الدفاع وإثباتِ الذاتِ عن طريثِ ترميمر.

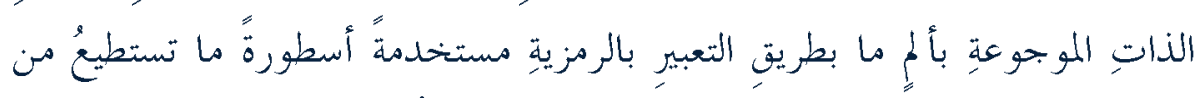

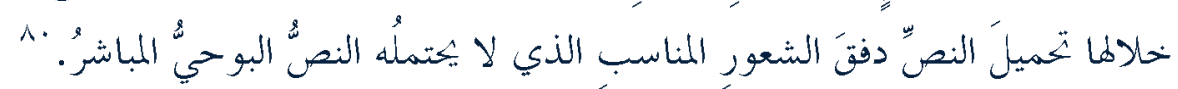

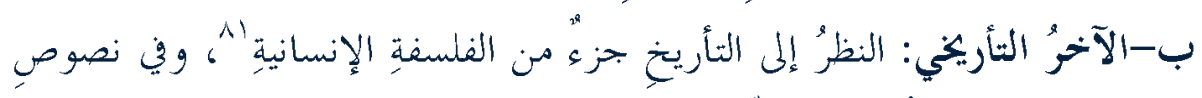

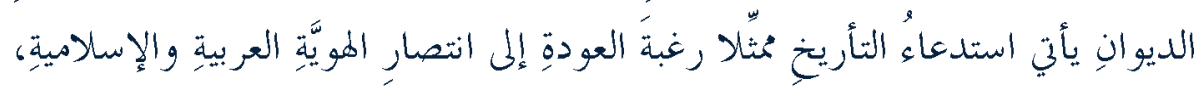

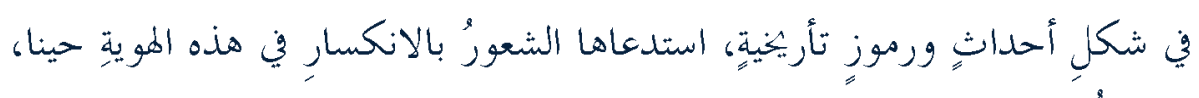

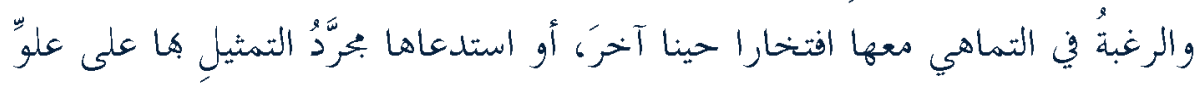

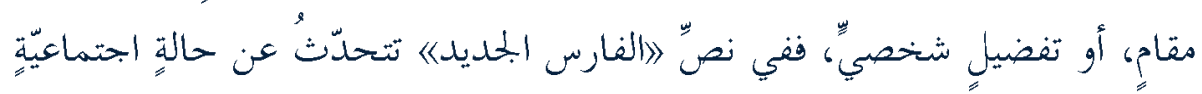

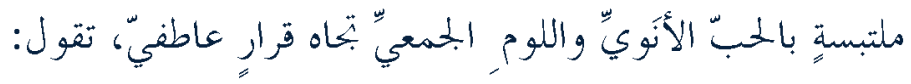

$$
\begin{aligned}
& \text { لم يكنْ ذاك الأميرَ الفارسَ المقدامْ } \\
& \text { مثلَ أبي فراسْ }
\end{aligned}
$$

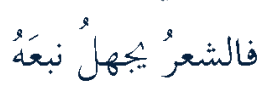

$$
\begin{aligned}
& \text { بل كان مزجيَّ المراسن بعهد }
\end{aligned}
$$




$$
\begin{aligned}
& \text { كانت تراهُ بعينها } \\
& \text { أقوى وأشعر } \\
& \text { كان الحليمَ الطيّبَ الأواهْ } \\
& \text { يلبس' "ثوبَ عنترْ } \\
& \text { أوْ كانَ في ذاتِ الفؤادِ } \\
& \text { فكان أظهر مُ ن } \\
& \text { بل كان شيئا جاوزَ التأريخَ }
\end{aligned}
$$

$$
\text { واخترق البطل }
$$

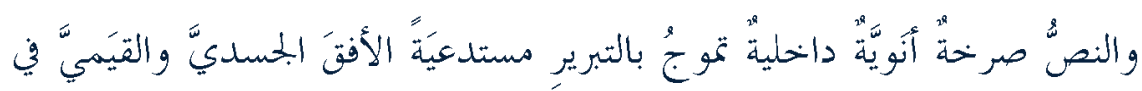

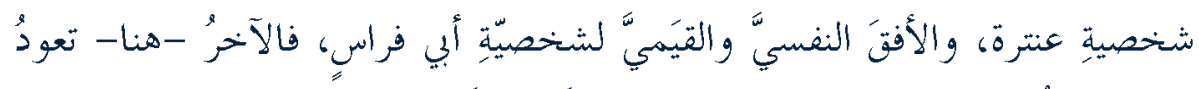

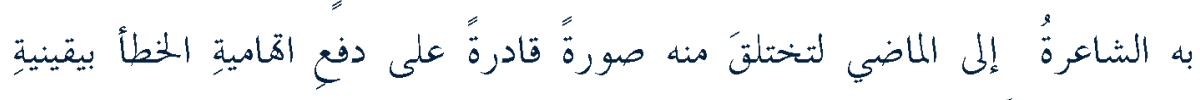
الصوابِ، لأنَّ القرارَ كانَ أنويَّ الطابع رغم كثرةِ اللائمين؛ تقول

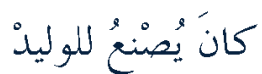

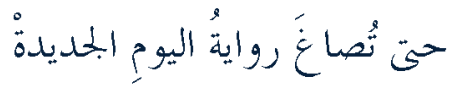

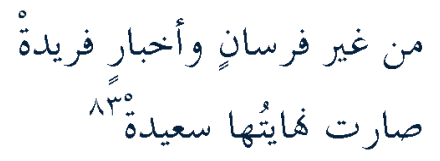

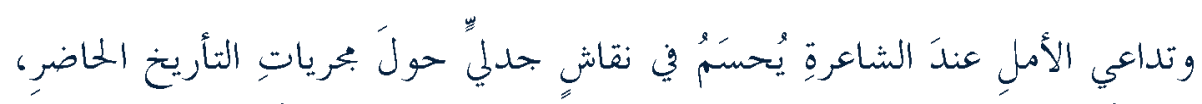

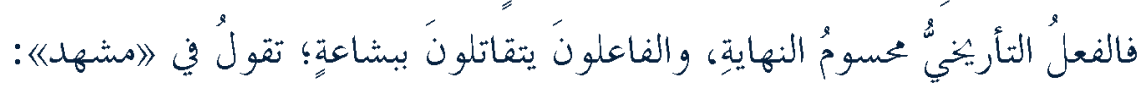

$$
\text { كتدَ التأريخُ هو يَّتَهُ }
$$




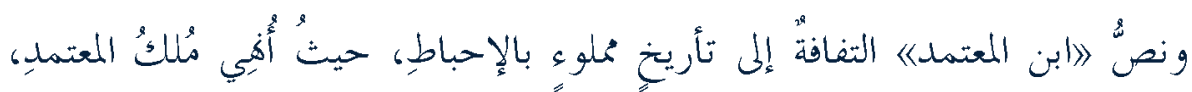

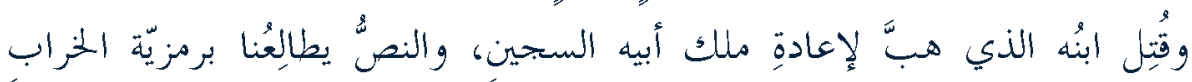

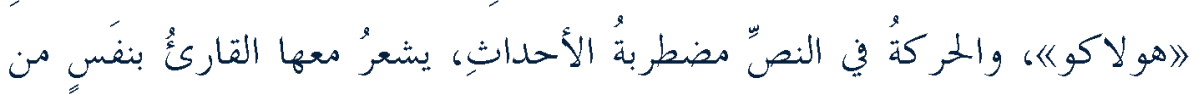

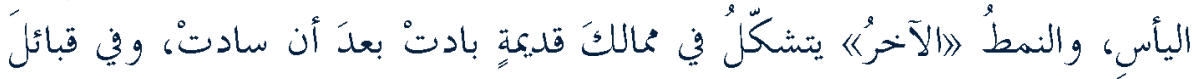

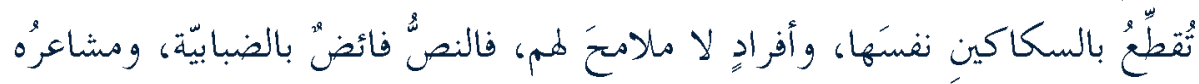

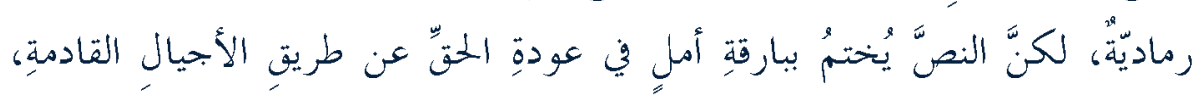
تقول: رمان: قلت

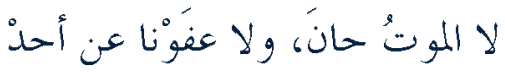

$$
\begin{aligned}
& \text { وتوقَّفَ الوقتُ الجميل، و آذنتن }
\end{aligned}
$$

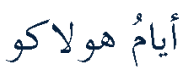

$$
\begin{aligned}
& \text { وقام المعتمدن } \\
& \text { من بعد يوم الطين } \\
& \text { إنَّ الحياةً إذا أردتَ } \\
& \text { كريمة } \\
& \text { إن كنتَ ترجو اللّ } \\
& \text { تنشدُ عفوه }
\end{aligned}
$$

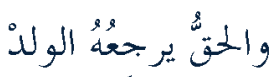

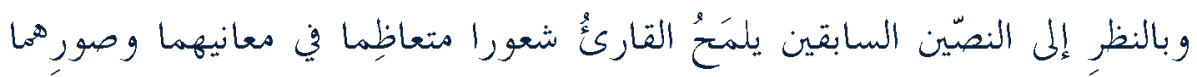

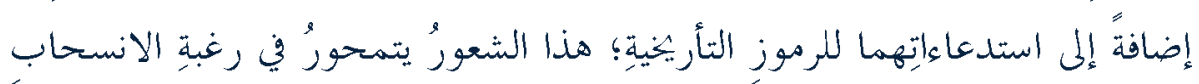

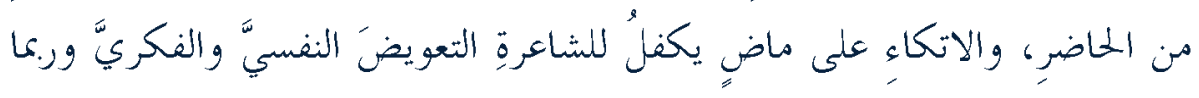
الاجتماعيَّ. 


\section{النوستالجيا الشعرية بين الأنا والآخر في ديوان (هذه الأنثى وطن) لأسماء الجنويي}

ج- الآخرُ الثقافي: تضطلعُ الثقافةُ في أهمِّ جوانبها بترقيةٍ العقل والأخلاقِ، وتنميةِ

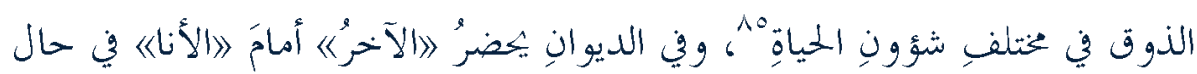

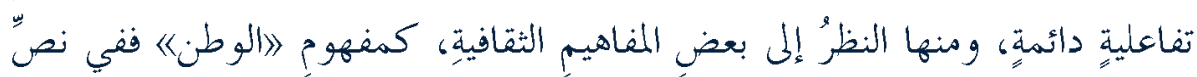

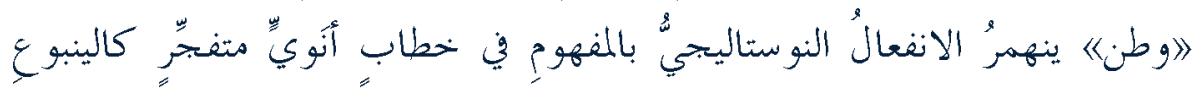

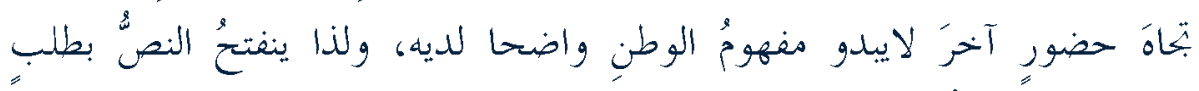

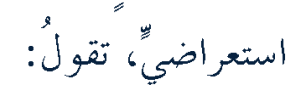

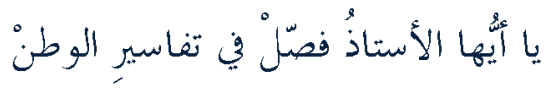

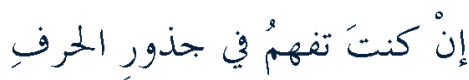

$$
\begin{aligned}
& \text { في المعنى الأصيل! }
\end{aligned}
$$

وطن: بلن

أصل وطن

Aigig

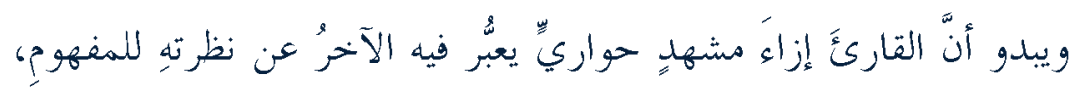

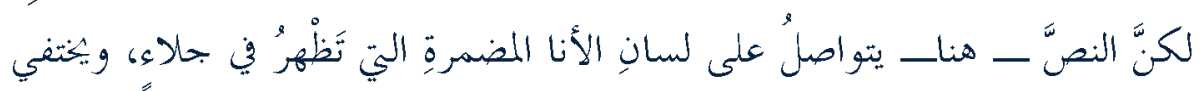

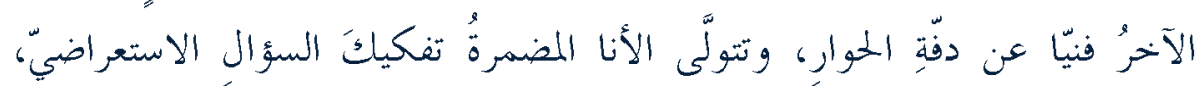

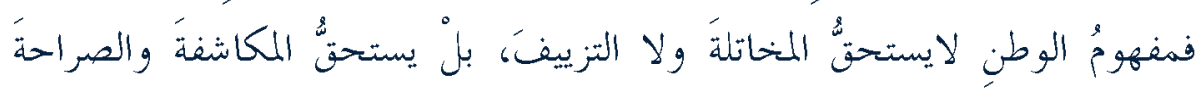

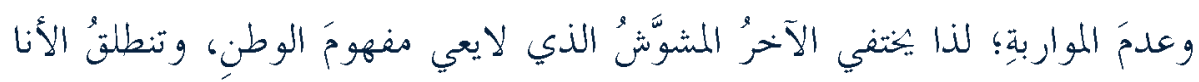

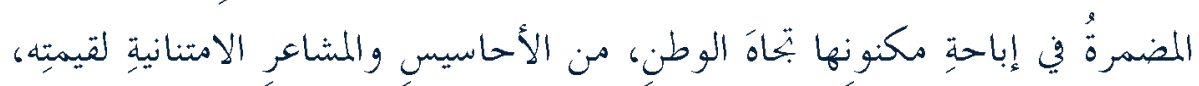

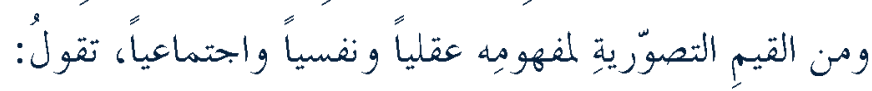

وتأخخُ هذه الأيّامُ في تقاليب الزمن

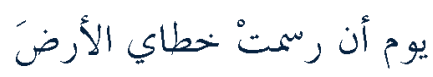




$$
\begin{aligned}
& \text { يوم وطأتها } \\
& \text { وعرفتن أني قل ورتفتُ، } \\
& \text { وقَذَّمَتْن أرَرضي الثمنْ } \\
& \text { وهن } \\
& \text { حيث أبي وأمي } \\
& \text { حيث بيتي } \\
& \text { ذلك الحضنُ الذي أودعتهُ بردَ الشتاء } \\
& \text { خونَ قني } \\
& \text { تصني } \\
& \text { وبدايتي للنماء }
\end{aligned}
$$

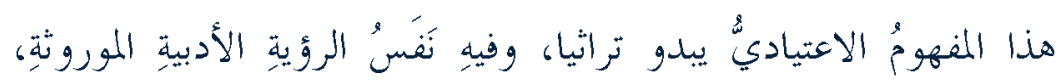

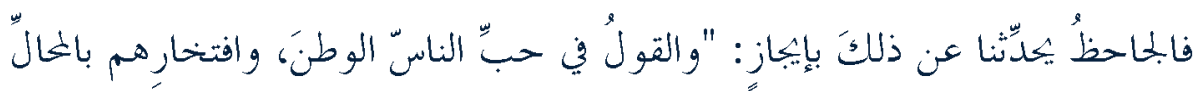

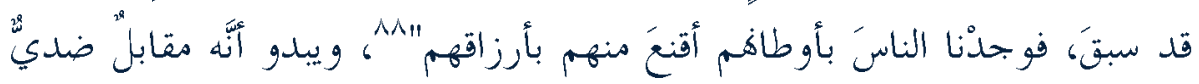

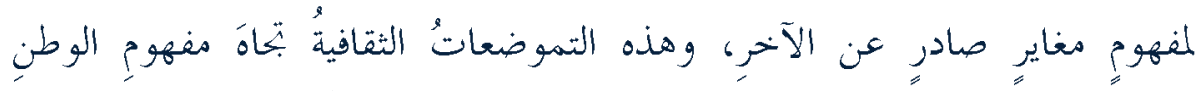

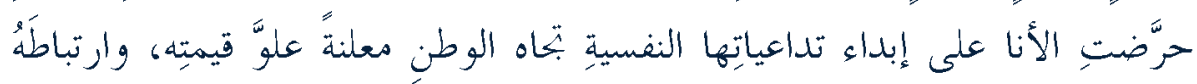

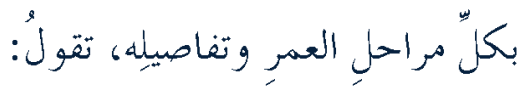

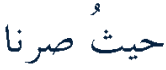

$$
\begin{aligned}
& \text { وتربئنا } \\
& \text { و وكنّا }
\end{aligned}
$$$$
\text { حيث نحن الآن }
$$$$
\text { والون: }
$$

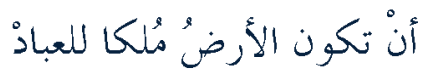




$$
\begin{aligned}
& \text { والدين' فيها خيرُ زاذ } \\
& \text { و والناس" هم أهل 'المكان }
\end{aligned}
$$

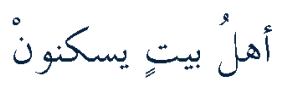

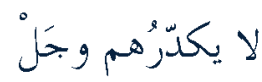

$$
\begin{aligned}
& \text { إنَّ ذاك هو الوطنْ } \\
& \text { أنْ تكونَ الابنُ في بيتِ أبيكُ إنْ } \\
& \text { واثتا } \\
& \text { تختارُ ما يجري عليكن } \\
& \text { والناسُ حولكُ يشعرونْ } \\
& \text { أهم أهل "الماكانِ }
\end{aligned}
$$

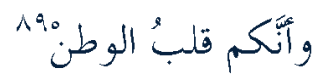

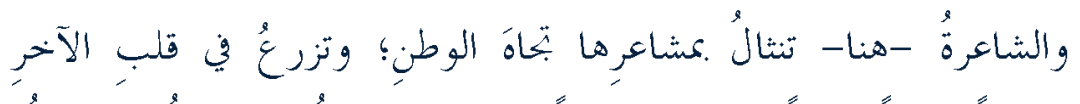

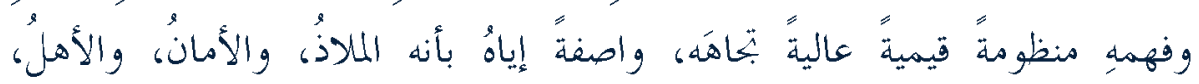

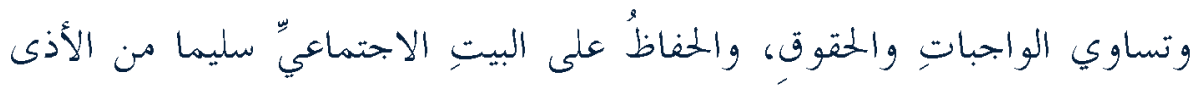
والآفةِ؛ بالخافظةِ على الدينِ وبصدق الانتماء للوطنِ.

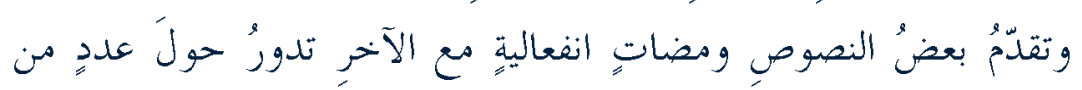

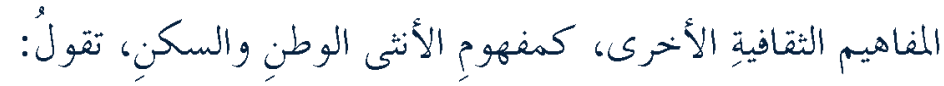

$$
\begin{aligned}
& \text { هذه الأنثى وطن: } \\
& \text { هل يعيشُ المرءُ من غير وطنْ }
\end{aligned}
$$

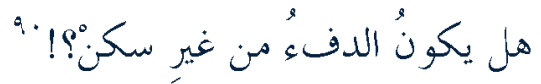

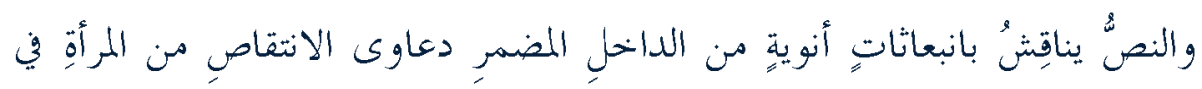

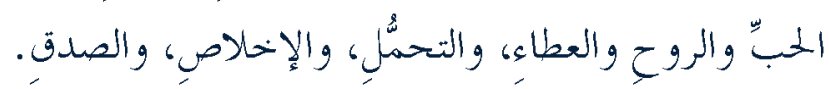




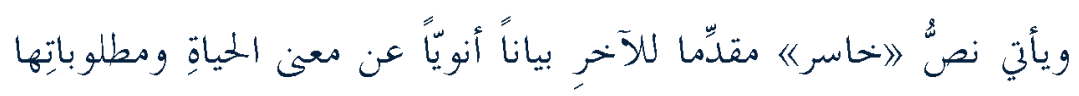

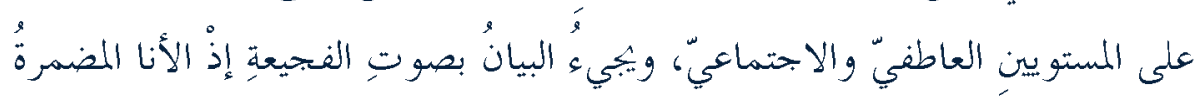

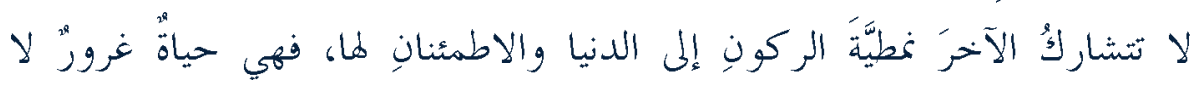

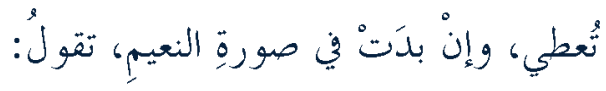
هات القلم

واكتبْ قصيدةَ ثائرِ

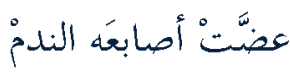
هات القنم واكتبْ كايةً عاشقِ

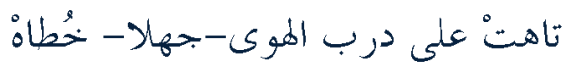

$$
\text { وذي هاياتُ الحياةْ تحلمُ بالنعيم }
$$

$$
\begin{aligned}
& \text { و الناس" من حول الفراغ دوائر" } \\
& \text { قسمُ يفوزُ بصيدهِ }
\end{aligned}
$$

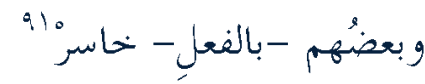




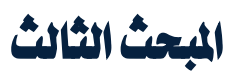

\section{الفضاء الوظيفيخ للنوستالجيا الشعرية في "هذه الأثثى وطن"}

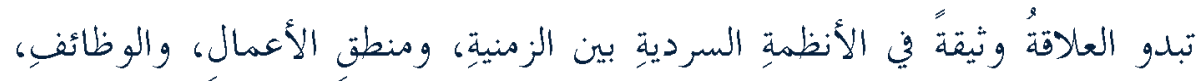

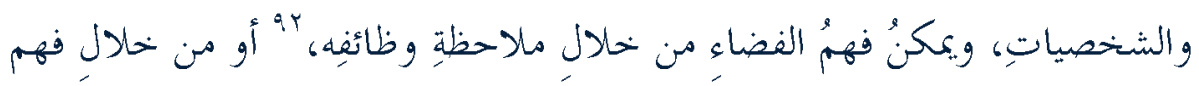

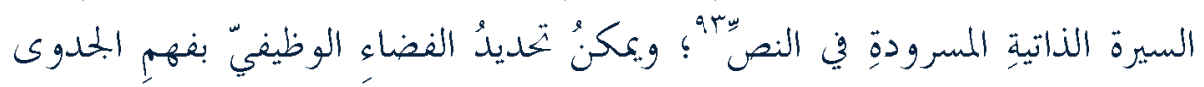

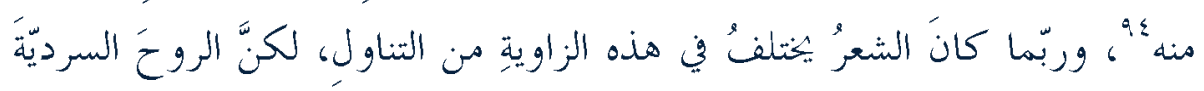

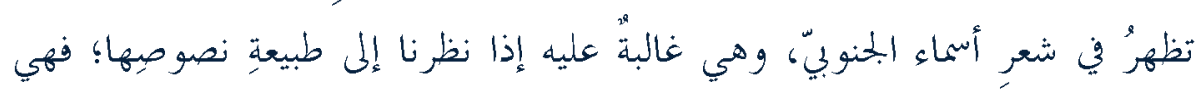

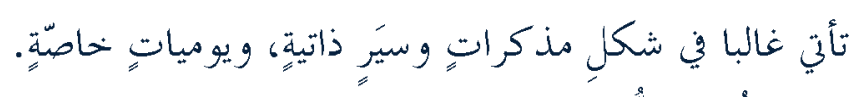

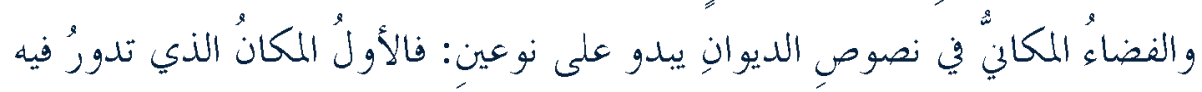

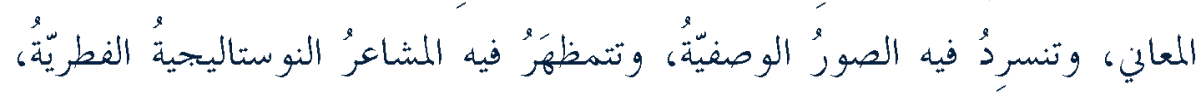

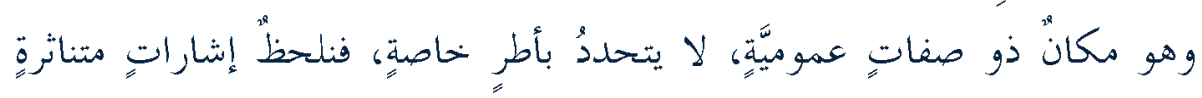

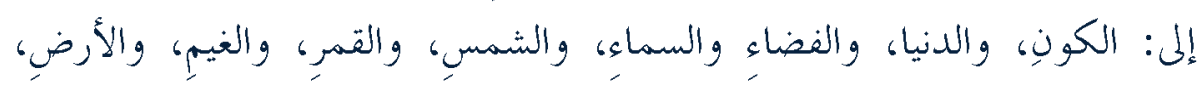

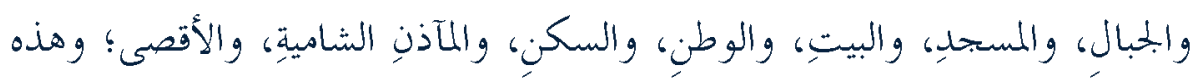

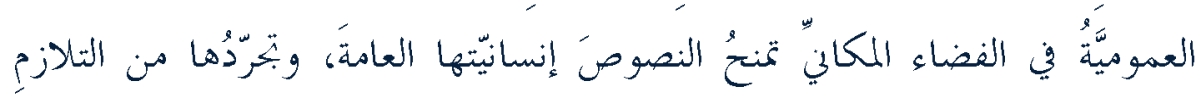

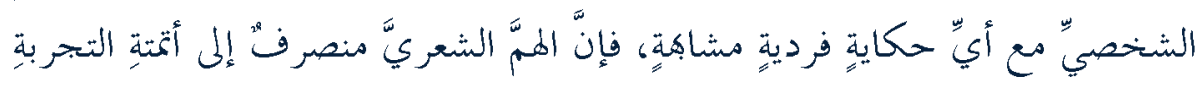

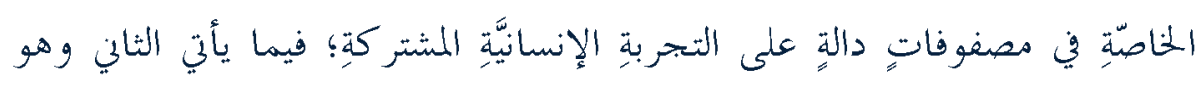

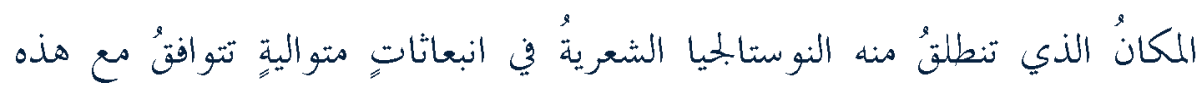
النصوصِ ذاتِ النسقِ السير-ذاتي، وهو مكانُ الأنا الخافيةِ المضمرةِ، التي تبدو مكاناً

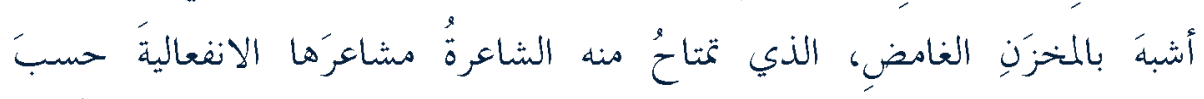

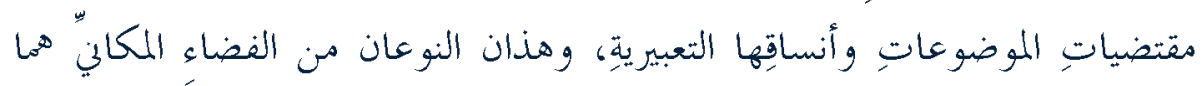

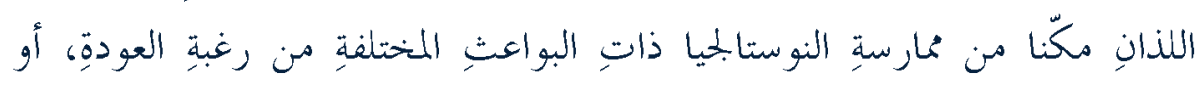
الإحساسِ بألم الفقد، أو الخشيةِ من تداعي الأملِ. 


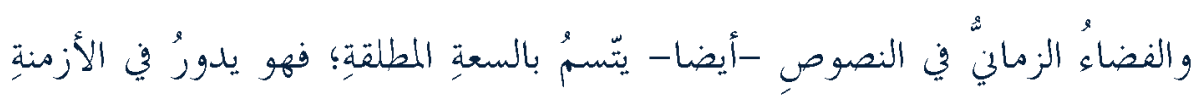

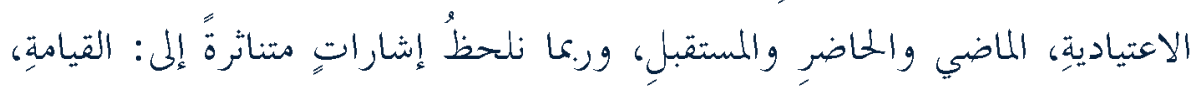

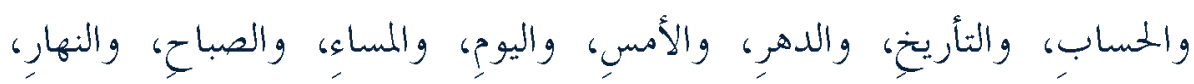

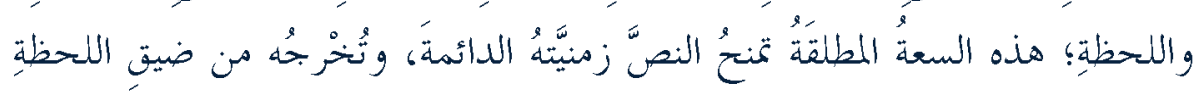

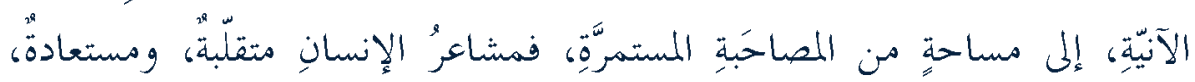
.

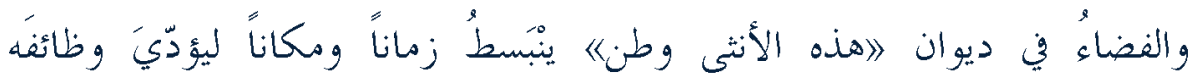

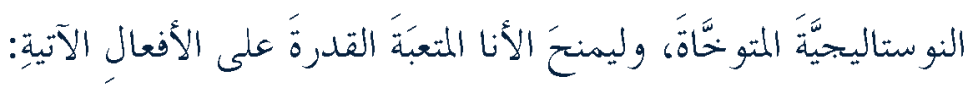

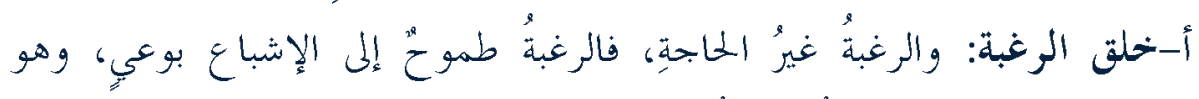

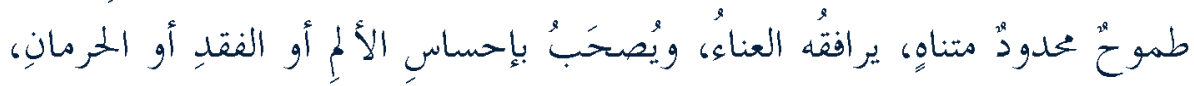

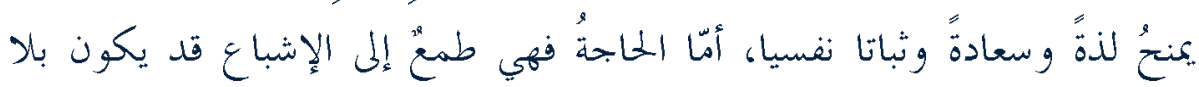

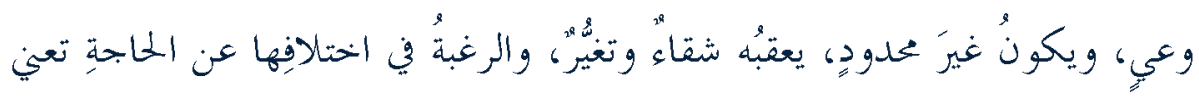

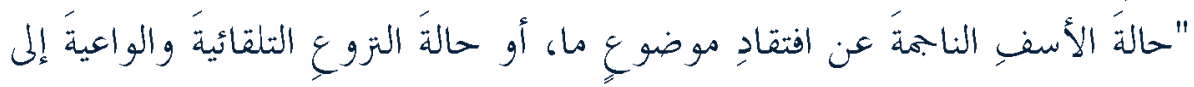

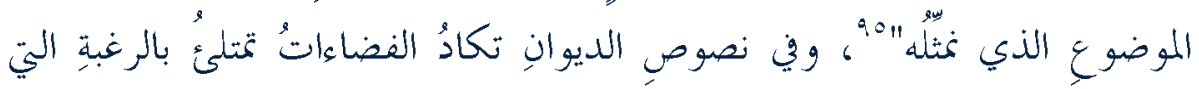

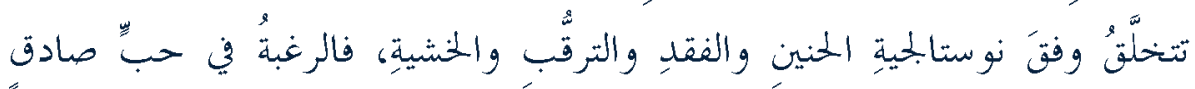

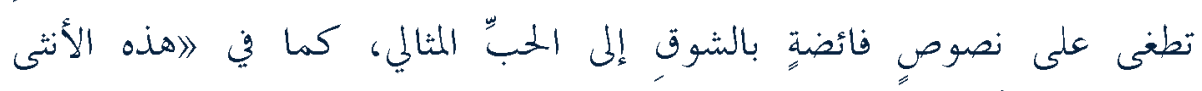

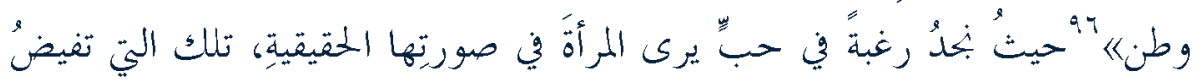

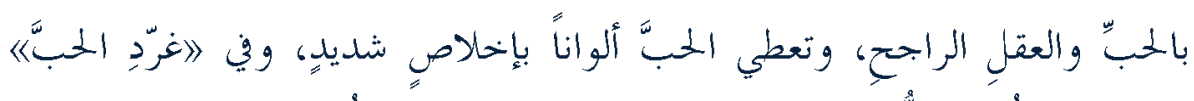

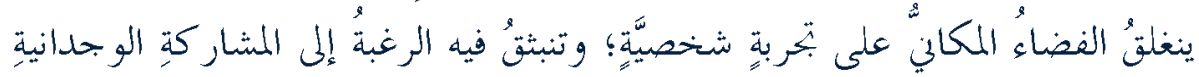

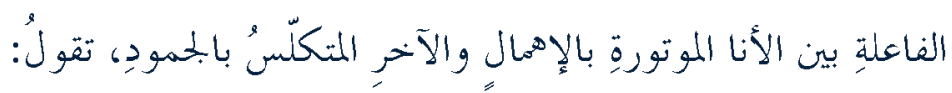
وأذا ترحمّتتُ عن أهل وعن وطنٍ 


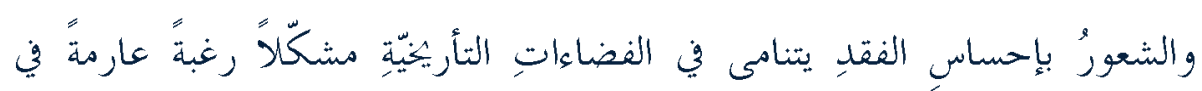

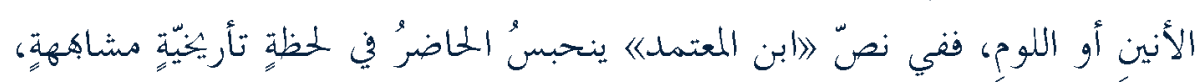

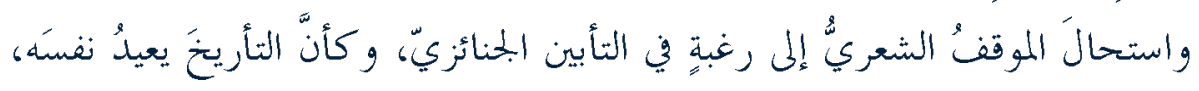
تقول:

$$
\begin{aligned}
& \text { لكنَّ من سُنّت له حدُّ الـــمْديّ }
\end{aligned}
$$

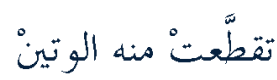

$$
\begin{aligned}
& \text { وقد استحال إلى الأبد لئ }
\end{aligned}
$$

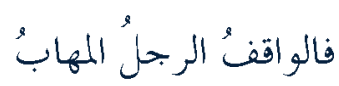

$$
\begin{aligned}
& \text { توقَّتْْ أيامُهُ } \\
& \text { وغدا يقاتله الجمسذ أنهُ }
\end{aligned}
$$

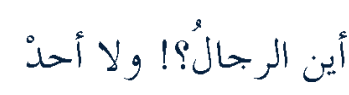

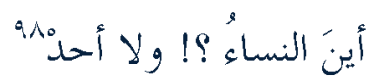

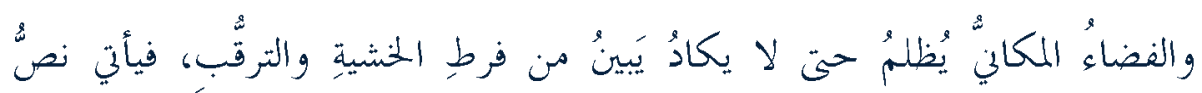

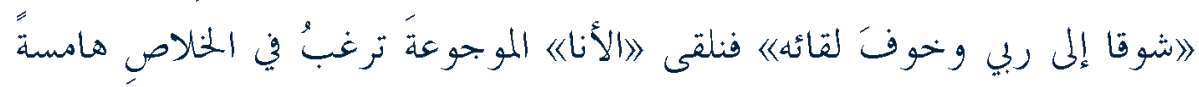

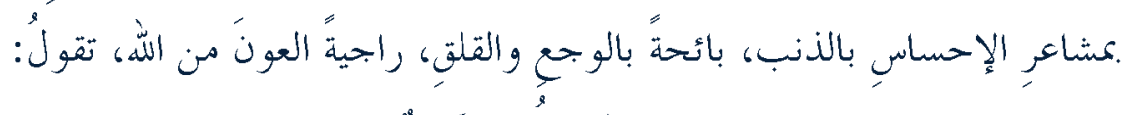

$$
\begin{aligned}
& \text { روحي وعمري والعيون سواكبُ }
\end{aligned}
$$

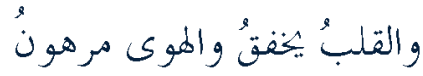

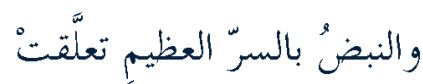

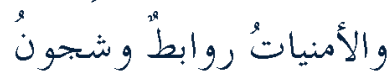

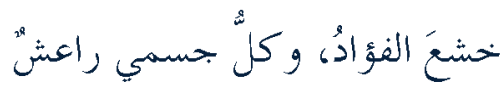

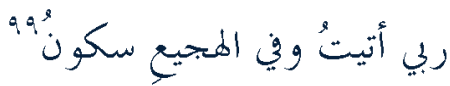


ب-جذب الانتباه والاهتمام: جذبُ الاهتمام والانتباه أمرٌ إنسانيّ اعتياديٌٌ، لكنه

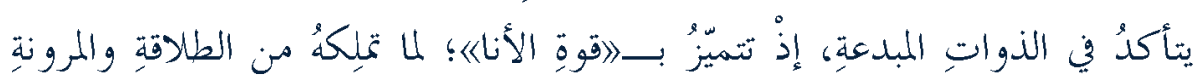

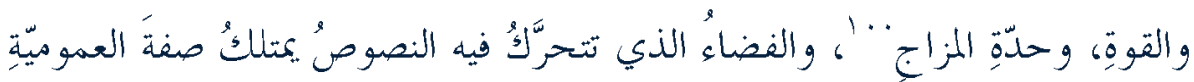

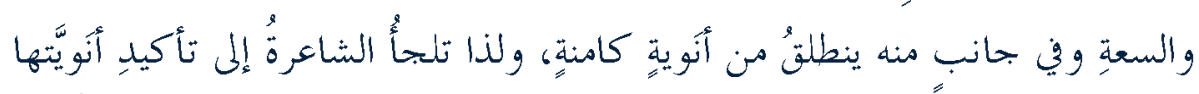

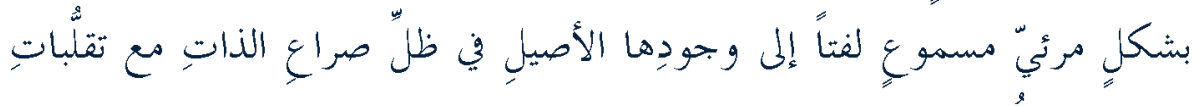
الآخر، تقول: ترنج

هذي تضاريس" ألواني

$$
\text { ورديّة ورية }
$$

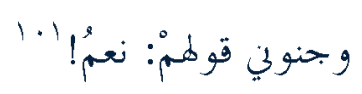

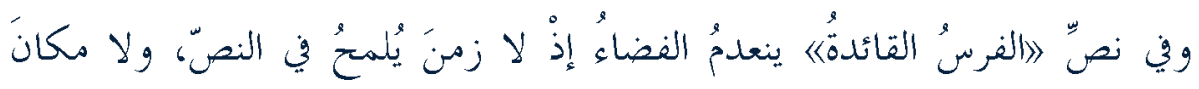

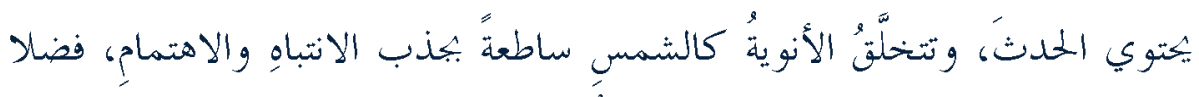

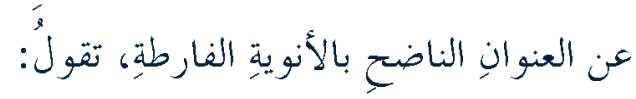

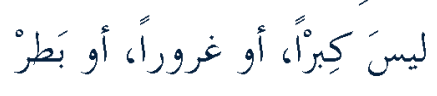

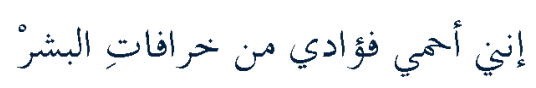

إنين لذتُ إلى نفسي بنفسي

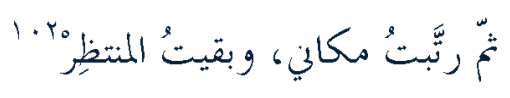

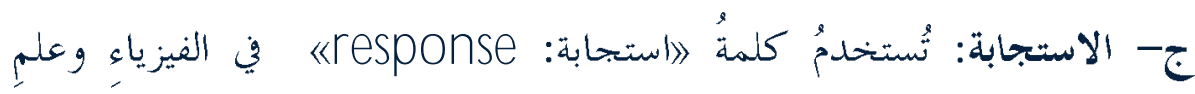

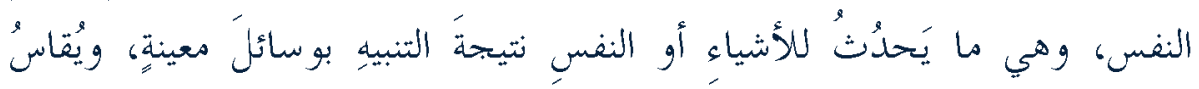

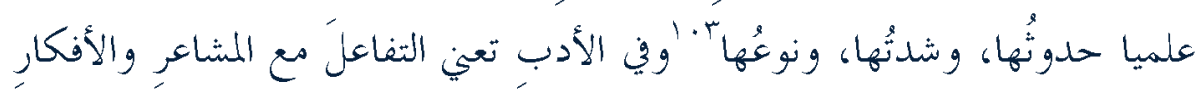

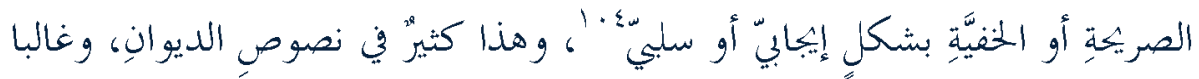

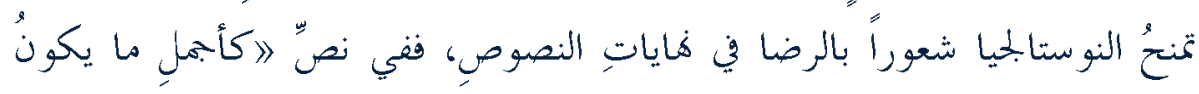




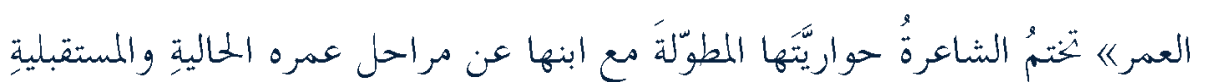

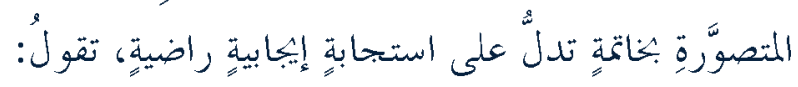
وقبي حين أبصرٌَ

فأبصرَ جنة الدنيا

فأحمدُ ربيَّ المنَّانْ

$$
\text { أنّيَ أَمْ }
$$

$$
\begin{aligned}
& \text { لطفلٍ حازَ سحرَ الكونْ }
\end{aligned}
$$

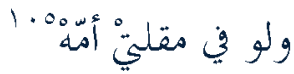

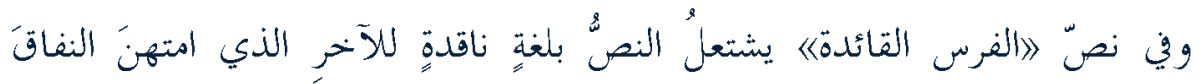

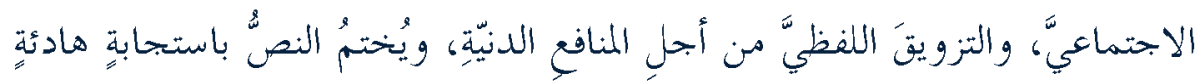

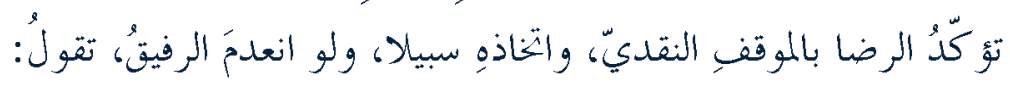

$$
\text { كنتُ و أُنِدُ الشعرَ، وأحكي للقمرْ }
$$

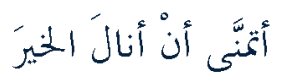

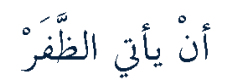

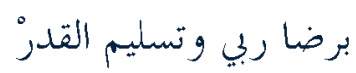

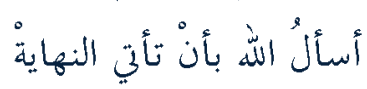

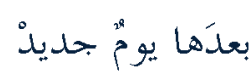

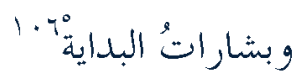

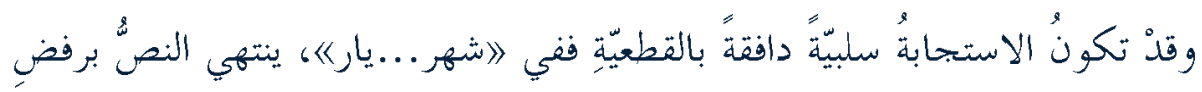

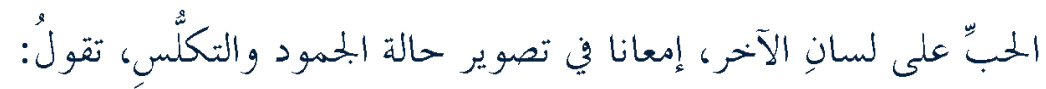

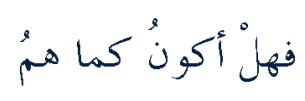

أنا

01 مجلت كليت دار العلوم جامعت الفيوه, العدد 00 إصلاريناير 19. 


$$
\begin{aligned}
& \text { وأنت } \\
& \text { هكذا؟! } \\
& \text { قلبا حنونا دافئا؟ }
\end{aligned}
$$

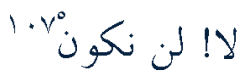

|أخاثة:

استعرضَتْ هذه الدراسةُ النوستالجيا الشعريةً في ديوانِ الشاعرةٍ أسماء الجنوبِيّ، فتعرَّتَ لسياقاتِ هذه النزعةِ في شعرها النابضِ في خضمّ التفاعلاتِ بين

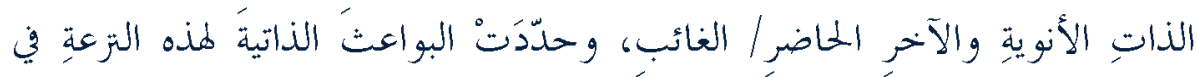

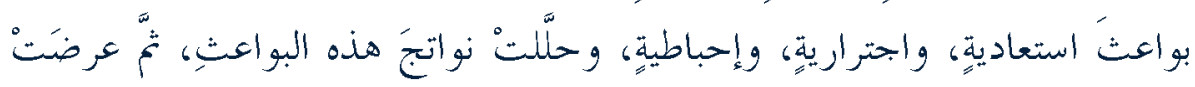

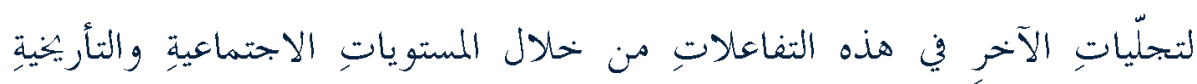

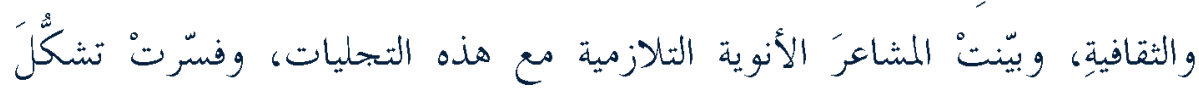

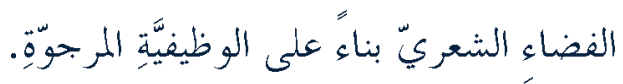

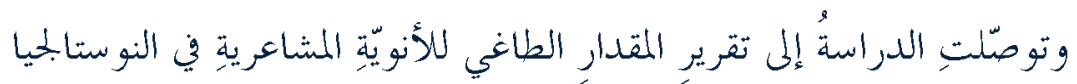

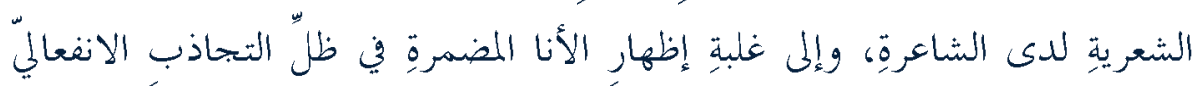

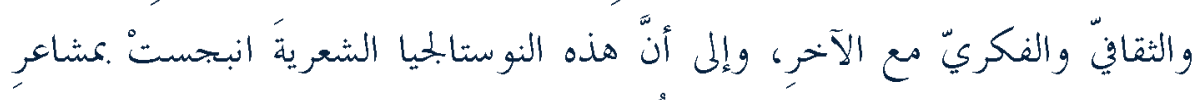

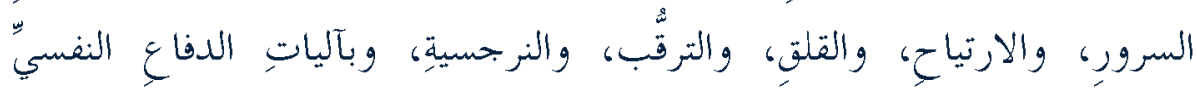

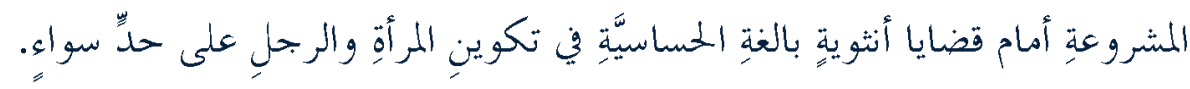


المصادروالئراجع :

1. هذه الأنثى وطن، أسماء الجمنوبي، دار المفردات للنشر والتوزيع، الرياض، الطبعة الأولى، الهب، . $-1 \leqslant r_{0}$

T. استعادة الماضي: دراسات في شعر النهضة، جابر عصفور، داز المدى للثقافة والنشر،

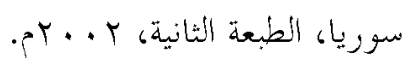

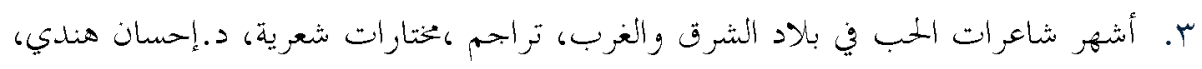

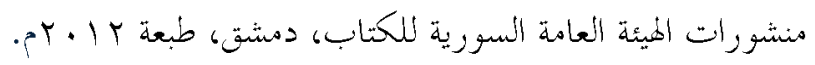

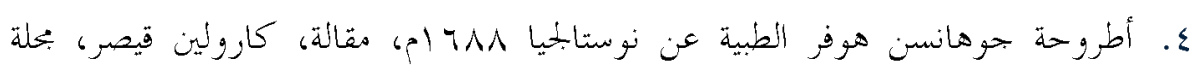

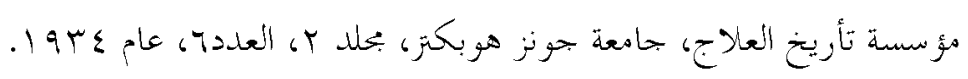

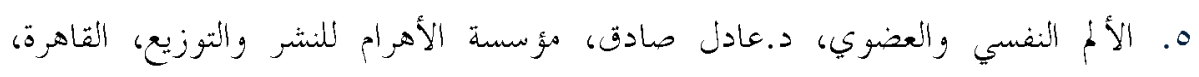
$.619 \lambda 4$

T. آلية التناص في شعر سعد الدين شاهين، جمال علي شهاب، رسالة ماجستير، كلية الآداب

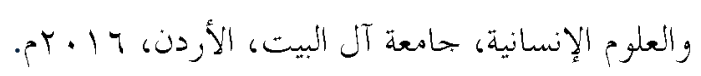

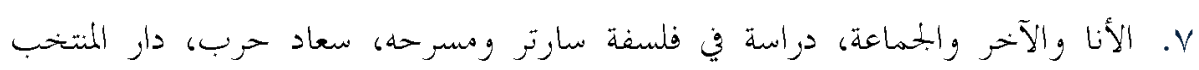

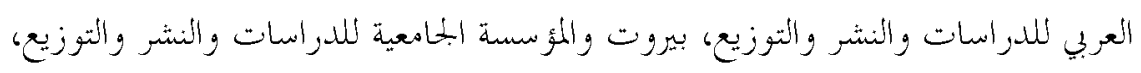

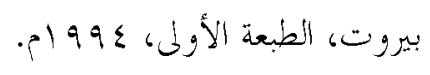

^. الأنا والهوَ، سيجمند فرويد، إشراف: د. يخمد عثمان بناتي، دار الشروق، القاهرة، الطبعة

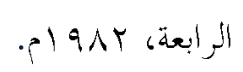

9. الإنسان وعلم النفس، د.عبدالستار إبراهيم، عالم المعرفة، المخلس الوطني للثقافة والفنون

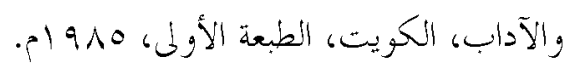

• 1.

$$
\text { طبعة ع 1999 }
$$

11. متثيل الذات في الشعر النسائي المزائري المعاصر، ساجية مغراوي، رسالة دكتوراه،

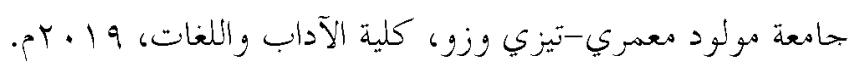


ب ا. . جمالية المراوغة والتوظيف الضمائري للأنا والآخر عبر اللغة الشعرية، دراسة في قصائل مختارة من ديوان هسقط قبي لسمية محنش، حاتم زيدان و د.العيد جلولي، بملة الأثر،

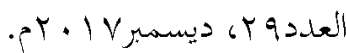

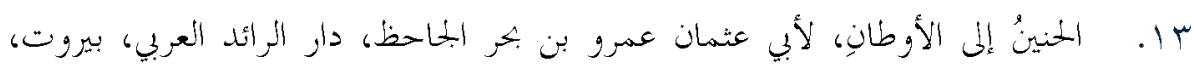

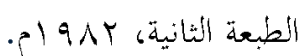

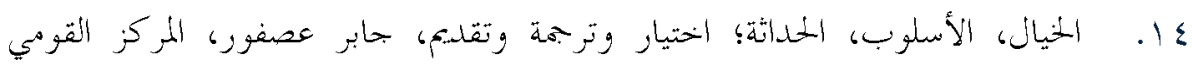

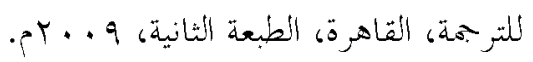

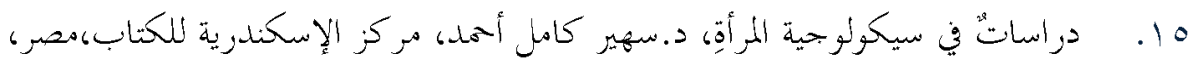
طبعة 19人 1 ا. الذات عينها كآخر، بول ريكور، ترجهة وتقلنيم وتعليق، د.جورج زيناتي، هركز

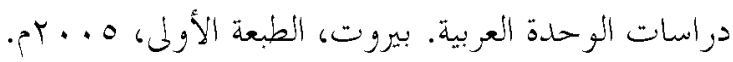

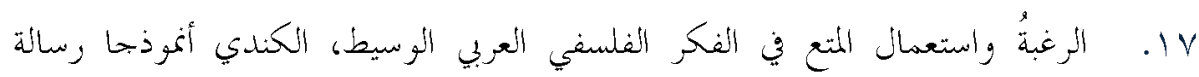

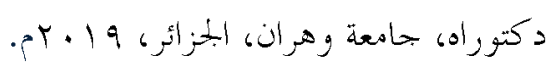

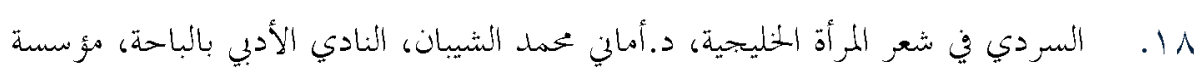
الانتشار العربي، بيروت، الطبعة الأولى.

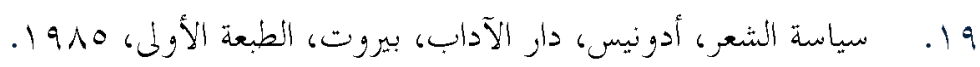
• . . . سيكولوجية المرأة المعاصرة: قضايا هعاصرة. د.ناهل رهزي، مكتبة الأبحلو المصرية،

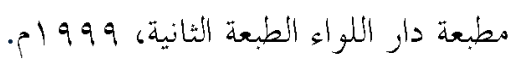

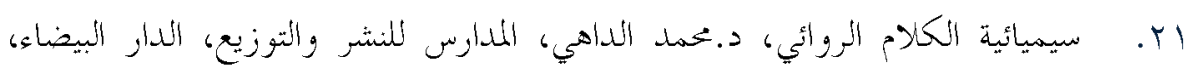

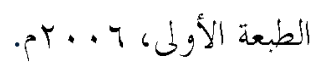

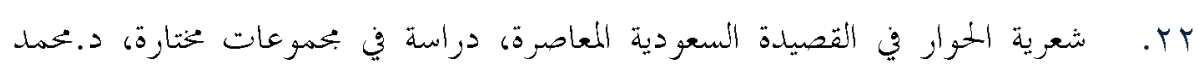

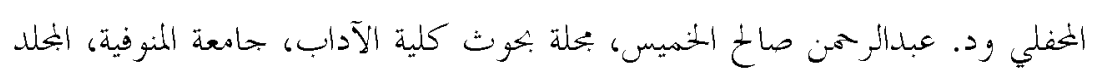

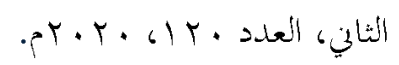

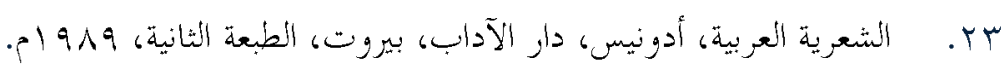

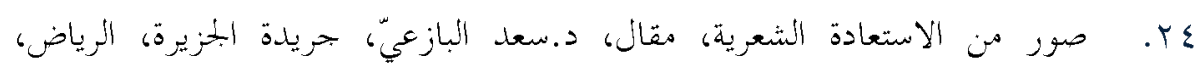
$.199 \mathrm{~N} / \mathrm{V} / \mathrm{r}$ 


\section{النوستالجيا الشعرية بين الأنا والآخر في ديوان (هذه الأنثى وطن) لأسماء الجنويي}

هب. الصورة الفنية في التراث النقدي والبلاغي عند العرب، د.جابر عصفور، المركز الثقافي

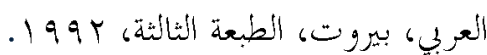

جب. ملم الأسلوب، مبادئه، وإجراءاته، د.صلاح فضل، النادي الأدبي الثقافي بجدة، الطبعة

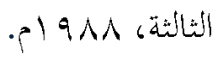

عV . rV

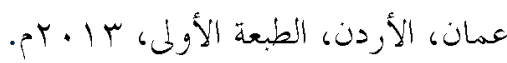

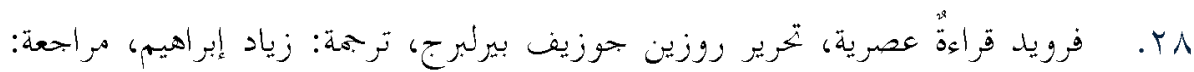

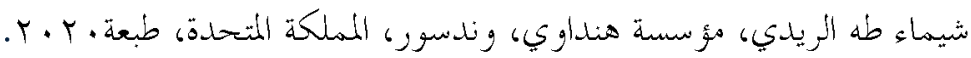

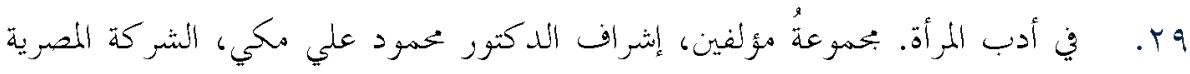

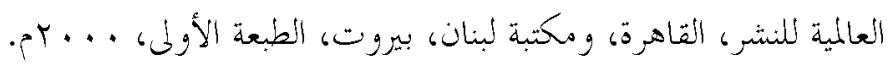
• ب. . هظاهر النوستالجيا في شعر امرئ القيس، عزت إبراهيمي وصديقة جعفري نزاد، بحلة

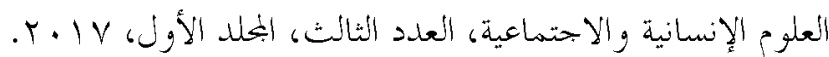

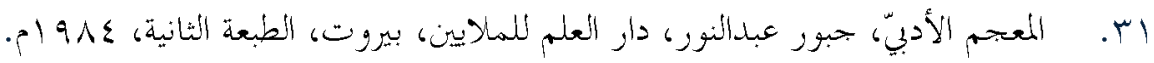

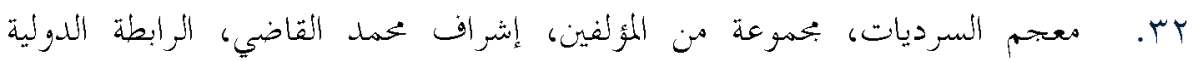

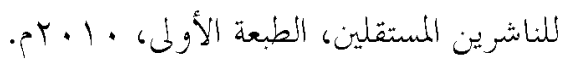
بr. معجم المصطلحات الأدبية، إعداد إبراهيم فتحي، المؤسسة العربية للناشرين المتحدين،

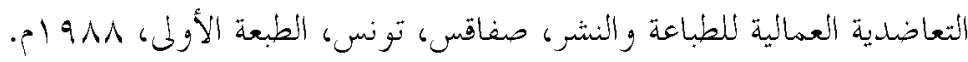
ع ب. معجم المصطلحات العربية في اللغة والأدب، بمابي وهبة وكامل المهندس، مكتبة

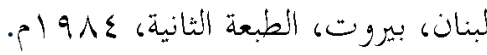
هم. هعجم مصطلحات الطب النفسي، إعداد: لطفي الشربيني، مراجعة: د.عادل صادق،

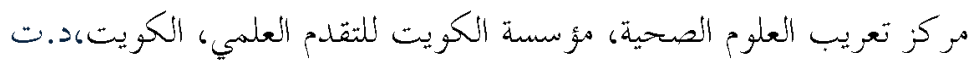
جس. المورد الحديث، قاموس إنكليزي عربي، منير البعلبكي ود.رمزي البعلبكي، دار العلم

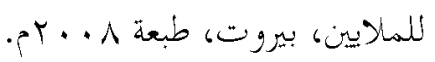
YV

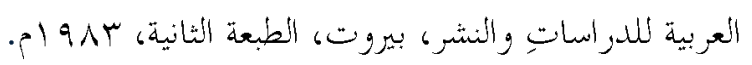


入 ب. مقل الأفكار الأدبية، أدريان هارينو، ترجهة: محمد الرامي، مراجعة وتقلديم: سعيد علوش، المر كز القوهي للترجة، القاهرة، الطبعة الأولى، A + . بم.

جوب. نوستالميا، د.عبدالرحمن الندلة، مقال، بحلة فكر الثقافية، الرياض، العدد الثلاتون،

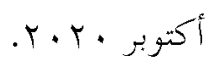

\section{الهوامش والإحالات}

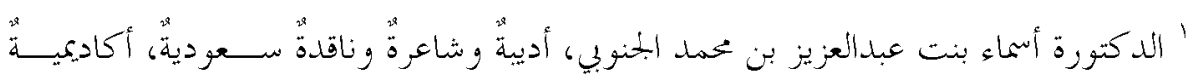

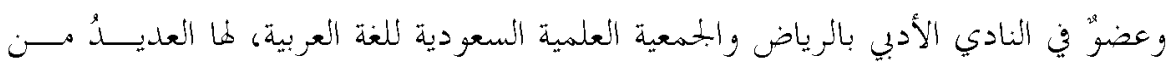

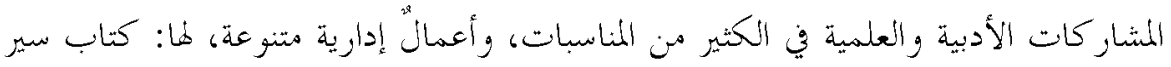
الشعر الذاتية في الأدب العربي، ومن البحوث: أدب رسم الذات في المملكاكة، والروايــة في

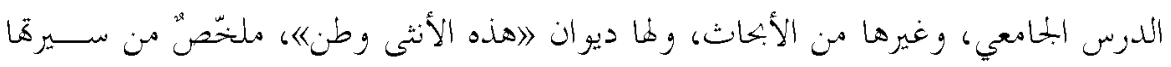
الشخصية بخط يدها.

ז'انظر : المورد المحديث، قاموس إنكليزي عربي، هنير البعلكي ود.رمزي البعلبكي، دار العلم

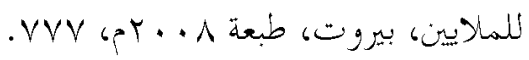

` انظر : دعجم معطلحات الطب النفسي، إعداد: لطفي الشربيني، مراجعة: د.عادل صادق،

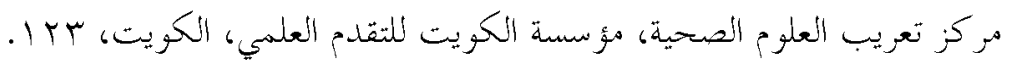

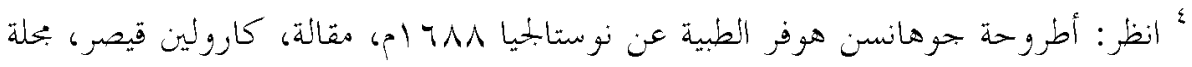

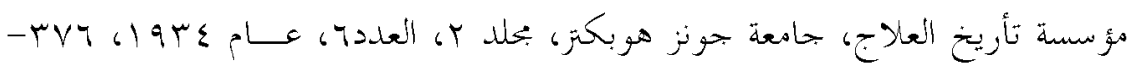
. एq

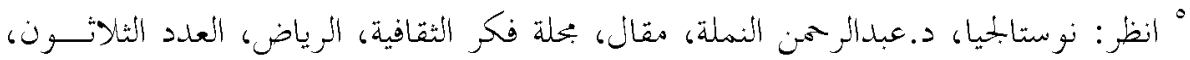

$$
\begin{aligned}
& \text { أكتوبر . . . TV، }
\end{aligned}
$$

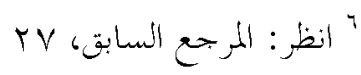

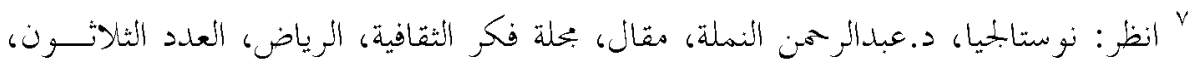

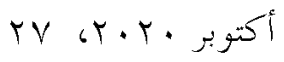

^ انظر : الألم النفسي والعضوي، د.عادل صادق، هؤسسة الأهرام للنشر والتوزيع، القــاهرة،

$176919 \wedge 7$ 
9 انظر : هظاهر النو ستالجيا في شعر امرئ الفيس، عزت إبراهيمي وصديقة جعفري نزاد، بحلة

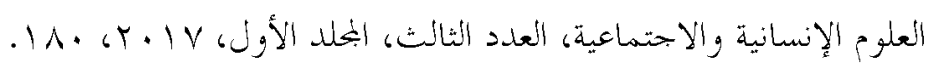

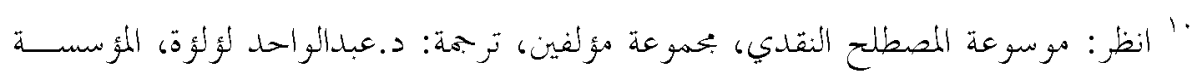

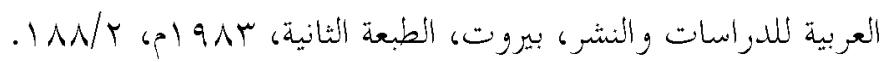

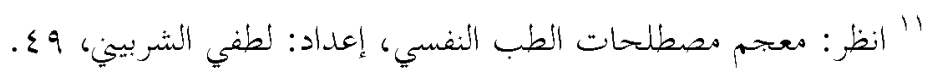

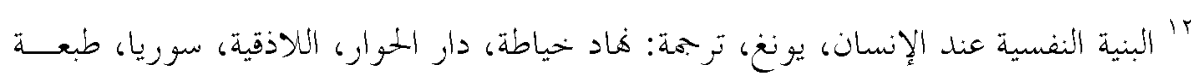
61995

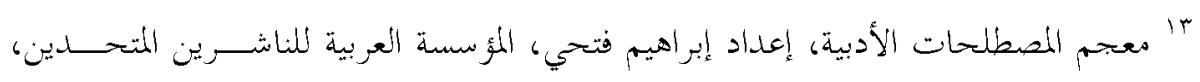
التعاضدية العمالية للطباعة و النشر، صفاقس، تونس، الطبعة الأولى،

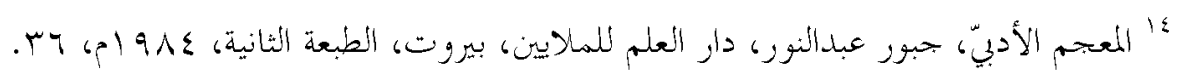
10

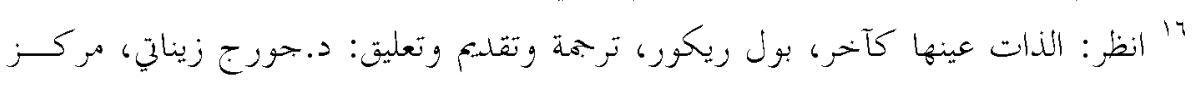

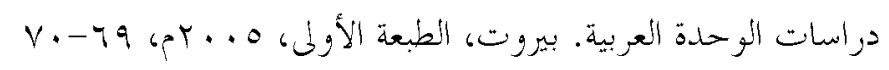

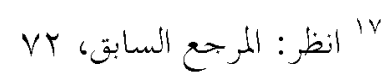
1ا جمالية المراوغة والتوظيف الضمائري للأنا والآخر عبر اللغة الشعرية، دراسة في قصائلَ مختارةٍ

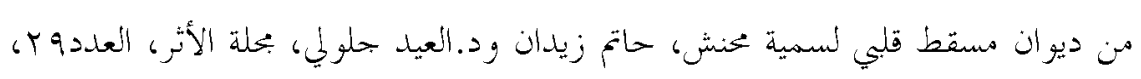

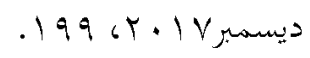

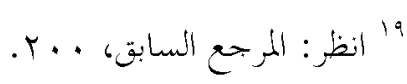

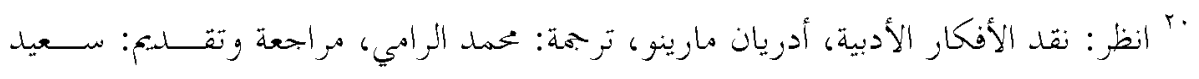

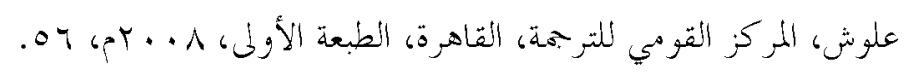

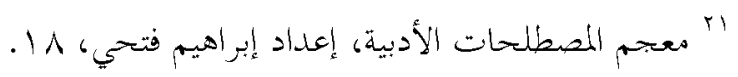

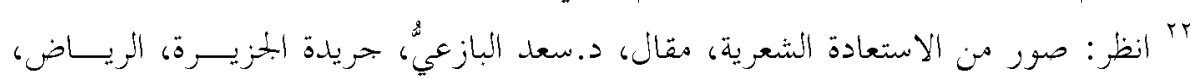

$$
.199 \mathrm{~N} / \mathrm{V} / \mathrm{Tr}
$$

بr انظر الرغبة واستعمال المتع في الفكر الفلسفي العربي الوسيط، الكندي أنموذجسـا، رزاق

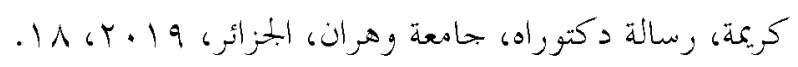




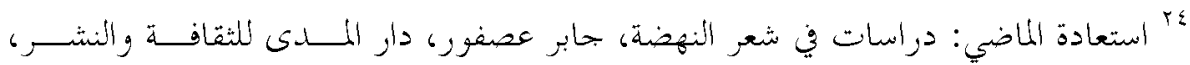

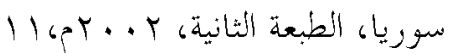

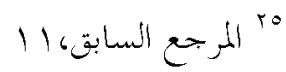

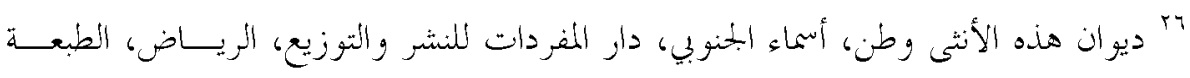
الأولى،

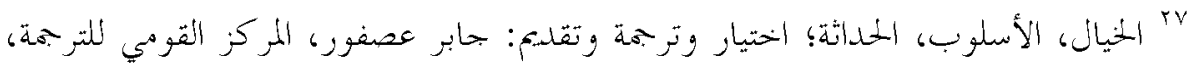

القاهرة، الطبعة الثانية، و +. . بام، 9.

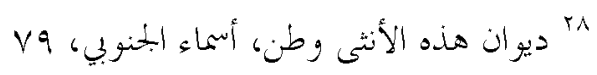
| |

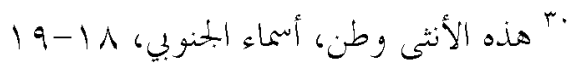

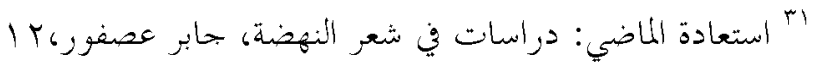

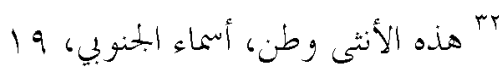

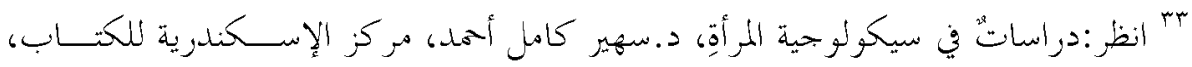

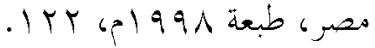

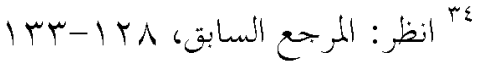

هr انظر : سيكولوجية المرأة المعاصرة: قضايا معاصرة، د.ناهل رمزي، مكتبة الأبخلو المصــرية،

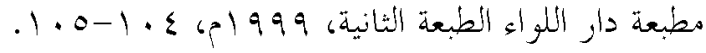

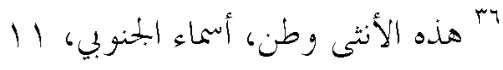

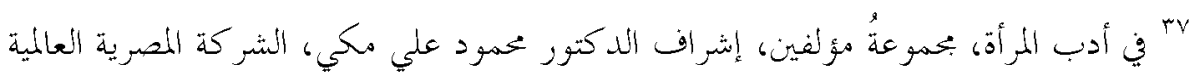

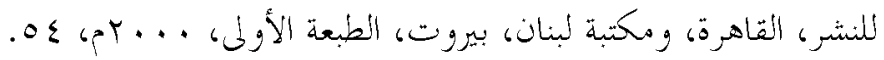

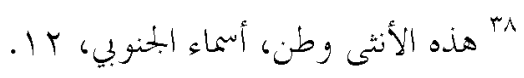

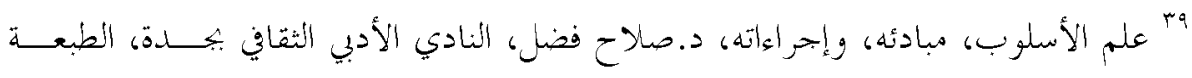
Trt g)

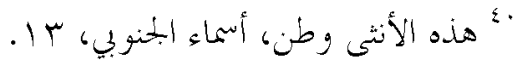


أ شعرية الحوار في القصيدة السعودية المعاصرة، دراسة في مبموعات مختارة، د.محمد المخفلي،

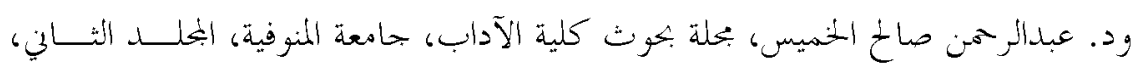

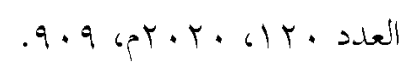

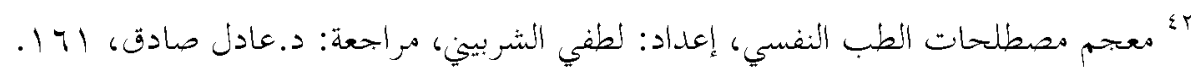

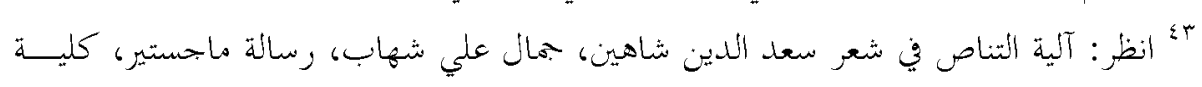

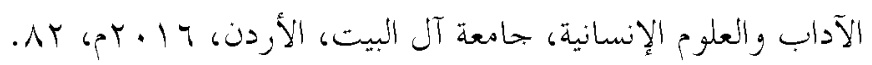

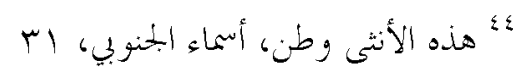

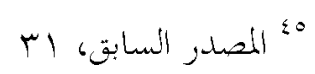
4؛ الأنا والآخر والمحاعة، دراسة في فلسفة سارتر وهسر حه، سعاد حرب، دار المنتخب العربي

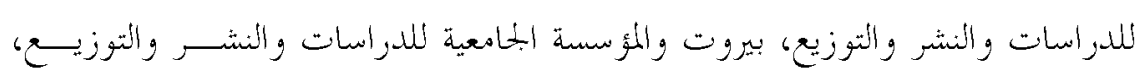

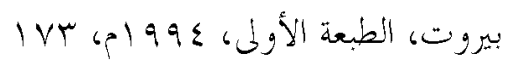

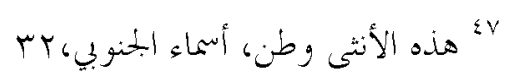

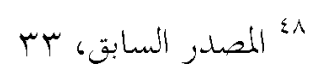

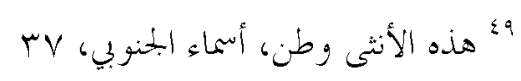

•انظر : الصورة الفنية في التراث النقدي والبلاغي عند العرب، د.بابر عصفور، المركز الثنافي

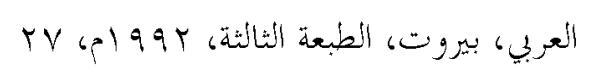

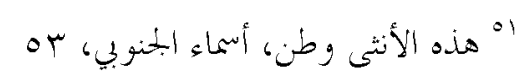

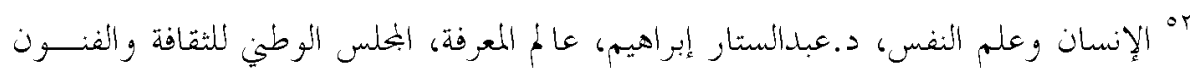

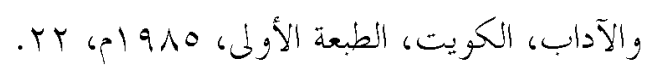

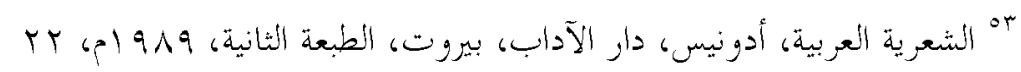

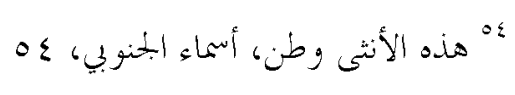

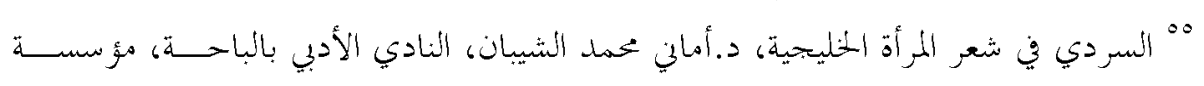

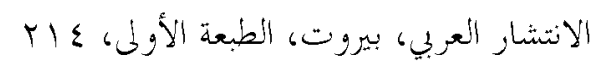

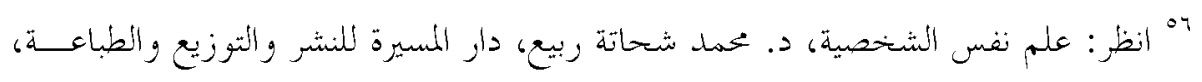

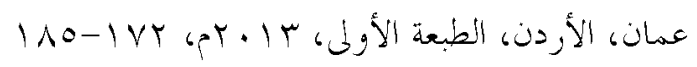




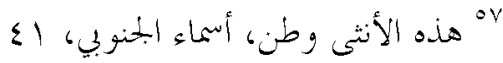

$$
\begin{aligned}
& \text { 10 علم نفس الشخصية، د. محمل شحاتة ربيع، . ، } 17 .
\end{aligned}
$$

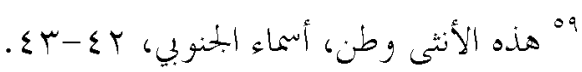

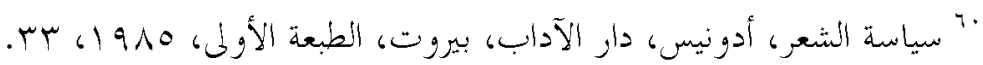

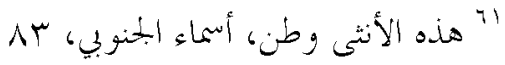

$$
\begin{aligned}
& \text { A }
\end{aligned}
$$

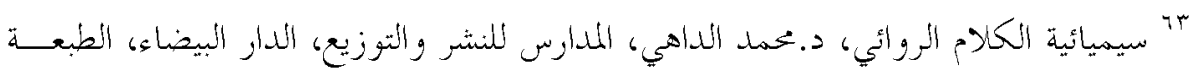

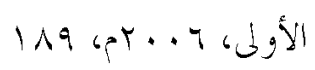

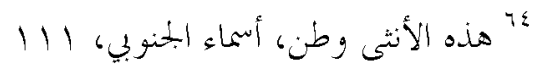

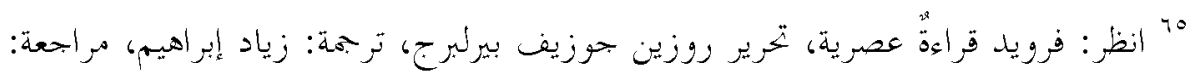

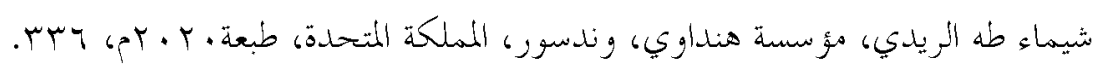

$$
\begin{aligned}
& \text { 1Y هذه الأنثى وطن، أسماء الجنوبي، } 111 \\
& \text { TV }
\end{aligned}
$$

شا الأنا والهوَ، سيجمند فرويلد، إثراف، د. محمد عثمان بناتي، دار الشروق، القاهرة، الطبعة

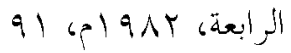

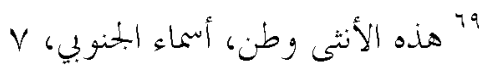

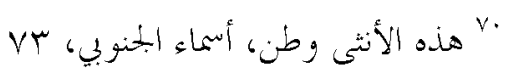

$$
\begin{aligned}
& \text { النظر : علم نفس الشخصية، د. محمد شحاتة ربيع، }
\end{aligned}
$$

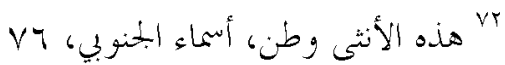

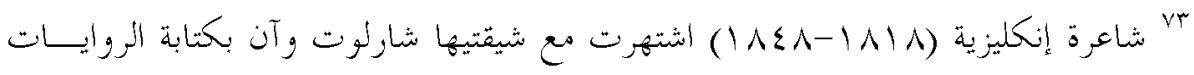

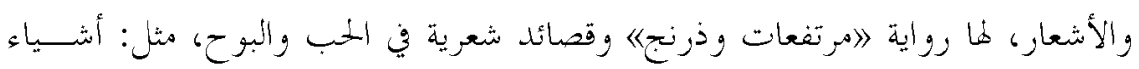

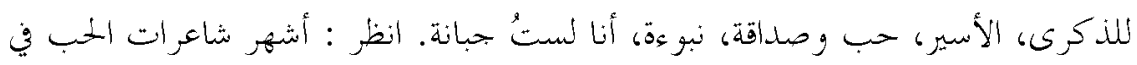

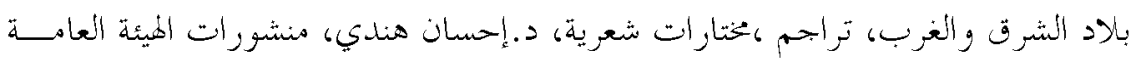

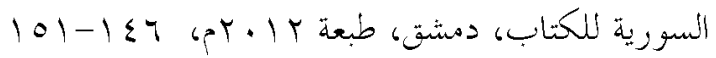

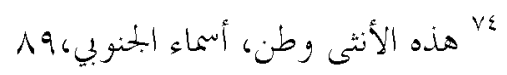




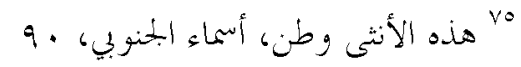

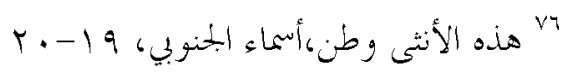

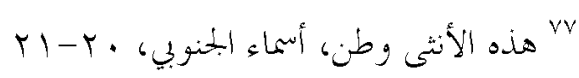

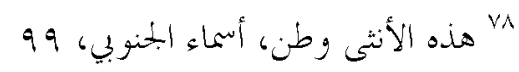

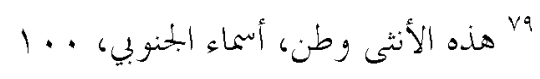

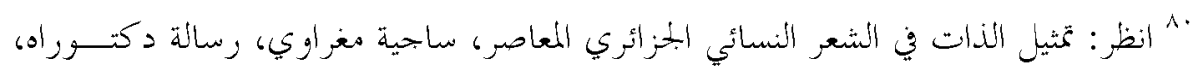

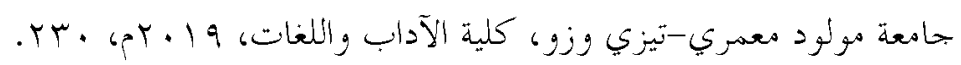

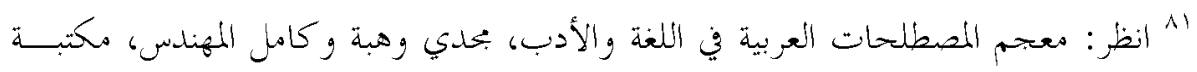

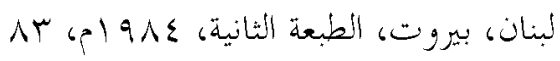

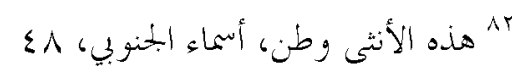

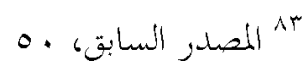

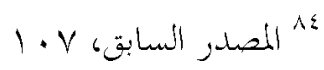

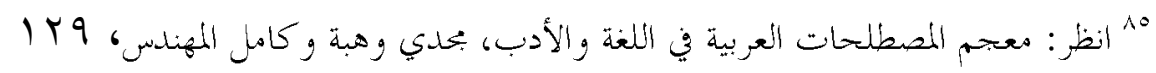

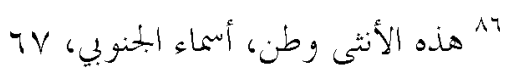

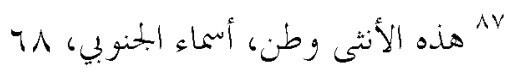

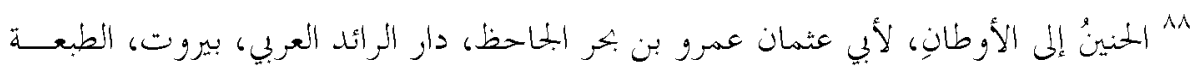

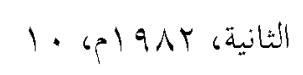

$$
\text { 99 هذه هذه الأنثى وطن، أسماء المنوبي، } 79
$$

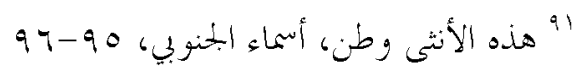

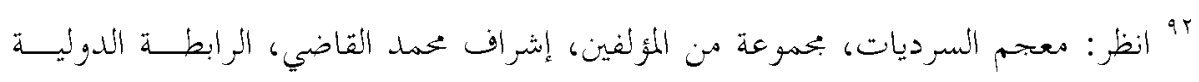

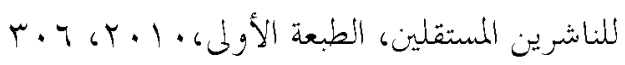

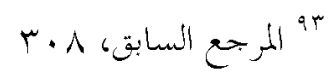

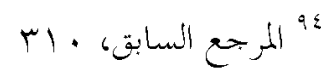

مجلت كليت دار العلوه جامعت الفيوه, العدد 00 إصداريناير 19.r 
هو انظر : جمالية المراوغة والتوظيف الضمائري للأنا والآخر عبر اللغة الشعرية، دراسة في قصائلَ

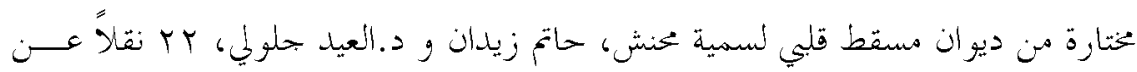
الرغبة والفلسفة: ملخحل إلى قراءة دولوز غوتاري، محمد آيت حنا، دار توبقال للنشــر، bاك

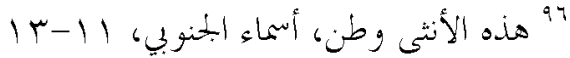

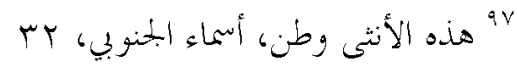

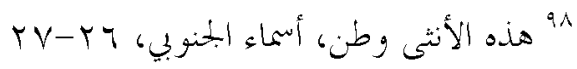

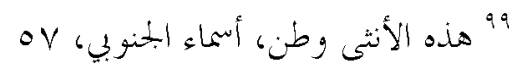

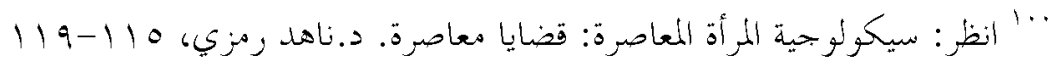

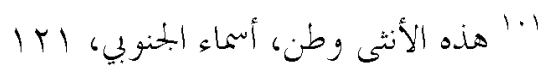

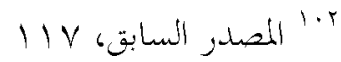

ب." انظر : معجم مصطلحات الطب النفسي، إعداد: لطفي الشربيني، مرأجعة: د.عادل صادق،

$$
109-101
$$

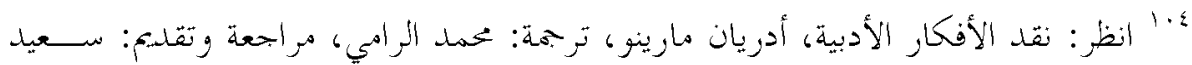

$$
\begin{aligned}
& \text { علوش، }
\end{aligned}
$$

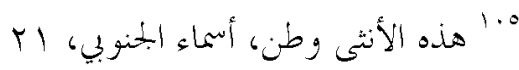

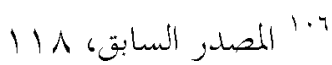

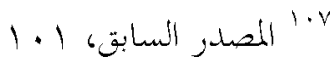

